\title{
Emergency Response Monitoring Activities and Environmental Impact of the K-Reactor Aqueous Tritium Release of December $1991^{(U)}$
}

D. M. Hamby, R. P. Addis, D. M. Beals, J. R. Cadieux, W. H. Cariton, D. L. Dunn, G. Hall, D. W. Hayes, R. Lorenzo M. V. Kantelo and R. W. Taylor

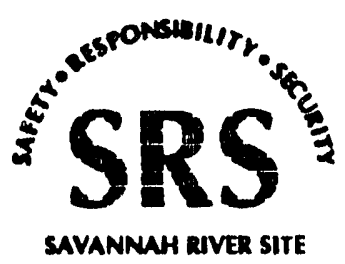

Prepared for the U. S. Department of Energy under contract no. DE-AC09-89SR18035 
WSRC-RP--92-186

DE92 014364

EMERGENCY RESPONSE MONITORING ACTIVITIES AND

ENVIRONMENTAL IMPACT OF THE K-REACTOR AQUEOUS

TRITIUM RELEASE OF DECEMBER 1991 (U)

D.M. Hamby

R.P. Addis

D.M. Beals

J.R. Cadieux

W.H. Carlton

D.L. Dunn

G. Hall

D.W. Hayes

R. Lorenz

M.V. Kantelo

R.W. Taylor

Publication Date: February 7, 1992

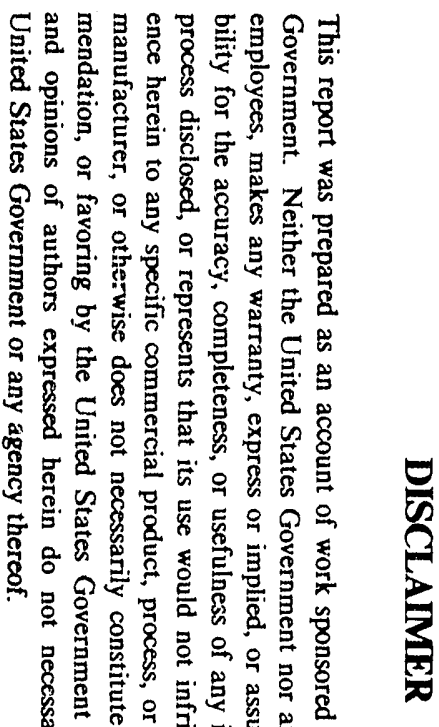

\section{Approved By:}

A.L. Boni, Manager ETS

J.D. Heffner, Manager EMS

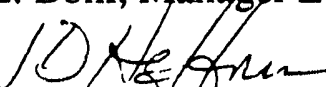

Westinghouse Savannah River Company Savannah River Site

Aiken, SC 29808 
Summary $\ldots \ldots \ldots \ldots \ldots \ldots \ldots \ldots \ldots \ldots \ldots \ldots \ldots \ldots \ldots \ldots \ldots \ldots \ldots \ldots$

Introduction $\ldots \ldots \ldots \ldots \ldots \ldots \ldots \ldots \ldots \ldots \ldots \ldots \ldots \ldots \ldots \ldots \ldots \ldots \ldots$

Emergency Response $\ldots \ldots \ldots \ldots \ldots \ldots \ldots \ldots \ldots \ldots \ldots \ldots \ldots \ldots \ldots \ldots \ldots \ldots$

Source Term

Transport Time

Maximum Concentrations in the Savannah River

Dose Estimation

Sample Collection $\ldots \ldots \ldots \ldots \ldots \ldots \ldots \ldots \ldots \ldots \ldots \ldots \ldots \ldots \ldots \ldots$

Analytical Results and Discussion .......................... 4

Observed Transport Time

Estimation of Source Term

Health Impacts . . . . . . . . . . . . . . . . . . . . . . . . . . 6

Maximum Drinking-Water Dose

Maximum Dose from the Consumption of Aquatic Species

Average Individual and Population Dose

EPA Drinking Water Standard

Dose to Aquatic Biota

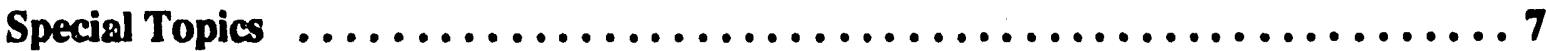
Abercorn Creek/Port Wentworth Intake

The Savannah River Estuary

Acknowledgements $\ldots \ldots \ldots \ldots \ldots \ldots \ldots \ldots \ldots \ldots \ldots \ldots \ldots \ldots \ldots \ldots \ldots$

References $\ldots \ldots \ldots \ldots \ldots \ldots \ldots \ldots \ldots \ldots \ldots \ldots \ldots \ldots \ldots \ldots \ldots \ldots \ldots \ldots$

Appendix A - Sampling Locations and Maps

Table A1. Sampling locations on the Savannah River

Figure A1. Map of SRS to Atlantic Ocean

Figure A2. Map of area near Beaufort-Jasper and Port Wentworth

Figure A3. Map of the Savannah River estuary

Appendix B - Analytical Methods and Data Summary

Figure B1. Comparison of EMS \& ETS monitoring data

Figure B2. Comparison of GDNR \& ETS monitoring data

Figure B3. Concentrations in Steel Creek

Figure B4. Concentrations at Highway 301

Figure B5. Concentrations at Becks Ferry

Figure B6. Concentrations at Abercorn Creek 
Figure B7. Concentrations at Beaufort-Jasper lift station

Figure B8. Concentrations at Beaufort-Jasper intake

Figure B9. Concentrations near Fort Pulaski

Figure B10. Concentrations at Priest Landing

Figure B11. Concentrations in Savannah River with WINDS arrival predictions

Figure B12. Historical weekly average of tritium concentrations in the Savannah River

Figure B13. Estimated monthly maximum tritium dose via drinking water for 1991

Table B1. Steel Creek survey

Table B2. Highway 301 survey

Table B3. Becks Ferry survey

Table B4. Beaufort-Jasper canal survey before lift station

Table B5. Beaufort-Jasper lift station survey

Table B6. Beaufort-Jasper canal survey after lift station

Table B7. Beaufort-Jasper plant intake survey

Table B8. Beaufort-Jasper water treatment plant survey

Table B9. Abercorn Creek survey

Table B10. Port Wentworth water treatment plant survey

Table B11. Estuarine study

Table B12. Estuarine survey

Table B13. Daily average tritium concentrations in Savannah River

Table B14. Tritium transported in the Savannah River past Highway 301

Appendix C - Quality Assurance

Figure C1. Typical uncertainties in the LSC

Figure C2. Spike results

Figure C3. Blank results

Appendix D - Tritium Transport in the Savannah River

Figure D1. December 25, 1991

Figure D2. December 26-27, 1991

Figure D3. December 31, 1991 - January 1, 1992

Figure D4. January 2-3, 1992

Figure D5. January $9-10,1992$ 


\title{
Emergency Response Monitoring Activities and Environmental Impact of the K-Reactor Aqueous Tritium Release of December $1991^{(c)}$
}

\author{
D. M. Hamby, R.P. Addis, D. M. Beals, J. R. Cadieux, W. H. Carlton, D .L. Dunn, G. Hall, \\ D.W. Hayes, R. Lorenz, M. V. Kantelo and R.W. Taylor
}

Westinghouse Savannah River Company

Savannah River Site

Aiken, SC 29808

\section{Summary}

Approximately 150 gallons of tritiated water leaked from one of the $\mathrm{K}$-Reactor heat exchangers between December 22 and December 25, 1991. Upon notification, the Environmental Technology Section (ETS) activated its emergency response team to provide predictions of river concentrations, transport times, and radiological effects to downstream water users. Additionally, within a few days of the release, ETS and the Environmental Monitoring Section (EMS) began a comprehensive program to collect and analyze surface water samples from SRS down to the Savannah River estuary. The TRAC mobile laboratory was deployed to the Beaufort-Jasper water treatment planit to provide initial analyses for downriver water samples.

Elevated tritium concentrations in the Savannah River at Highway 301 were first detected on December 26, 1991. Further downstream at Becks Ferry, adjacent to the intake canal for the Beaufort-Jasper water treatment plant, elevated tritium concentrations were first detected during the morning of December 28, 1991. Later that afternoon tritium concentrations began to rise at Abercorn Creek, where the lift station for the Port Wentworth water treatment plant is located.

Concentrations at each location reached their peak about 30 hours after arrival of the leading edge. The maximum measured concentration at Highway 301 was $66.9 \mathrm{pCi} / \mathrm{mL}$. Daily average river flow rates and measured tritium concentrations were utilized to determine the daily amounts of tritium transported past the Highway 301 bridge and the Beaufort-Jasper intake canal. From these data, it was estimated that approximately 5700 curies of tritium were released from the leaking heat exchanger to the Savannah River.

The maximum dose to a hypothetical indiviaual, one who consumed 2 liters of water per day at Highway 301 for the duration of plume passage, would have received a dose from drinking water of approximately $0.035 \mathrm{mrem}$. This dose is more than 100 times smaller than the E.PA drinking water standard of $4 \mathrm{mrem} / \mathrm{yr}$. Average individual doses to users of the Beaufort-Jasper and Port Wentworth domestic water supplies are 0.0048 and $0.015 \mathrm{mrem}$, respectively.

\section{Introduction}

At the end of 1991, an unplanned release of tritium occurred at $\mathrm{K}$ Reactor. The tritium was released between December 22 and December 25, 1991 through the K-Area secondary cooling water discharge in the form of tritiated heavy water (primary cooling water). Samples of reactor discharge water taken twice per day showed no evidence of leakage up to the moming of December 22. A sample of discharge water collected on the evening of December 22, however, indicated elevated concentrations of tritium upon later analysis. Analysis of samples collected the following day were inconsistent and the elevated concentrations were not 
confirmed until December 24 . The leak was positively identified and isolated on December 25.

Released tritium was tracked and measured as it traveled from the cooling canal into Pen Branch, through the Savannah River swamp, past the mouth of Steel Creek, and down the Savannah River, Figure A1. Two Savannah River Site environmental groups, SRL's Environmental Technology Section (ETS) and ESH\&QA's Environmental Monitoring Section (EMS) jointly developed and executed sampling programs to monitor the movement of tritium from SRS to the Atlantic Ocean. ETS results were in good agreement with EMS results from water samples taken at Highway 301, Becks Ferry, and Abercom Creek (Figure B1).

Georgia and South Carolina environmental agencies were also involved in sampling Savannah River water. The Georgia Department of Natural Resources (GDNR) and the South Carolina Department of Health and Environmental Control (SCDHEC) conducted independen impling and analysis programs. Results of GDNR surve! vere also in good agreement with SRS results. Figure B2 shows a comparison of GDNR and ETS concentration measurements. Data from SCDHEC were unavailable at the time of this writing.

The Beaufort-Jasper Water and Sewer Authority shut down its river water intake pumps for 9 days while the tritium plume moved further downstream. Because Port Wentworth's water supply, Abercorn Creek, is influenced by tides, the Port Wentworth water treatment plant managed its pumping schedule to minimize the amount of tritium that entered their system. Some industries using water from the Port Wentworth system ceased operations for several days in response to the increased tritium concentrations in the Savannah River.

\section{Emergency Response}

At approximately 2:00 pm on December 25, 1991, two members of the ETS reported to the Emergency Operating Facility in Building 703-A. That afternoon the following tasks were accomplished: 1) estimated source term, 2) estimated transport time, 3) estimated the maximum tritium concentration in the Savannah River, and 4) estimated maximum radiation dose and its impact.

\section{Source Term}

The source term was estimated to be 7500 curies. The assumptions used for the estimation in the initial response phase of the incident were as follows:

- The release is assumed to have begun at $12: 30 \mathrm{pm}$ on December 22, 1991 (midway between routine sampling times) and terminated at 4:10 am on December 25, 1991, lasting approximately sixty-four hours.

- The average tritium concentration in Pen Branch, 2600 DCi/mL, from 10:20 am, December 23, 1991 until 8:00 am on December 25, 1991, was assumed to be representative of the entire release. The value is based on water collected by an EMS continuous sampler located on Pen Branch.

- It was assumed that the flow rate of Pen Branch at the sample point was $440 \mathrm{ft} 3 / \mathrm{sec}$ for the entire sample period. This flow rate was based on measurements from the U.S. Geological Survey (USGS) monitoring station located at Pen Branch.

The underlined values above were used to calculate the initial source term estimate:

$$
\begin{aligned}
& (64 \mathrm{hr})\left(2600 \frac{\mathrm{pCi}}{\mathrm{mL}}\right)\left(440 \frac{\mathrm{ft}^{3}}{\mathrm{~s}}\right)\left(10-12 \frac{\mathrm{ci}}{\mathrm{pCi}}\right) \\
& \left(28.32 \frac{\mathrm{L}}{\mathrm{ft}^{3}}\right)\left(1000 \frac{\mathrm{mL}}{\mathrm{L}}\right)\left(3600 \frac{\mathrm{s}}{\mathrm{hr}}\right)=7500 \mathrm{Ci}
\end{aligned}
$$

\section{Transport Time}

The WIND System Stream Transport Model was used to predict downstream arrival times of the tritiated water released from $\mathrm{K}$ Reactor. The code was executed assuming that all the tritium was released at 12:30 pm, December 22 , 1991. The predicted travel and arrival times are shown below. 
Predictions of peak travel/arrival time of tritium released from $\mathrm{K}$ Reactor.

\begin{tabular}{|lllll|}
\hline Location & \multicolumn{2}{c}{$\begin{array}{c}\text { Predicted Peak } \\
\text { Travel Time }\end{array}$} & \multicolumn{2}{c|}{$\begin{array}{l}\text { Predicted Peak } \\
\text { Arrival Time }\end{array}$} \\
\hline Pen Branch at Road A & 6 hrs & 0 mins & $6: 30 \mathrm{pm}$ & Dec. 22, 1991 \\
Savannah River at: & & & & \\
Steel Creek & 3 days & 11 hrs 30 mins & $12: 00 \mathrm{am}$ & Dec. 26, 1991 \\
Highway 301 & 4 days & $2 \mathrm{hrs} 45 \mathrm{mins}$ & $3: 15 \mathrm{pm}$ & Dec. 26, 1991 \\
Beaufort-Jasper Intake & 6 days & $8 \mathrm{hrs} 0$ mins & $8: 30 \mathrm{pm}$ & Dec. 28, 1991 \\
\hline
\end{tabular}

\section{Maximum Concentrations in the Savannah River}

The initial prediction of maximum tritium concentration in the Savannah River was obtained by scaling the concentration measured in Pen Branch $(2600 \mathrm{pCi} / \mathrm{mL})$ with the ratio of the Pen Branch flow (440 cfs) and the measured Savannah River flow rate (6700 cfs) at Augusta, Georgia on December 26:

$$
2600 \mathrm{pCi} / \mathrm{ml}\left[6700 \frac{440 \mathrm{cfs}}{6700 \mathrm{cfs}}\right]=170 \mathrm{pCi} / \mathrm{mL}
$$

\section{Dose Estimation}

A conservative estimate of radiation dose to an individual downstream of the SRS was calculated using the LADTAP $\mathrm{XL}$ river flow model. ${ }^{5}$ The maximum individual is assumed to ingest 2 liters of raw river water each day from the Savannah River at a point where complete mixing has occurred. The population dose is calculated based on the consumption of 1 liter of water each day by each of the individuals served by the water treatment facilities at Beaufort-Jasper and Port Wentworth (approximately 65,000 customers). The flow rate of the Savannah River was assumed to be a constant $6700 \mathrm{ft} 3 / \mathrm{sec}$, based on information supplied by the USGS for Augusta, Georgia. Initial estimates of maximum individual and population dose via the drinking water pathway were 0.06 mrem and 1.9 person-rem, respectively. ${ }^{2}$

\section{Sample Collection}

Water samples were collected periodically from bodies of water and two water treatment plants affected by the transport of tritium in route to the Atlantic Ocean. The bodies of water consisted of SRS streams, the Savannah River, the intake canal for the Beaufort-Jasper water treatment plant, Abercorn Creek, and the Savannah River estuary. Beaufort-Jasper and Port Wentworth were the two water treatment plants. The following photograph illustrates sampling at Beck's Ferry boat dock, other sampling locations are described in Table A1, Appendix A. Typical sample sizes ranged from 250 to $500 \mathrm{~mL}$. All bottles used in sampling were rinsed with deionized water prior to use.

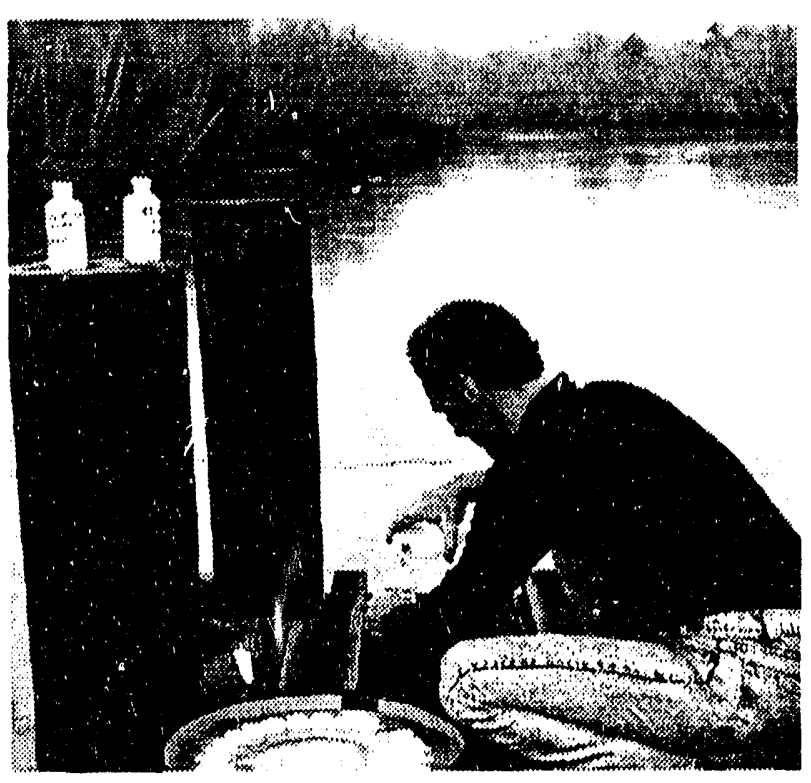

Two techniques were used in sampling. ETS sampling teams collected grab samples (also known as dip samples) by dipping a plastic bottle below the water surface. Many of the grab samples of raw and finished water were collected by personnel from the water treatment plants. The second technique consisted of battery-powcred automatic samplers that collected grab samples at specific time intervals; bottles 
for 24 individual samples are contained in each automatic sampler.

Prior to this study, automatic samplers were located at Stcel Creek and Highway 301 bridge. Each sampler was programmed to collect a grab sample at 6 -hour intervals and combine four successive samples to form a daily composite. During the present study, these samplers and the samplers that were installed down to the estuary were typically programmed to collect an individual grab sample every 60 or 120 minutes. Many locations also had a backup automatic sampler that was programmed to collect a sample midway between the primary sampler's collection interval. This resulted in grab samples being collected at 30 minute intervals.

EMS collected and analyzed daily composite samples from Pen Branch, onsite, Highway 301 and raw and finished water from the Beaufort-Jasper and Port Wentworth water treatment facilities. Additional information on EMS sampling is given in the Special Topics section.

Water samples were retrieved from automatic samplers by sampling teams several times daily. Steel Creek and Highway 301 samples were delivered to SRL for analysis in ETS laboratories. Samples from the other locations were delivered to the TRAC mobile laboratory while it was deployed at the Beaufort-Jasper water tratment plant at Chelsea, South Carolina, from December 29, 1991, to January 15, 1992. Aliquots of selected samples were taken for screening analysis aboard the TRAC thereby expediting turn-around times of crucial measurements. The remaining portion of these samples and all other samples were delivered to the ETS laboratories for analysis.

\section{Analytical Results and Discussions}

Tritium concentrations for all sampling locations are summarized in Appendix B. Also included in the Appendix is a discussion of analytical methods (also see Reference 1) used in ETS laboratories and the TRAC vehicle. Appendix $C$ contains quality control data prepared during the analyses.

The peak tritium concentration at Steel Creek, 1350 $\mathrm{pCi} / \mathrm{mL}$, occurred during the morning of December 28 (Figure B3 and Table B1). Peak tritium concentrations at Highway 301 exceeded $60 \mathrm{pCi} / \mathrm{mL}$ on December 28 and then generally declined daily towards pre-release concentrations (Figure B4 and Table B2). Tritium released from K-Reactor essentially had passed the Highway 301 bridge by January 10 .
As shown in Figures B5 and B6, tritium concentrations greater than $50 \mathrm{pCi} / \mathrm{mL}$ were measured on December 30 in the Savannah River near both water treatment plants. The concentrations in this part of the river were about $20 \%$ lower than the concentrations at the Highway 301 bridge. This is principally due to surface water inflow from streams between these locations.

The Beaufort-Jasper water treatment plant stopped pumping water from the Savannah River at approximately 6:00 am on December 28. Grab samples were collected in the Savannah River at Becks Ferry (Table B3) and from the intake canai leading to the Beaufort-Jasper lift stat on. The maximum tritium concentration in the canal near the Savannah River on Jaruary 1,1992 was $30 \mathrm{pCi} / \mathrm{mL}$ (Table B4). Concentrations had decreased to about $15 \mathrm{pr}: \mathrm{i} / \mathrm{mL}$ by the time the Beaufort-Jasper water treatment plant. resurned pumping January 6 . Water containing approximately 15 $\mathrm{pCi} / \mathrm{mL}$ moved down the canal and through the lift station on January 7 (Figure B7).

Grab samples were collected at the lift station (Table B5) and in the canal between the lift station and the treatment plant beginnirig January 7 (Table B6). The data show the parcel of tritiated water moving down the canal, reaching the receiving pond adjacent to the treatment plant by January 14. The iritium concentration at the pond entrance was half that measiured at the lift station due to dilution. Samples collected at the plant intake (Figure B8 and Table B7) confirm that the tritiated water did not reach the Beaufort-Jasper treatment plant until January 15 , at a concentration of five to seven $\mathrm{pCi} / \mathrm{mL}$. Treatment plant personnel collected samples of the raw and finished drinking water at Beaufort-Jasper. As shown in Table B8 the activity of the drinking water increased slightly after January 15.

Sampling in the Port Wentworth water treatment plant system was not as extensive as at Beaufort-Jasper. The fluctuations in tritium soncentrations in Abercorn Creek (Figure B6 and Table B9) are due to tidal effects as discussed in the Special Topics section. The only other samples collected near Port Wentworth were raw and finished water from the treatment plant. Tritium concentrations were elevated in both the raw and finished water from December 30, 1991 through January 7, 1992 (Table B10). As the river's tritium concentration returned to lower values, so did the tritium concentrations in Port Wentworth raw and finished water.

Sampling was also conducted at various locations in the Savannah River estuary. ETS installed samplers at Fort Pulaski, Priest Landing, and $S_{k}$ : Laway Institute. Measured 
concentrations are shown in Figures B9 and B10 and Table B11. Only within the Savannah River itself did tritium concentrations exceed $20 \mathrm{pCi} / \mathrm{mL}$ (Table B12). See the section on Special Topics for further discussion of these results.

\section{Observed Transport Time}

The WIND System Stream Transport computer code was initially used to predict arrival times at key locations downstream of the SRS. The table below provides original predictions and actual arrival times at locations downstream of the SRS. Concentrations in the Savannah River at Highway 301, Beaufort-Jasper, and Port Wentworth are plotted in Figure B11 along with predicted peak arrival times. Peak concentrations appeared more than a day after predicted, but predictions were generated assuming a short release at the earliest time possible, December 22, 1991, at 12:30 pm. A color-coded graphic representation of the tritium plume in the Savannah River during the period December 25, 1991 through January 10, 1992 is presented as Appendix D.

Predicted and observed tritium plume arrival times in the Savannah River.

\begin{tabular}{|llll|}
\hline & & \multicolumn{2}{c|}{ Arrival Time } \\
\cline { 2 - 5 } Location & $\begin{array}{l}\text { Predicted } \\
\text { Peak }\end{array}$ & $\begin{array}{l}\text { Observed } \\
\text { Leading Edge }\end{array}$ & $\begin{array}{l}\text { Observed } \\
\text { Peak }\end{array}$ \\
\hline In Savannah River at: & & & \\
Highway 301 & $3: 15$ pm, Dec. 26 & $1: 10$ am, Dec. 26 & 9:30 pm, Dec. 27 \\
Beaufort-Jasper Intake & $\begin{array}{l}8: 30 \text { pm, Dec. 28 } \\
\text { Port Wentworth Intake }\end{array}$ & $\begin{array}{l}10: 30 \text { am, Dec. 28 } \\
\text { 3:15 am, Dec. 29 }\end{array}$ & $\begin{array}{l}\text { 1:00 pm, Dec. 28 } \\
\text { 5:30 pm, Dec. 30 }\end{array}$ \\
\hline
\end{tabular}

\section{Estimation of Source Term}

The total amount of tritium released to Pen Branch was originally estimated to be approximately 7500 curies. This estimate was meant to be conservative and was based on tritium concentrations measured in Pen Branch during routine sampling operations. Tritium concentrations measured in the Savannah River at Highway 301 and near the intake to the Beaufort-Jasper canal provide new insight into the amount of tritium actually released from K-Reactor. Historical weekly averages of tritium concentrations in the Savannah River are plotted in Figure B12. Table B13 shows daily a verage tritium concentrations at Highway 301 bridge and Becks Ferry.

Estimates of the daily activity passing Highway 301 and Beaufort-Jasper were made from December 22, 1991 to January 15, 1992. Prior to December 25, concentrations were at normal levels for these locations. Nominal, five-year averages of tritium concentrations in the Savannah River at Highway 301 and Beaufort-Jasper (3.1 and 2.3 $\mathrm{pCi} / \mathrm{mL}$, respectively) were determined and used to remove other sources of tritium from the K-Reactor release estimate. Releases from SRS's Effluent Treatment Facility (ETF) caused tritium concentrations in the Savannah River to remain at levels slightly above normal in January. However, for conservatism, ETF tritium transported past the Highway 301 bridge between January 10 and 15 is included in the estimate of the total amount of tritium released from K-Reactor.Daily Savannah River flow rates were estimated from data collected at the Highway 301 bridge and at Highway 119 (river-mile 61.5) near Clyo, Georgia. River flow rates, and therefore transport estimates, may be subject to minor changes pending official publication by the USGS; differences are expected to be less than 3\%. River flow rates at Highway 119 were used to estimate tritium transport in the Savannah River past Becks Ferry.

Daily river flow rates and tritium transport at the Highway 301 bridge are shown in Table B14. It is estimated that the total tritium transported past monitoring stations at Highway 301 and Becks Ferry to be approximately 5670 and 5730 curies, respectively. ${ }^{6}$ Consideration was given to normal tritium levels when determining the amount of tritium transported down the Savannah River. Therefore, approximately 5700 curies of tritium were released to the Savannah River between December 22 and 25. 


\section{Health Impacts}

\section{Maximum Drinking-Water Dose}

Original estimates of dose to the maximum individual were calculated assuming a tritium concentration of $170 \mathrm{pCi} / \mathrm{mL}$ and a water intake of 2 liters per day for 3 days. These assumptions resulted in a predicted dose of $0.06 \mathrm{mrem}$. Maximum concentrations, however, in the Savannah River at Highway 301 were about three times less than original, conservative estimates.

The Effective Dose Equivalent (EDE) was estimated for a maximum individual who consumed 2 liters of river water each day that the tritium concentrations were elevated. ${ }^{6}$ It was assumed that the maximum individual consumed raw river water collected at the Highway 301 monitoring location. The dose to this person is higher than the actual doses received by users of the Beaufort-Japser and Port Wentworth water supplies; the Beaufort-Jasper plant closed its intake canals during plume passage and Port Wentworth concentrations are lower than those measured at Highway 301. The average tritium concentration at Highway 301 under normal conditions $(3.1 \mathrm{pCi} / \mathrm{mL})$ was subtracted from measured concentrations to determine the dose contribution from the K-Reactor release. A tritium dose factor of $6.3 \times 10-8 \mathrm{mrem} / \mathrm{pCi}$ was used to estimate the impacts. ${ }^{4}$

The radiation dose from tritium in the maximum individual's drinking water was approximately 0.035 mrem. ${ }^{6}$ The majority of this dose would have been delivered to this hypothetical maximum individual at Highway 301 between December 26 and January 1 . Tritium concentrations in the Savannah River at Hwy 301 returned to near normal levels on about January 10.

The maximum dose to individuals consuming treated water from the Beaufort-Jasper or Port Wentworth domestic water systems is 0.0096 and 0.030 mrem, respectively.' Dose estimates are based upon measured tritium concentrations in treated domestic water from the two facilities. Estimates are conservative since they are generated assuming a water consumption rate of 2 liters/day, each day the tritium concentrations were above normal. Additionally, workers at the Savannah Industrial Park (users of Port Wentworth water) were instructed not to drink the water during the time that tritium levels were elevated.

\section{Maximum Dose from the Consumption of Aquatic Species}

Estimates of the maximum dose to individuals who harvest fish and/or invertebrates from the Savannah River are presented below. Conservative dose estimates are much smaller via these pathways than through the drinking water pathway.

Concentrations of tritium in fish reach equilibrium with the river water in a few hours. For conservatism, it is assumed that the tritium concentration in fish is equivalent to the maximum daily average of concentrations measured at Highway $301(56.3 \mathrm{pCi} / \mathrm{mL})$. The dose to an individual who eats 20 fish (approximately 10\% of the annual average individual fish consumption, each fish being $50 \%$ edible and weighing 100 grams) with a tritium concentration of 56.3 $\mathrm{pCi} / \mathrm{mL}$ is approximately $0.0035 \mathrm{mrem}$. For the isolated case of an individual fishing in Steel Creek at the time of the peak tritium concentration, the dose could be as much as 20 times higher.

It is also assumed that invertebrates have been exposed to rivis water with a tritium concentration equal to the maximum measured concentration at Highway 301 and that tritium uptake is rapid in invertebrates. The dose to an individual who eats 1 quart of invertebrates (freshwater mussels) with a tritium concentration of $56.3 \mathrm{pCi} / \mathrm{mL}$ is 0.0035 mrem. The fish and mussel doses are equal since the net intake of tritiated water is 1 liter in both cases. The majority of shellfish (oysters) are harvested, however, in saltwater estuaries where the tritium concentration was about 1/10th the concentration in the Savannah River. Additionally, public concerns resulted in the harvesting of oysters being dramatically reduced during the passage of the tritium plume.

Oysters from the public beds at Fort Pulaski were sampled by both ETS and EMS. Concentrations of tritium in the sampled oysters ranged from about $2.1 \mathrm{pCi} / \mathrm{mL}$ to 8.3 $\mathrm{pCi} / \mathrm{mL}$.

An individual exposed through all pathways considered (water, fish, and invertebrate ingestion) would receive a maximum dose of about $0.042 \mathrm{mrem}$ resulting from the release at $\mathrm{K}-\mathrm{Reactor}$ 


\section{Average Individual and Population Dose}

Elevated tritium concentrations in the Savannah River at Becks Ferry and Abercom Creek resulted in higher than normal concentrations in the domestic water supplies at Beaufort-Jasper and Port Wentworth. The population dose to customer's of those water systems was calculated based on actual tritium concentration measurements of drinking water. ${ }^{7}$ Data presented here have been used to estimate the dose to the 50,000 consumers on the Beaufort-Jasper system and the 15,000 consumers on the Port Wentworth system, assuming that each user consumes one liter of water per day.

The dose to the average individuals at Beaufort-Jasper and Port Wentworth was 0.0048 and 0.015 mrem, respectively. The population dose to users of domestic water from the Beaufort-Jasper and Port Wentworth systems was approximately 0.24 and 0.23 person-rem, respectively. Details on the dose calculation and tritium concentrations in finished water can be obtained from.?

The population dose from consumption of fish and oysters harvested during the traversal of tritium in the Savannah River and its estuary is estimated to be 0.0019 person-rem for fish consumption and 0.0022 person-rem for oyster consumption. Total dose to the population drinking treated water and eating fish and oysters from the Savannah River is approximately 0.47 person-rem.

\section{EPA Drinking Water Standard}

The Environmental Protection Agency has established a standard which limits the radiation dose to any individual exposed via the drinking water pathway. The standard (40 CFR 141) reads as follows, "The average annual concentration of beta particle and photon activity from man-made radionuclides in drinking water shall not produce an annual dose equivalent to the total body or any internal organ greater than $4 \mathrm{mrem} / \mathrm{yr}$."

As demonstrated abnve, the dose to the maximum individual who drinks untreated river water at Highway 301 is less than 0.04 mrem, two orders of magnitude below the EPA standard. The concentrations measured at the water treatment plants were lower than those at Highway 301. Preliminary dose estimates for all of 1991 show that the maximum offsite individual receives a dose of about 0.14 mrem from tritium in the Savannah River (Figure B13). This dose includes all aqueous tritium releases from the SRS, including the K-Reactor incident.

\section{Dose to Aquatic Biota}

The Department of Energy, in DOE Order 5400.5, has established an interim dose limit for the protection of native aquatic organisms. The absorbed dose limit to these organisms is $1 \mathrm{rad} /$ day from exposure to radioactive substances in liquid effluents discharged to natural waterways.

Following the K-Reactor tritium release, the highest daily average tritium concentration in the Savannah River at Highway 301 was $56.3 \mathrm{pCi} / \mathrm{mL}$. Since tritium in fish equilibrates with tritium in water in a few hours, the dose to the fish can be calculated for a concentration of $56.3 \mathrm{pCi} / \mathrm{g}$ in fish. The maximum dose to a fish at Highway 301 was 0.016 $\mathrm{mrad} / \mathrm{day}$."

The highest dar'y average tritium concentration in Steel Creek mouth was approximately $1300 \mathrm{pCi} / \mathrm{mL}$ (1300 pCi/g in fish). The maximum dose to the fish in Steel Creek was $0.38 \mathrm{mrad} / \mathrm{day}^{3}$

\section{Special Topics}

Several one-time samples were collected for specific purposes. EMS gathered water samples from the $\mathrm{K}$-Area discharge for analysis to determine if any radionuclides other than tritium had been released; no other nuclides were detected. EMS also conducted a survey of the swamp from Pen Branch to Steel Creek on December 31 to determine whether any significant tritium inventory was being held in the swamp rather than being flushed through the swamp with the other water. This survey showed variable concentrations that mimicked the results of surveys at the mouth of Steel Creek, demonstrating that the swamp was not retaining substantial tritium from the release.

\section{Abercorn Creek/Port Wentworth Intake}

The pump station for the City of Savannah is located on Abercom Creek, a tributary of the Savannah River. Abercorn Creek is a small tidal freshwater creek, about five miles long, and its watershed is located within the Savannah River floodplain. The creek joins the Savannah River at river mile 29 , about one mile above $1-95$. Tides that range six teet are present in this freshwater region of the river. These tides result in a considerable amount of water being transported in and out of Abercorn Creek during a tidal cycle. As a result of the tidal movement and mixing of water in Abercorn Creek, pollutant release profiles are altered by 
the tidal exchange process in the creek and do not smoothly follow those that are in the river. At high tide, the tritium concentration at the pump station reflects the concentration that is actually in the river. At low tide, the tritium concentration represents the water that was stored in the upper reaches of Abercorn Creek.

The effect of the tides on the tritium concentration in Abercom Creek at the pump station (Figure B6) are obvious when compared to the tritium concentration measured ten miles upriver at Becks Ferry (Figure B5). In the early stage of the release, the tritium was higher during high tide (river water) and lower during low tide (water from the upper reach of the creek; the first part of the curve in Figure B6). After several tidal cycles, water in the upper reaches of Abercorn Creek had become mixed with the higner tritium concentrations in the river. As the tritium decreased in the Savannah River, the tritium concentration in the upper part of Abercorn Creek was higher than that of the river. When that occurred, the tritium concentration was lower at high tide (river water) and higher at low tide (latter part of the curve in Figure B6). After the river returned to a steady state tritium concentration and several tidal cycles, there was no difference between high and low water tritium concentrations (end of curve in Figure B6).

\section{The Savannah River Estuary}

On January 3, 1992, grab samples were collected in the Savannah River and in the estuary to the north and south of the river (Figure A3). The results are shown in Tables B11 and B12. Samples were collected along the Wilmington River from Wassaw Sound to the Savannah River (south sweep). A sweep of the Savannah River was then conducted from Mackey Point down to the river mouth. Finally sampling was performed in the vicinity of New River and Calibogue Sound (north sweep).

Results for the south sweep show that with increasing distance from the Savannah River tritium concentrations in the Wilmington River decreased. Concentrations of $\mathbf{1 3 . 5}$ $\mathrm{pCi} / \mathrm{mL}$ were measured near the Savannah River, decreasing to levels normally found in the Wassaw Sound. In the north sweep no elevated tritium concentrations were detected. Tritium concentrations in the Savannah River near Mackey Point reached $26.7 \mathrm{pCi} / \mathrm{mL}$. Samples collected downstream from Mackey Point showed decreasing tritium concentrations. Concentrations at Ft. Pulaski returned to normal levels by January 13 (Figure B9).

Longer-term studies were conducted at Thunderbolt Marina, Lazaretto Creek, Fort Pulaksi, Skidaway Institute and Priest Landing (Table B12 and Figure B10). Tritium concentrations were slightly elevated $(8-10 \mathrm{pCi} / \mathrm{mL})$ at the Thunderbolt Marina and in Lazaretto Creek during the first week in January but returned to normal levels by January 15 . Samples collected at Fort Pulaski showed a tidal influence (Figure B9). At low tide, when the water flow is dominated by the Savannah River, tritium cuncentrations were elevated. At high tide, when water flow is dominated by influx from the Atlantic Ocean, low tritium concentrations were measured. Samples collected near Skidaway Institute and Priest Landing typically had tritium concentrations of only a few pCi/mL (Table B12 and Figure B10). On January 10 a single sample collected at Priest Landing had a tritium concentration of $11.4 \mathrm{pCi} / \mathrm{mL}$. Since the tritium peak was of short duration, the most likely transport path was in the inland waterway between Savannah River estuary and Wassaw Sound."

\section{Acknowledgments}

The authors thank the SRS personnel who assisted in the sampling and analysis program. Numerous Senior Laboratory Technicians in ETS and EMS assisted in sample collection, sampler maintenance, courier trips, sample preparation, and counting. J.E. Miller organized and scheduled the work of the ETS Senior Laboratory Technicians. For TRAC's deployment, M. Hendrix provided maintenance support; J.D. Leyba and R.A. Sigg, both from the SRL Analytical Development Section, provided the Ultima Gold XR ${ }^{\mathrm{TM}}$ liquid scintillation cocktail.Individuals who are not associated with SRS are acknowledged for their assistance. Personnel from the Beaufort-Jasper and Port Wentworth water treatment plants collected many of the samples of raw and finished water. The TRAC staff thanks the personnel of the Beaufort-Jasper water treatment plant for their assistance during TRAC's deployment. 


\section{References}

1. Beals, D.M., Dunn, D.L., Hall, G., Kantelo, M.V., "Tritium Sample Analyses in the Savannah River and Associated Waterways Following the K-Reactor Release of December 1991", WSRC-TR-92-24, Westinghouse Savannah River Company, Aiken, SC, February 5, 1992.

2. Carlton, W.H., "Drinking Water Dose from K-Reactor Release", Westinghouse Savannah River Laboratory, SRL-ETS-910619, December 26, 1991.

3. Carlton, W.H., "Dose to Fish as a Result of the 12/91 K-Reactor Tritium Release", Westinghouse Savannah River Laboratory, SRL-ETS-920041, January 20, 1992.

4. US Department of Energy, "Internal Dose Conversion Factors for Calculation of Dose to the Public", DOE/EH-0071, July 1988.
5. Hamby, D.M., "LADTAP XL: An Innproved Electronic Spreadsheet Version of LADTAP II", Westinghouse Savannah River Company, WSRCRP-91-975, November 18, 1991.

6. Hamby, D.M., "Health Impact of Tritium Release from K-Reactor", Westinghouse Savannah River Company, Savannah River Laboratory, SRLETS-920001, January 28, 1992.

7. Hamby, D.M., "Individual and Population Dose to Users of the Savannah River Following K-Reactor Tritium Release", SRL-ETS-920061, January 29, 1992.

8. Hayes, D.W., "Tritium in the Savannah River Estuary and Adjacent Marine Waters", IAEA-SM-232/80, In Proceedings of the International Symposium on the Behaviour of Tritium in the Environment, San Francisco, October 1978. 
This page intentionally left blank 
Appendix A

Sampling Locations and Maps

M9202027i

11 
This page intentionally left blank 
Table A1. Water sampling locations from SRS to the Savannah River estuary.

Location

Comments

At SRS

Steel Creek

0.2 miles from its confluence with the Savannah River at river-mile 141.6

\section{On the Savannah River}

Highway 301 Bridge

Becks Ferry Boat Landing

In the Beaufort-Jasper Water Treatment Plant System

Canal Locations

200 yards from river

400 yards from river

At Black Creek

100 yards before lift station

Lift Station discharge

Highway 321

Dirt road

Highway 17

Jasper Road

Highway 278

End of canal at receiving pond

End of receiving pond

Intake to treatment plant

Raw water

Finished water
River-mile 118.7

River-mile 38.9

Canal begins at river-mile 39.2

0.4 miles from the Savannah River

0.6 miles from the river

2.9 miles from the river

5.8 miles from the river

7.3 miles from the river

12.8 miles from the river

14.7 miles from the river

17.7 miles from the river

\section{In the Port Wentworth Water Treatment Plant System}

Lift Station on Abercom Creek

2 miles from confluence of Abercorn Creek with the Savannah River at river-mile 29.0

Raw water

Finished water

\section{Savannah River Estuary}

Fort Pulaski

Priest Landing

Skidaway Institute

Lazaretto Creek

Thunderbolt Marina 
This page intentionally left blank

M9202027, 


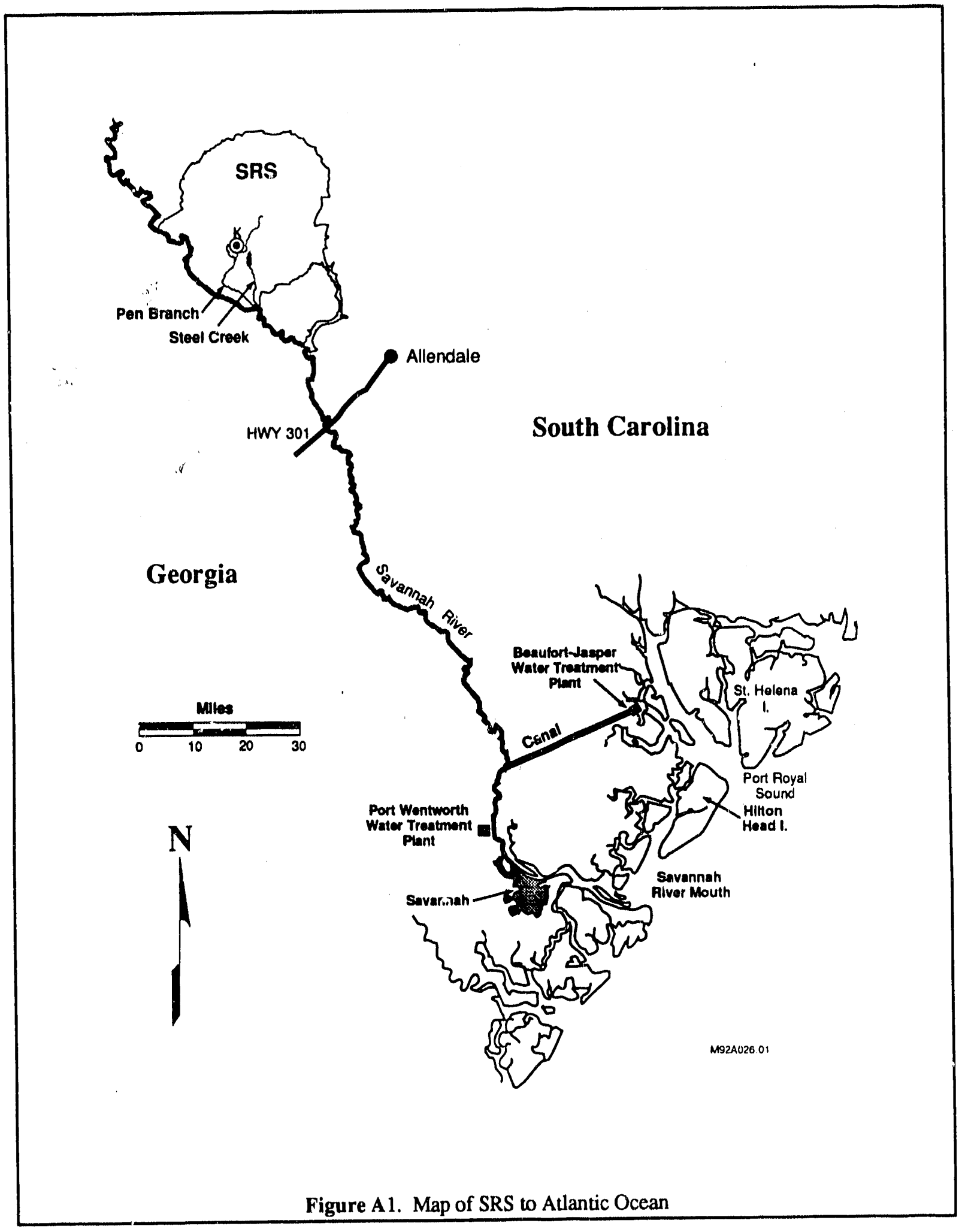




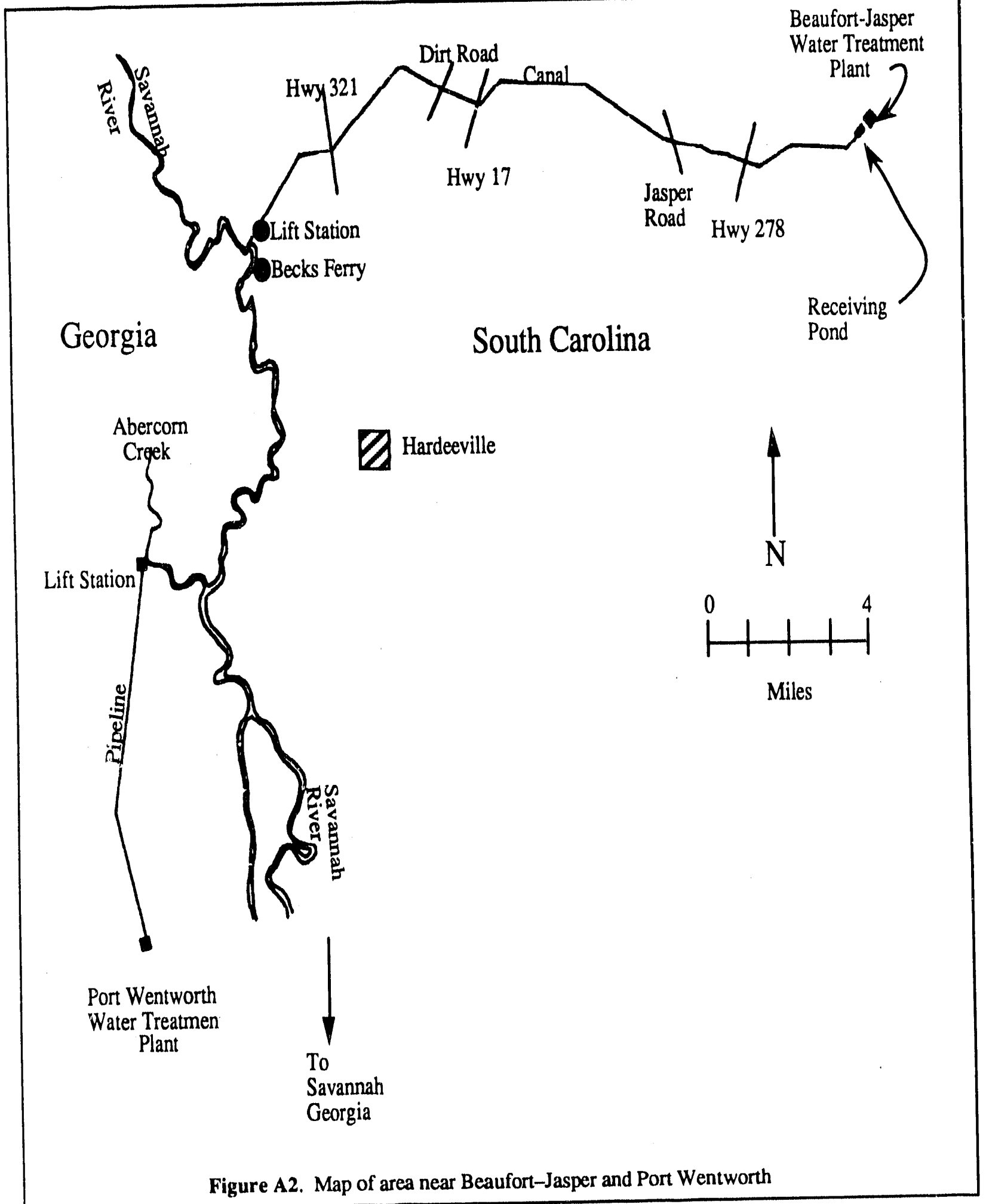




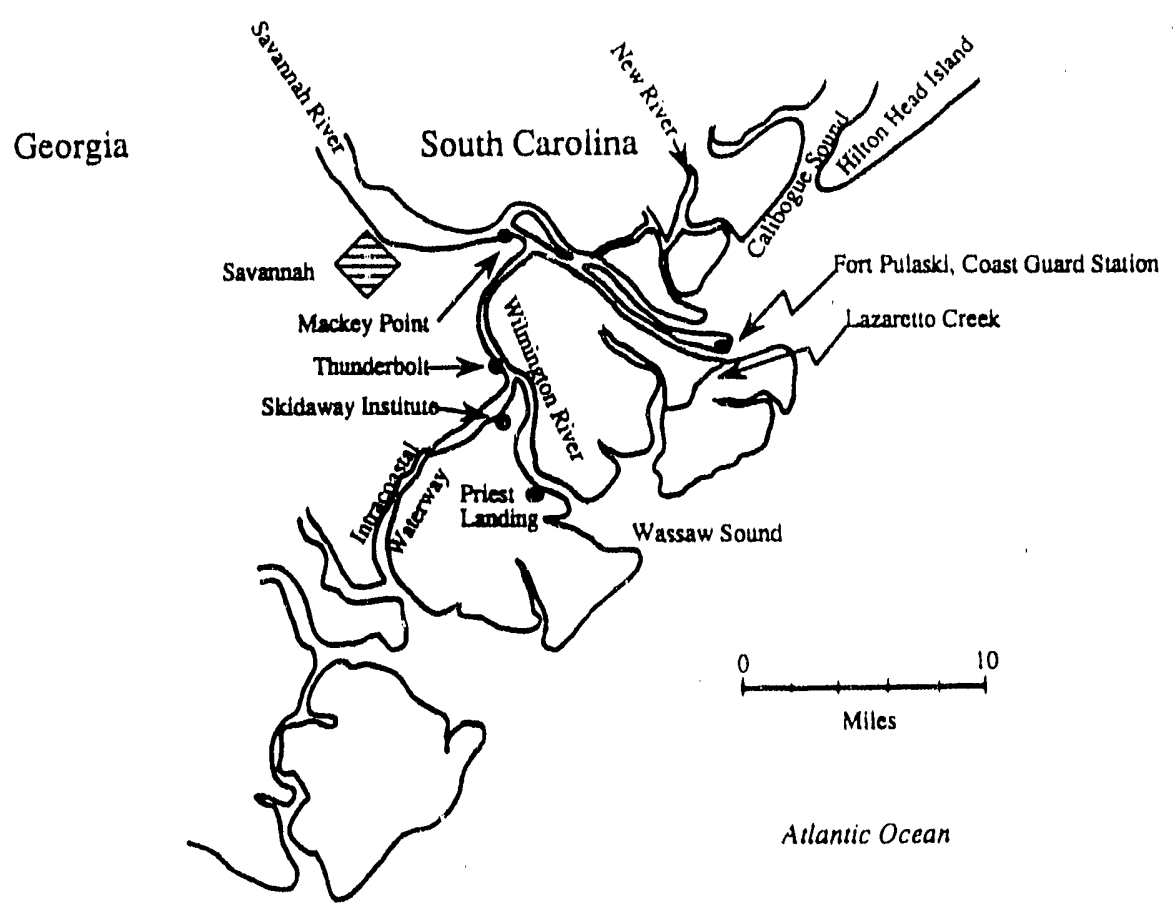

Figure A3. Map of the Savannah River estuary 
This page intentionally left blank 
Appendix B

Data Summary 
This page intentionally left blank 


\section{Anâlytical Methods}

\section{Laboratory Analyses}

Tritium activity in water samples was a determination using liquid scintillation counting (LSC). A Packard Tri-Carb $2050 \mathrm{~A}^{\mathrm{TM}}$ liquid scintillation counter with automatic quench correction was used for the analyses. At least one blank and one spike were prepared with each batch of samples received.

Samples received from the various sampling locations were assigned a sequential identification number and prepared for counting as soon after arrival as possible, usually within 12 hours of collection. Samples were prepared in batches depending on location. Three milliliters of sample were measured into a plastic liquid scintillation vial along with $19 \mathrm{~mL}$ of Packard Opti-Fluor ${ }^{T M}$ liquid scintillation cocktail. Each sample was prepared in duplicate. Blanks were prepared using $3.0 \mathrm{~mL}$ of distilled water and $19 \mathrm{~mL}$ of cocktail. Each spike contained $3.0 \mathrm{~mL}$ of distilled water, $19 \mathrm{~mL}$ of cocktail and $0.250 \mathrm{~mL}$ of a tritiated water standard traceable to the Nauional Institute of Standards and Technology (NIST). The spikes were used to confirm the automatic quench correction for counting efficiency.

Samples, blanks, and spikes were shaken to mix, transferred to the counting facility, placed into the counter, and allowed a 30 minute period for natural fluorescence to diminish before counting. A blank was counted prior to the samples. A single 10 minute count was performed on each sample, blank and spike, and, as time permitted, duplicate samples were counted. Due to time and instrument constraints, duplicates were counted from a few hours to several days after the original sample count. Not all sample duplicates were counted.

The reported concentration in a water sample was taken as either the average of the individual concentrations for duplicates or the individual concentration when duplicates were not analyzed. Individual concentrations were determined based on the volume of sample mixed with cocktail and the computer-assisted calculation of activity for the spectral tritium energy region for blank and gross samples. Net sample antivity was calculated by subtracting a running average blank activity. For convenience, concentrations tabulated in this appendix are shown to two decimal places, which in many cases is grcater accuracy than warrarited by the data. Typical measurement uncertainties, based on counting statistics at the $95 \%$ confidence level, are shown in Figure C1.

\section{Analyses Aboard the TRAC}

Tritium analyses were performed aboard the TRAĆ vehicle by LSC. Two different liquid scintillation cocktails were used. During the first week Opti-Fluor ${ }^{\mathrm{TM}}$ was used in the proportion of $19 \mathrm{~mL}$ cocktail and $3.0 \mathrm{~mL}$ sample; this is identical to the proportions used in the EETS laboratory.

Later, analyses were perf mixed with cocktail. Cor 1 sequently $10.0 \mathrm{~mL}$ of sample was mixed with $14 \mathrm{~mL}$ of Ultima Gold cocktail.

Samples were analyzed in duplicate using two Aston Model 1600 liquid scintillation counters. Reagent blanks were typically counted after every other sample. Reagent blanks were propared several times daily by mixing deionized water (a substitute for the sample) and cocklati in the appropriate proportions. Samples were typically counted in four sequential 5-minute counting intervals, for a total of 20 minutes; blanks were counted similarly.

LSC pulse height spectra for each counting interval were accumulated by a computer-based multichannel analyzer. Examination of the tritum energy region of individual spectra allowed the occasional outlier results to be excluded. After measurement, $0.100 \mathrm{~mL}$ of a NIST traceable tritiated water standard was added to each sample to determine the degree of quench. The standard conuained $1192 \mathrm{pCi}$ of tritium. The samples with added standard were then counted for 3 to 5 minutes.

The reported tritium concentration in a water sample was taken as the average of the individual concentrations for the duplicates. Individual concentrations were calculated based on the volume of sample mixed with cocktail, the known tritium content of the added standard, and the count rate in the tritium energy region of the spectra for the blank, the sample, and the 
sample with added standard. Typical measurement uncertainties, based on counting statistics at the $95 \%$ confidence level, are shown in Figure $\mathrm{C}$.

Measured tritium concentrations for all samples are reported in units of $\mathrm{pCl} / \mathrm{mL}$. When both the original sample and the duplicate were counted, the average result is reported with its precision ( $68 \%$ confidence level). If only the original sample was counted, the activity is reported without an associated uncertainty. TRAC analysis results are identified in all tables of Appendix $B$ by left justified collection times with results and uncertainties to one decimal place. For those samples analyzed by both the TRAC and the ETS laboratory, the results are shown separately in the tables and figures. 


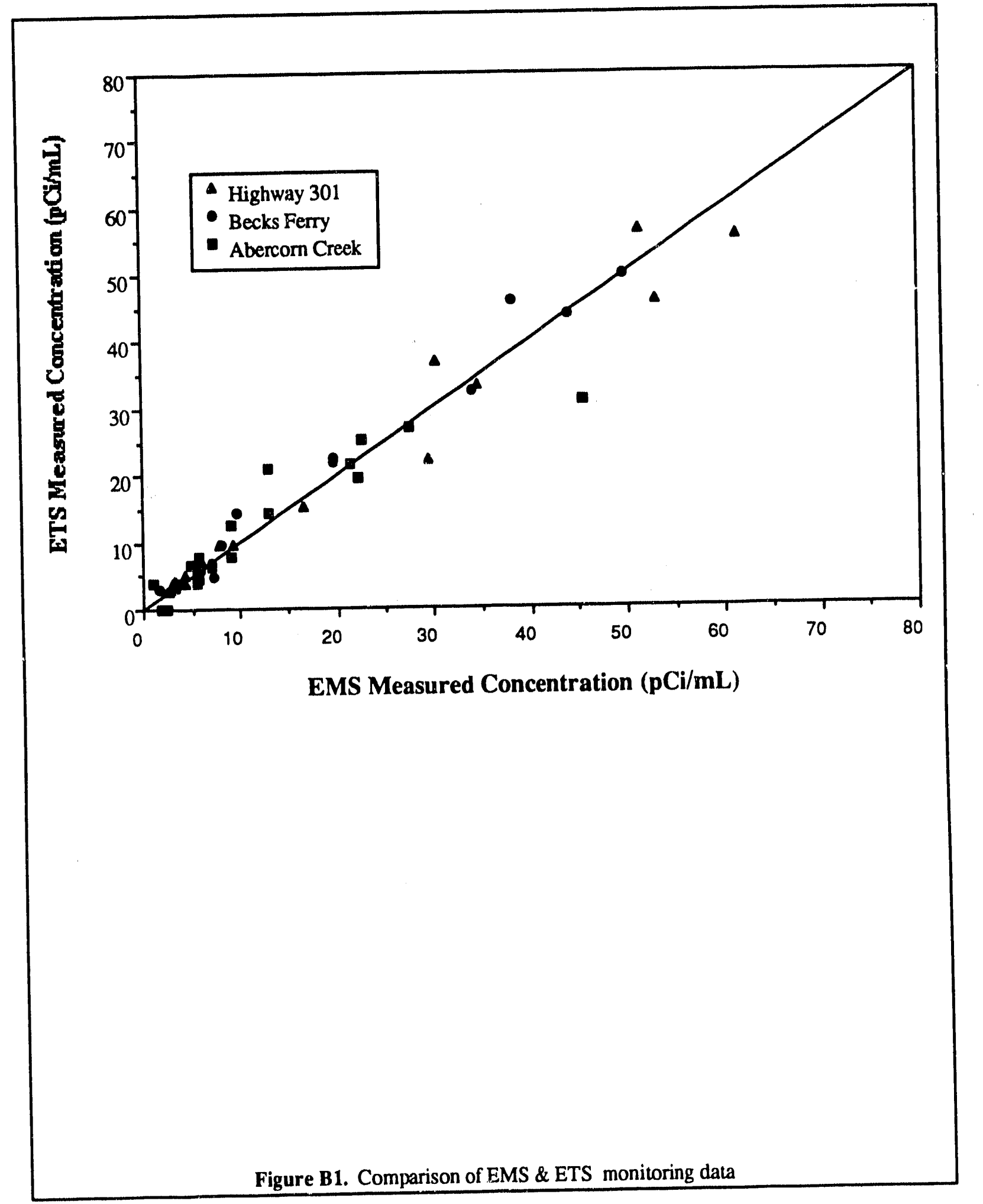




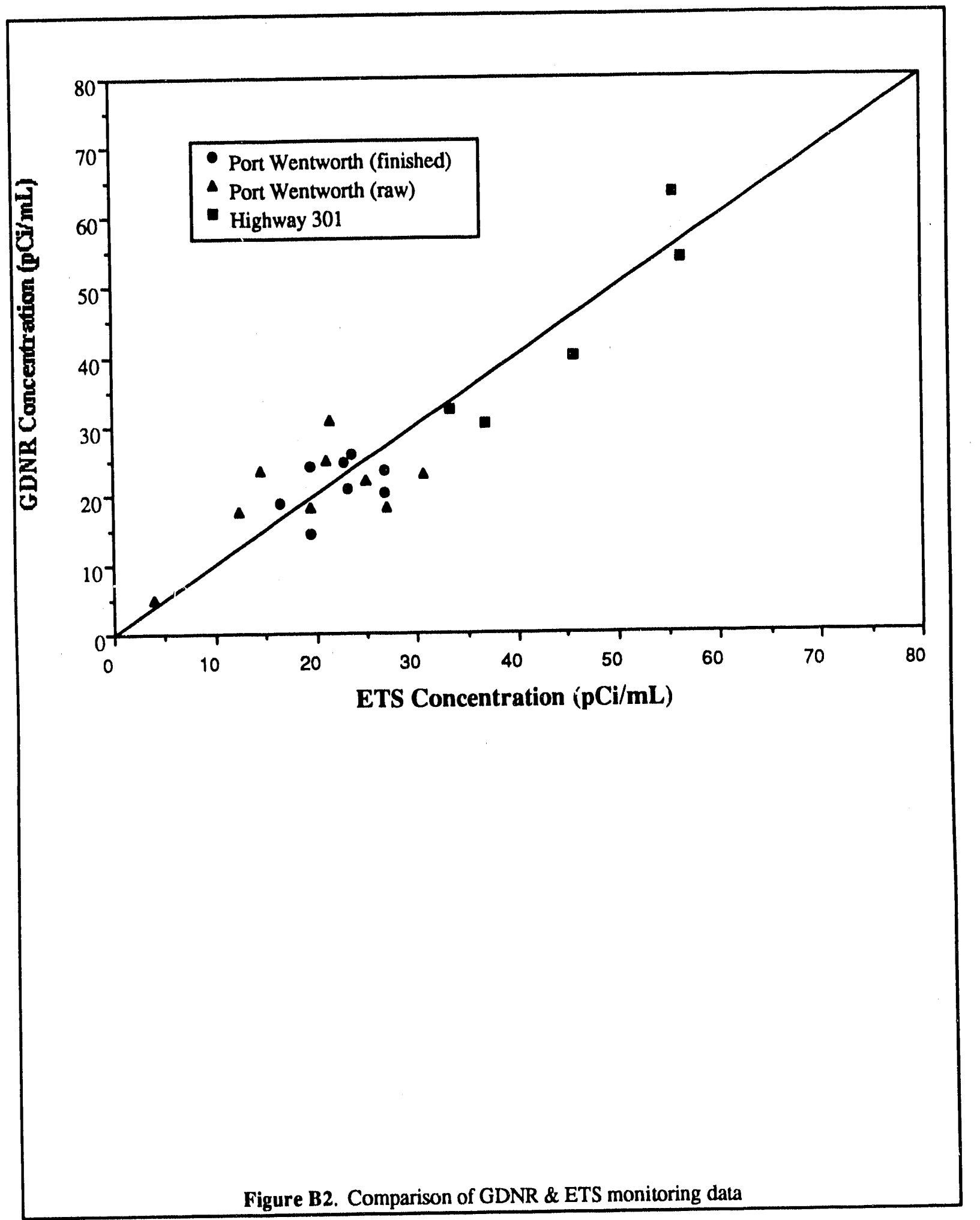




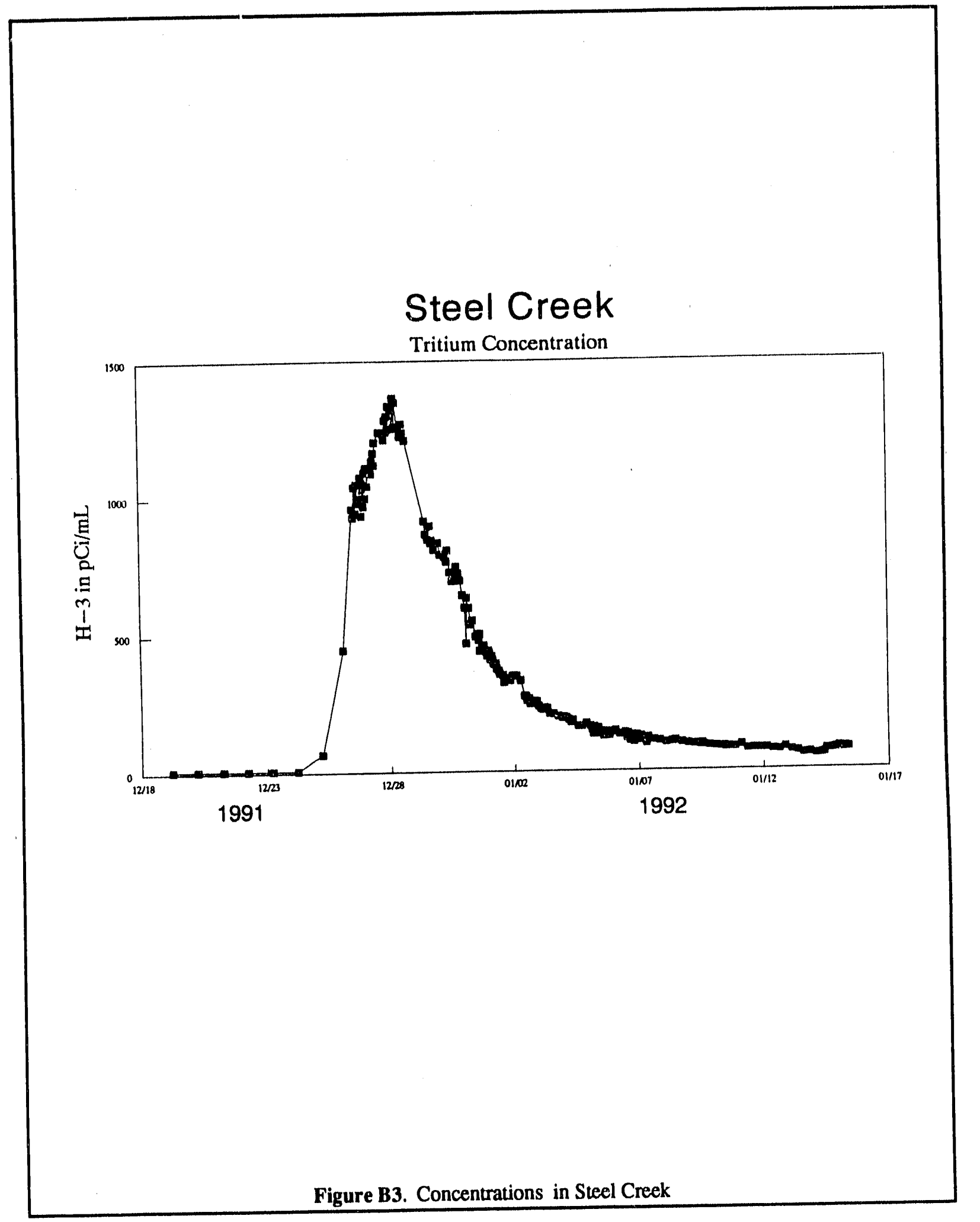


Highway 301

Tritium Concentration

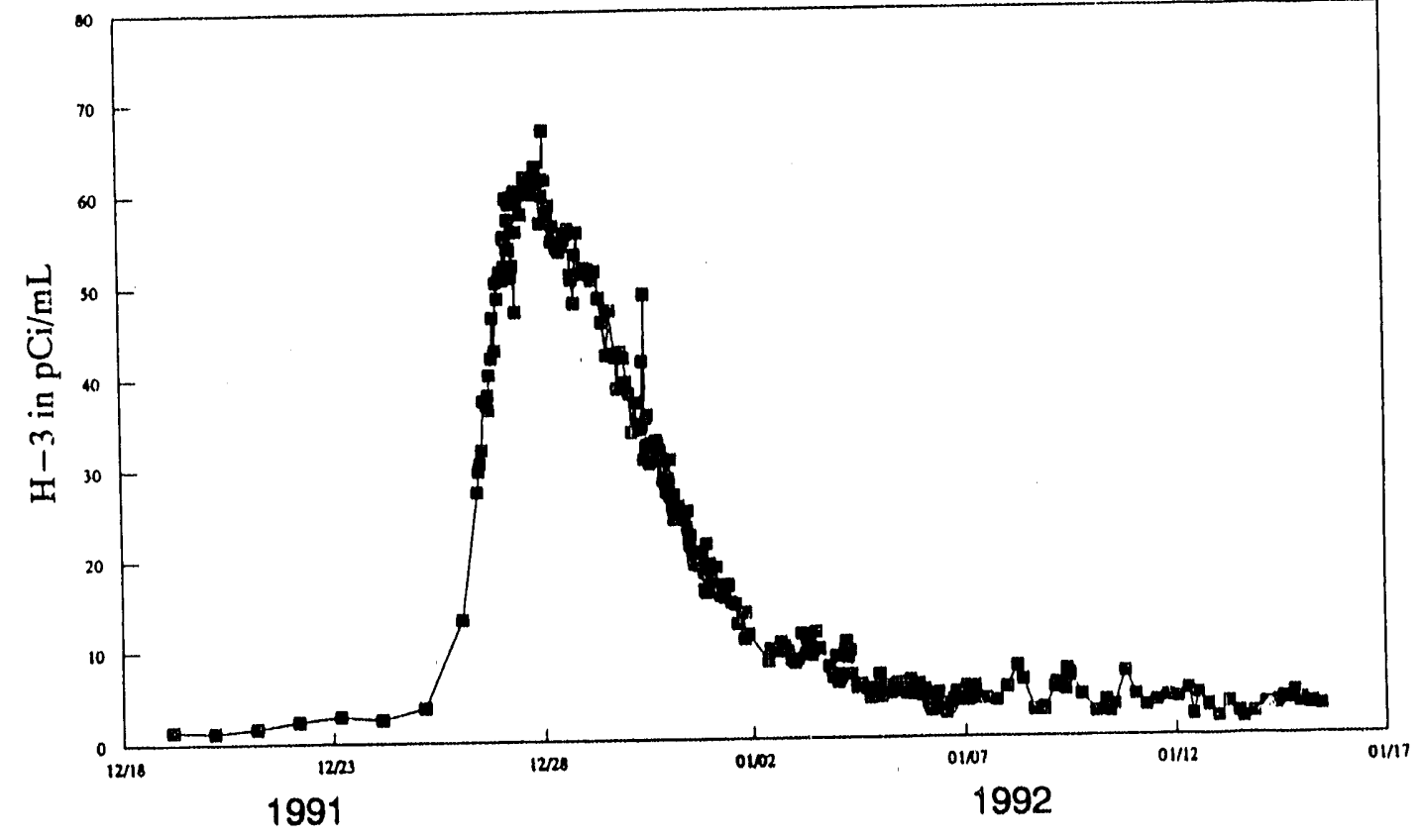

Figure B4. Concentrations at Highway 301 


\section{Savannah River At Becks Ferry}

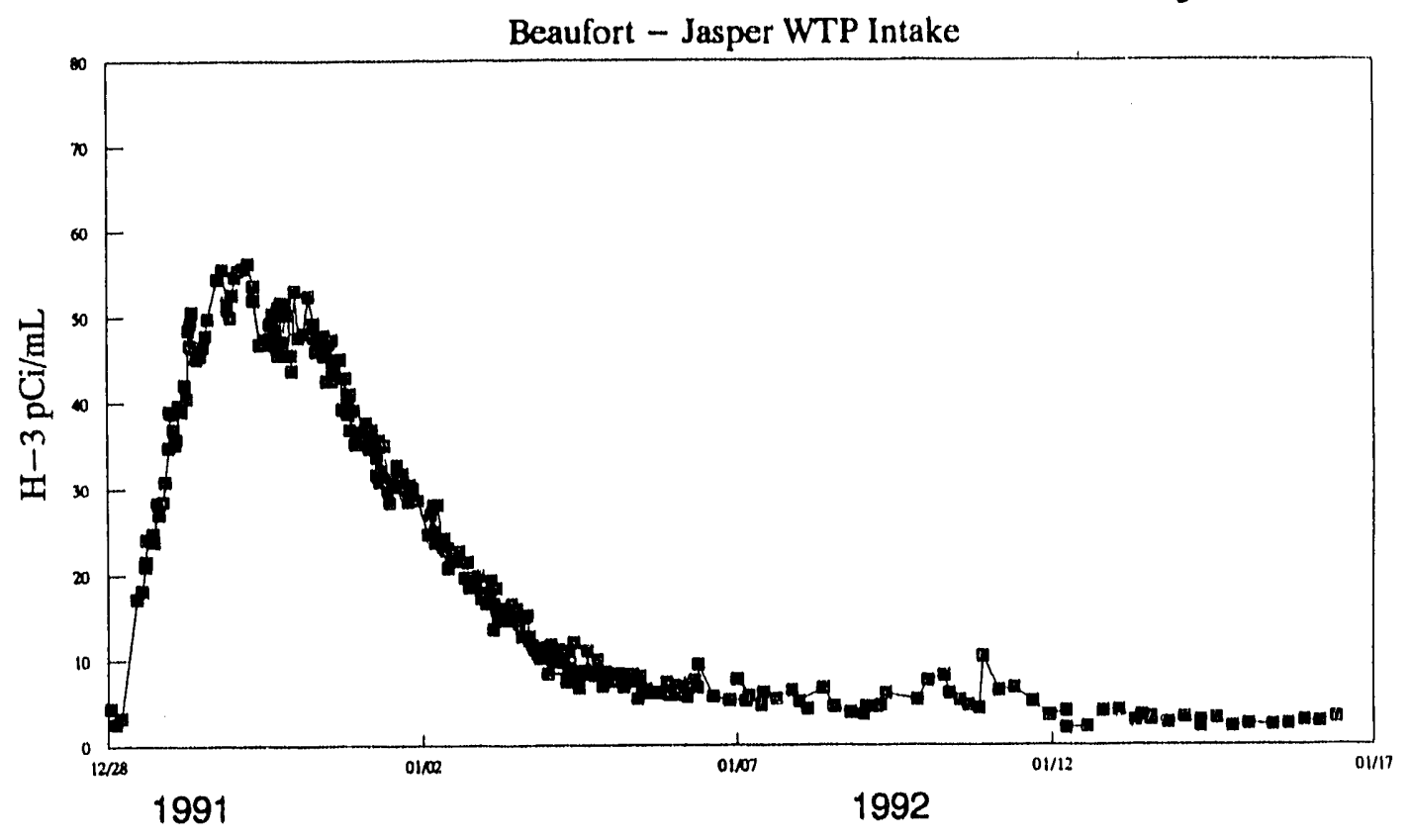

Figure B5. Concentrations at Becks Ferry 


\section{Savannah River At Abercorn Creek}

Port Wentworth WTP

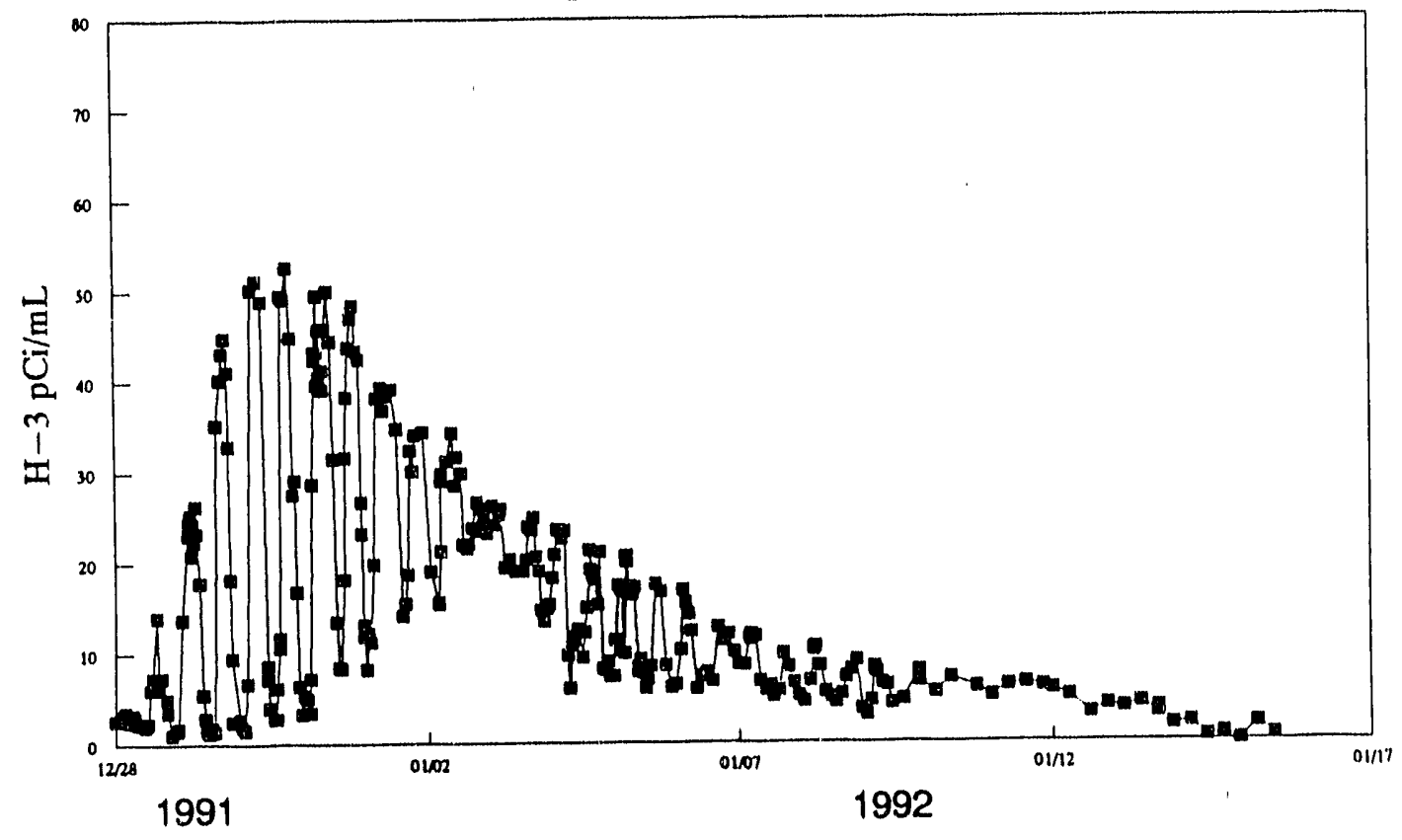

Figure B6. Concentrations at Abercorn Creek 


\section{Beaufort-Jasper Lift Station}

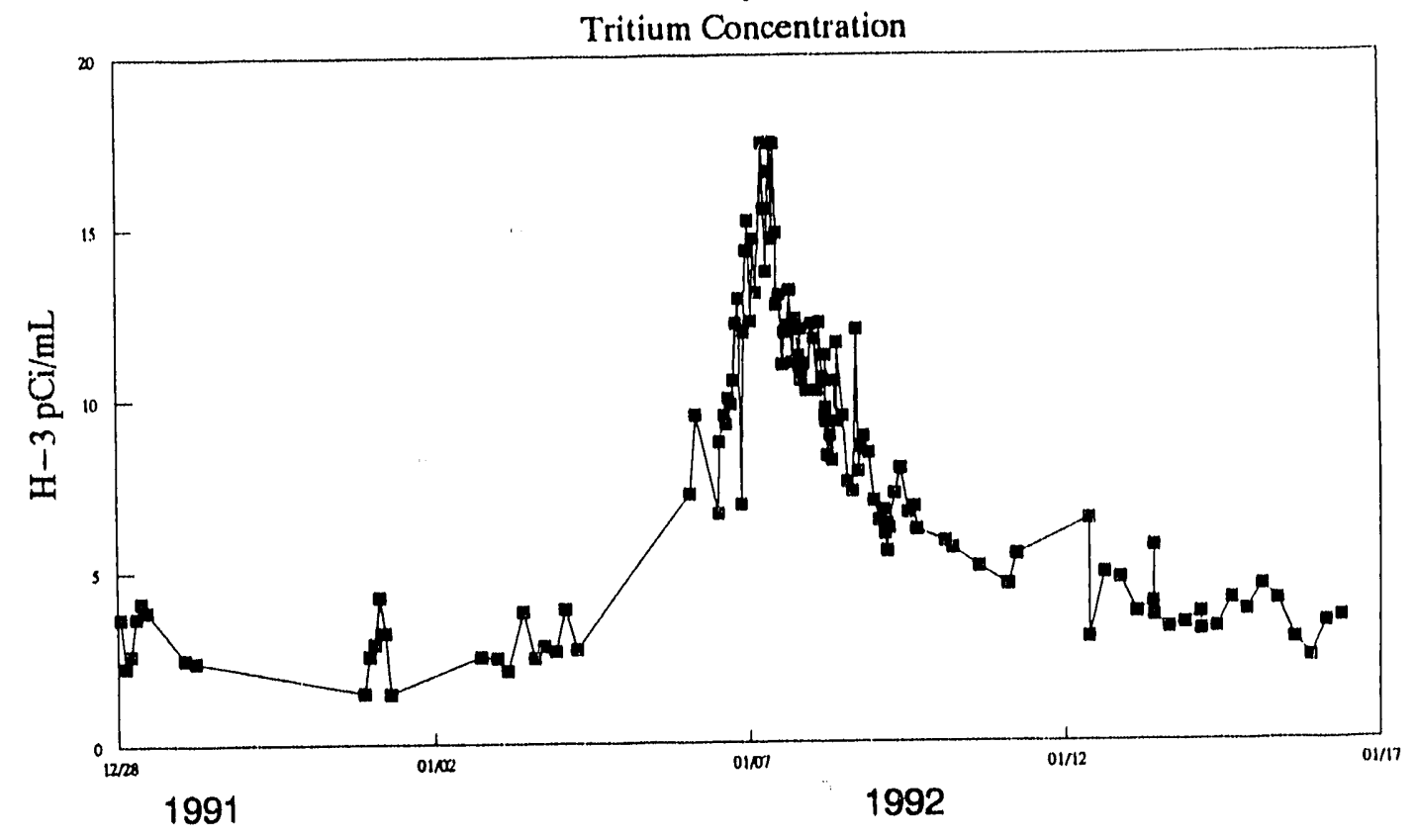

Figure B7. Concentrations at Beaufort-Jasper lift station 


\section{Beaufort-Jasper WTP Intake}

Tritium Concentration

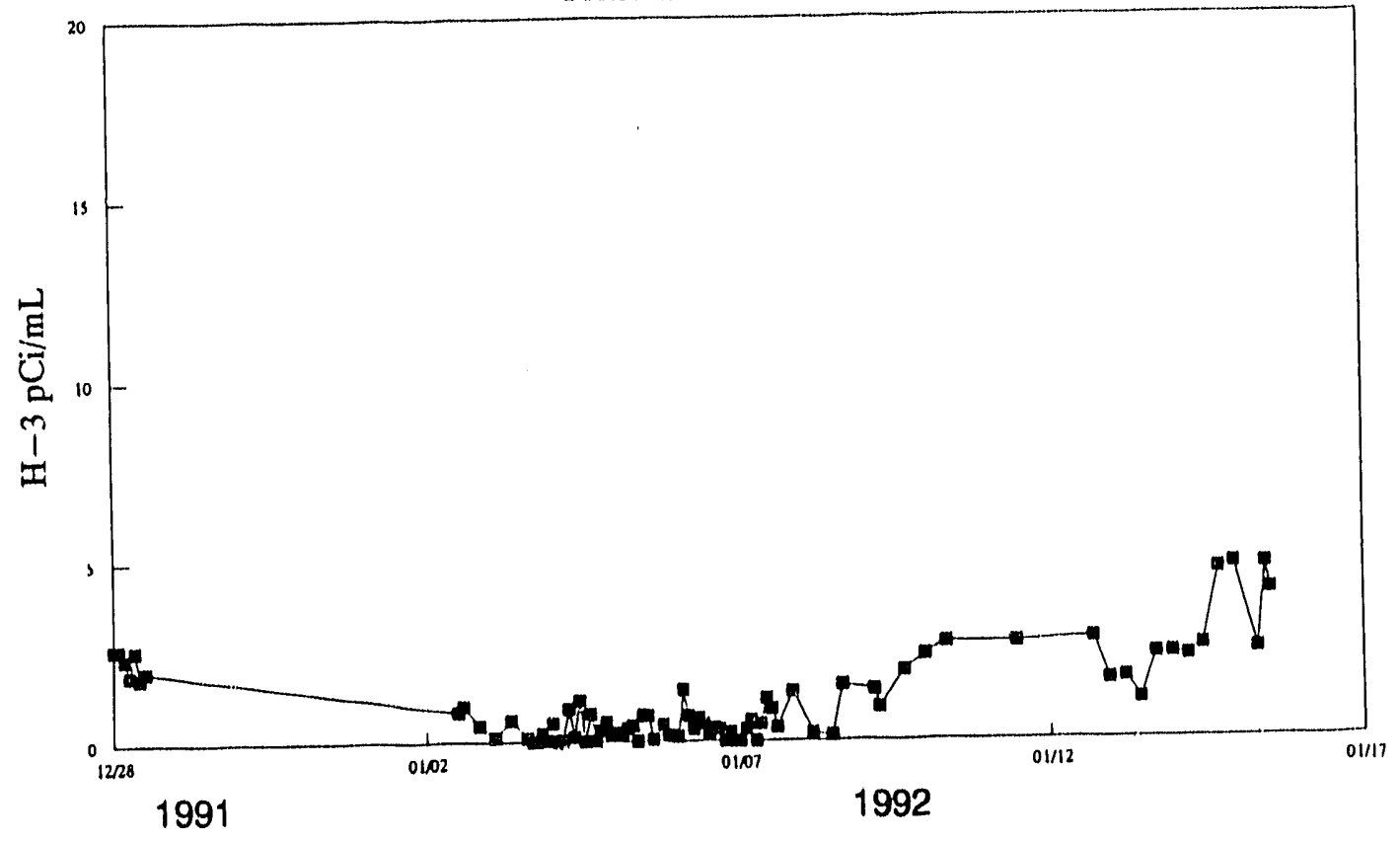

Figure B8. Concentrations at Beaufort-Jasper intake 


\section{Fort Pulaski}

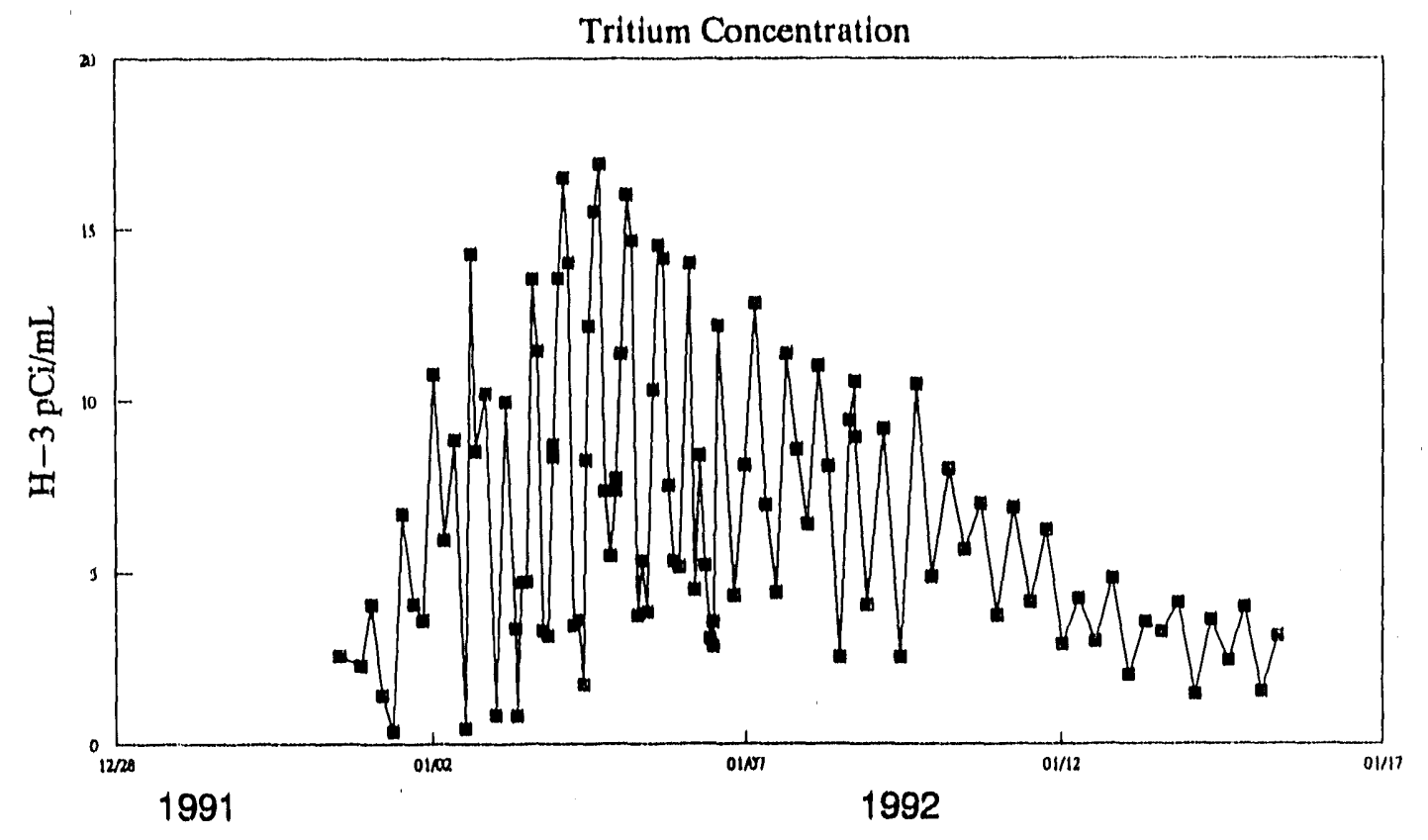

Figure B9. Concentrations near Fort Pulaski 


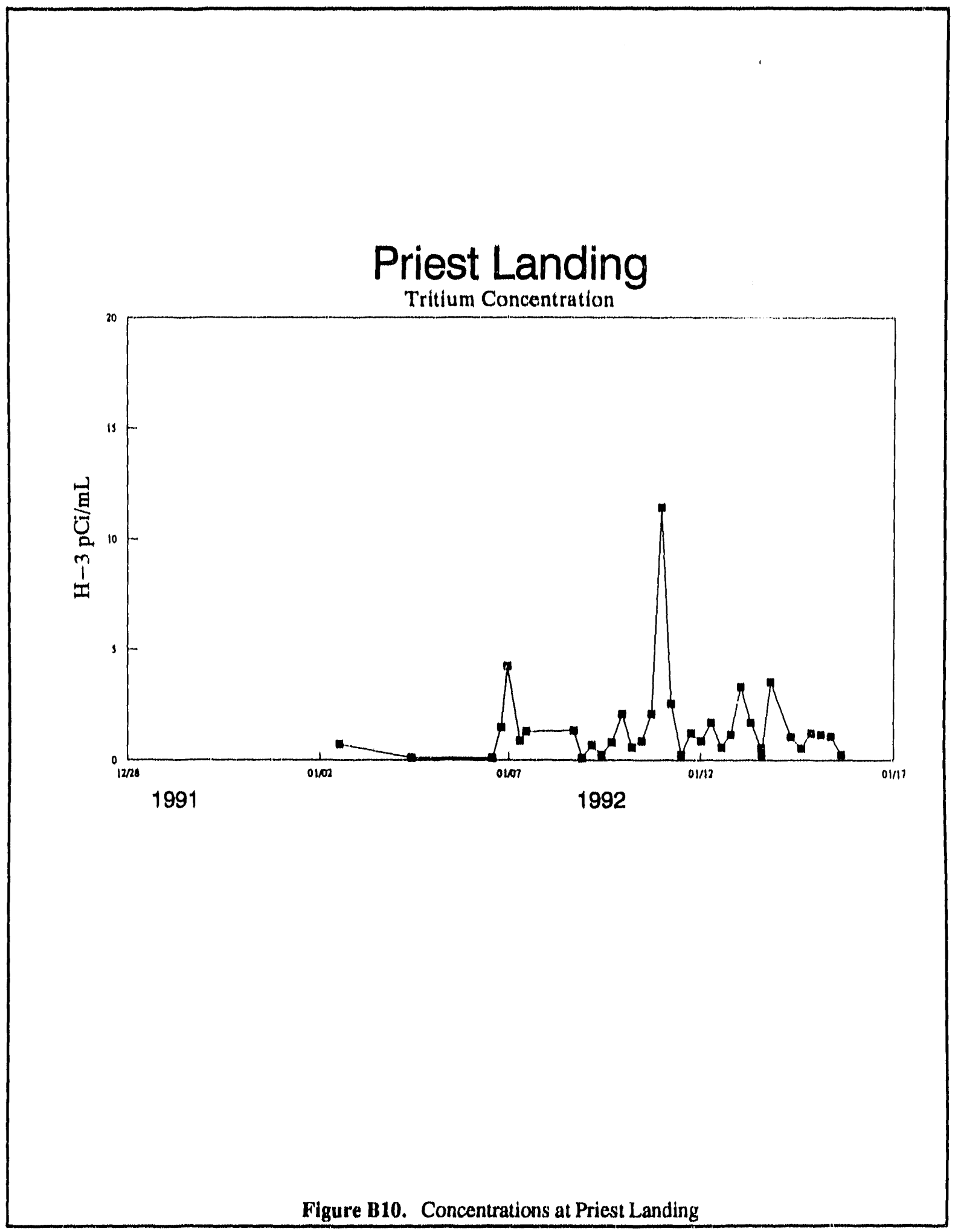




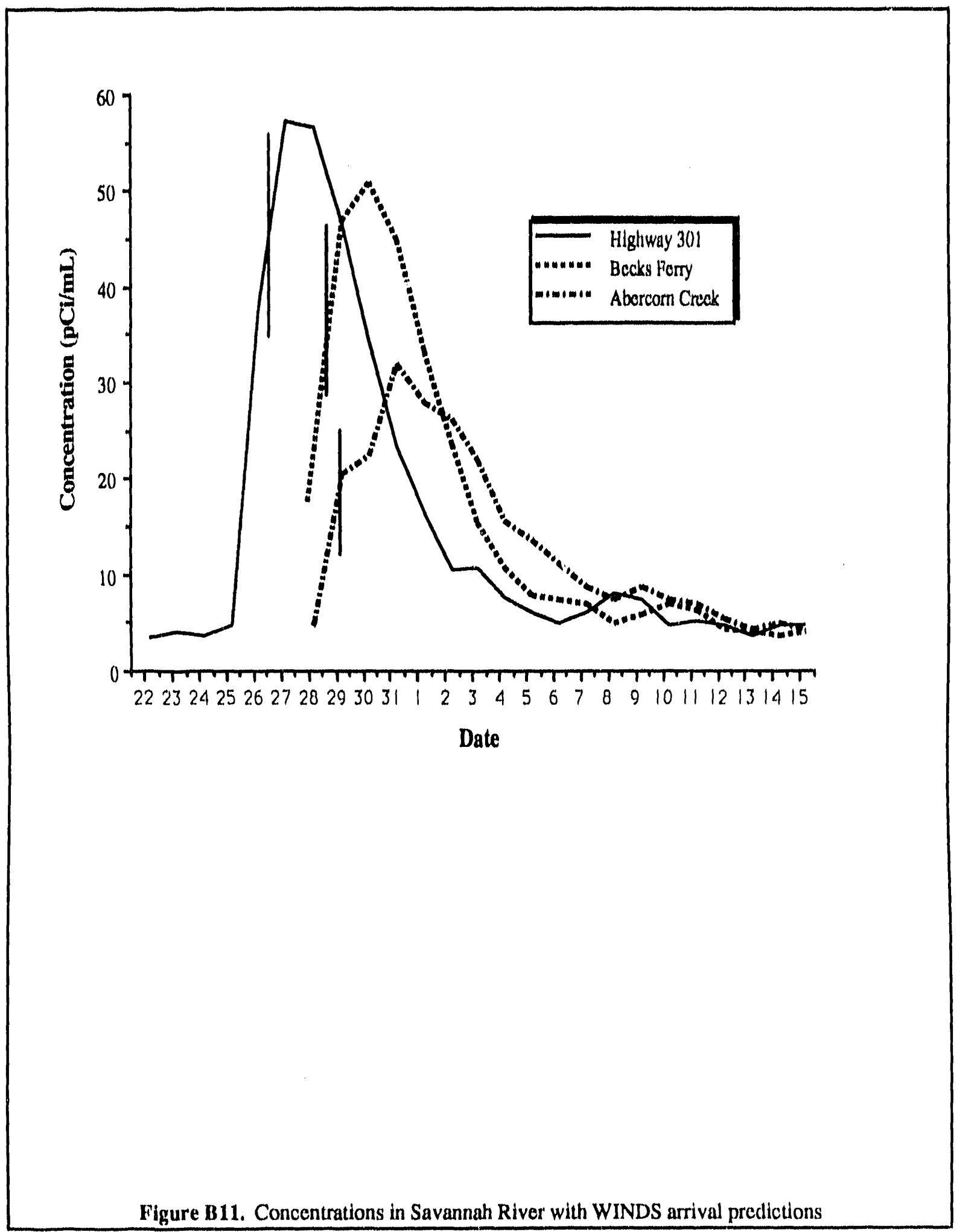




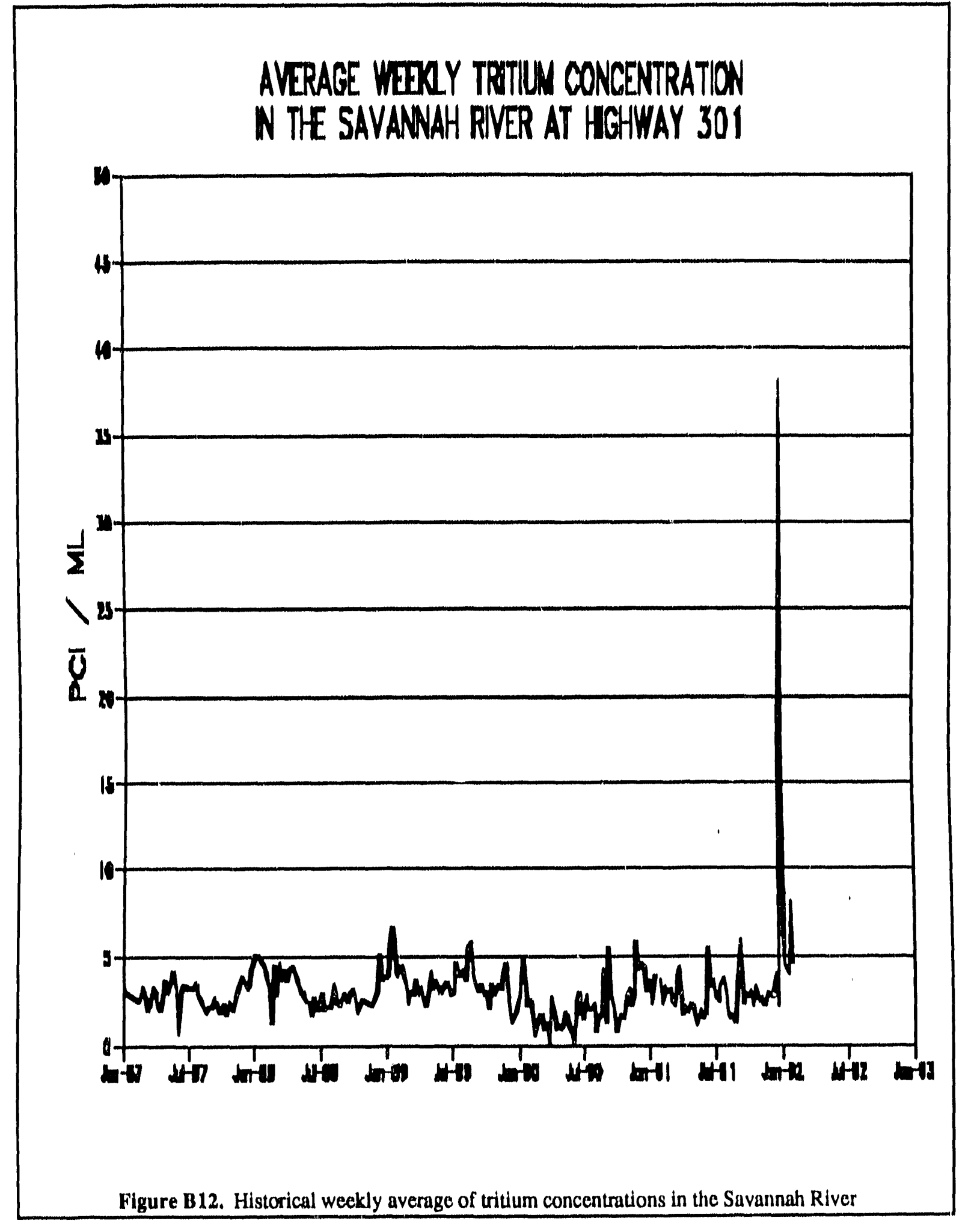




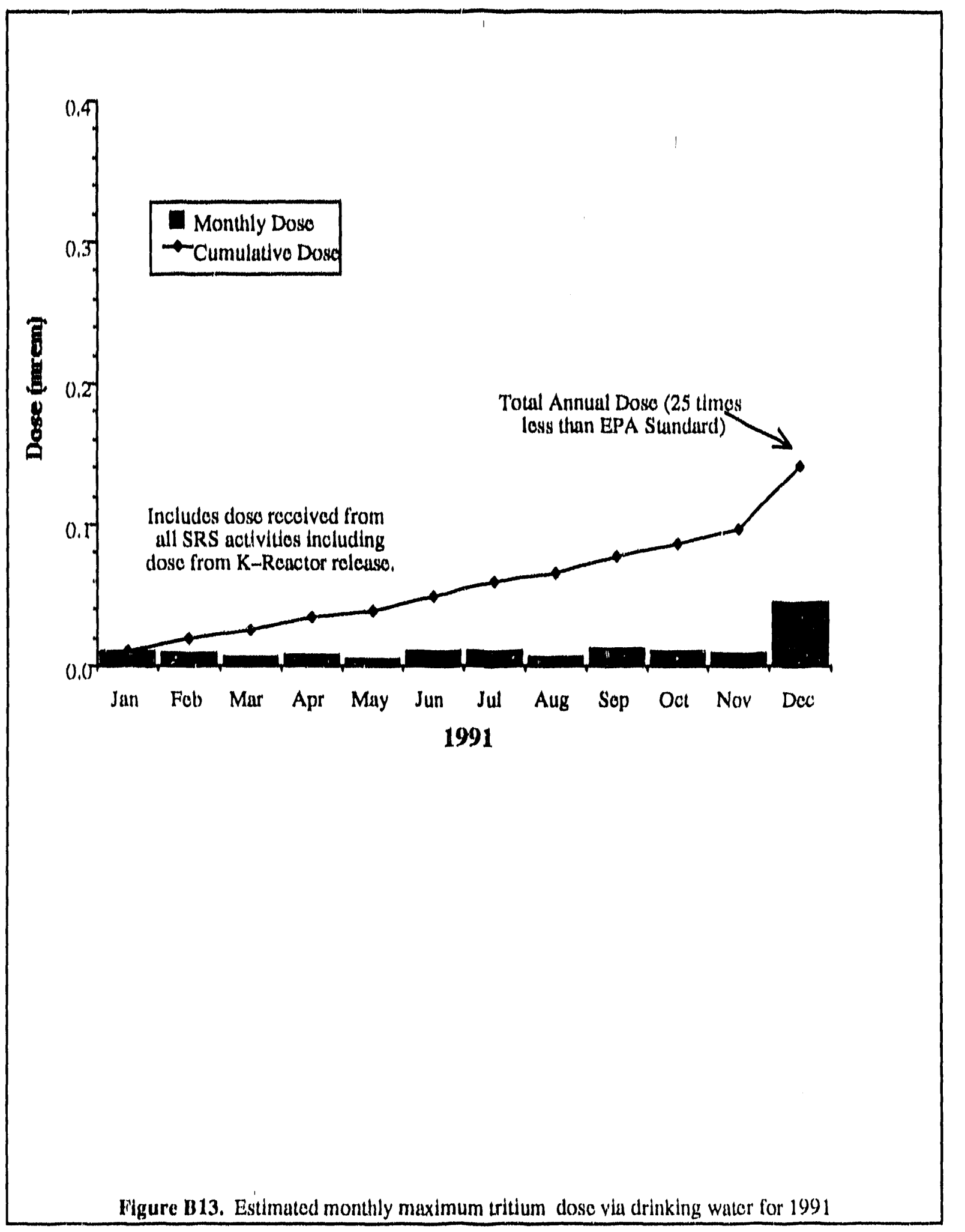


This page intentionally left blank 
Table B1. Steel Creek Survey

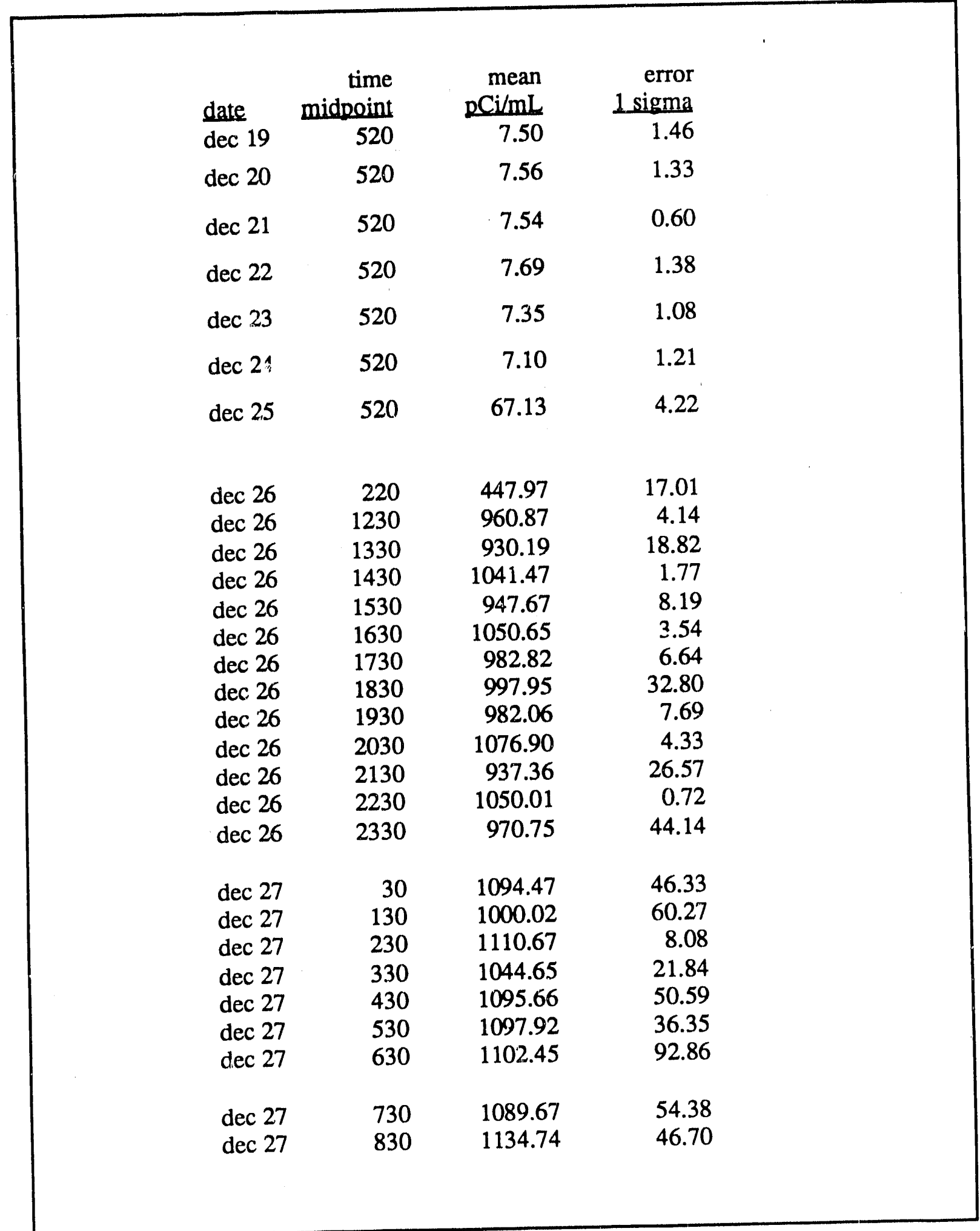


Table B1. Steel Creek Survey (Page 2 of 7)

\begin{tabular}{|c|c|c|c|}
\hline date & $\begin{array}{r}\text { time } \\
\text { midpoint }\end{array}$ & $\begin{array}{r}\text { mean } \\
\mathrm{pCi} / \mathrm{mL}\end{array}$ & $\begin{array}{r}\text { error } \\
1 \text { sigma } \\
\end{array}$ \\
\hline $\operatorname{dec} 27$ & 930 & 1163.83 & 8.96 \\
\hline $\operatorname{dec} 27$ & 1030 & $11^{-0.37}$ & 75.10 \\
\hline $\operatorname{dec} 27$ & 1100 & 1203.44 & 61.16 \\
\hline $\operatorname{dec} 27$ & 1500 & 1240.95 & 57.29 \\
\hline $\operatorname{dec} 27$ & 1900 & 1235.42 & 6.24 \\
\hline $\operatorname{dec} 27$ & 2000 & 1212.59 & \\
\hline $\begin{array}{l}\operatorname{dec} 27 \\
\operatorname{dec} 27\end{array}$ & $\begin{array}{l}2100 \\
2200\end{array}$ & $\begin{array}{l}1283.95 \\
1240.04\end{array}$ & 72.66 \\
\hline $\operatorname{dec} 27$ & 2300 & 1299.03 & 80.81 \\
\hline $\operatorname{dec} 28$ & 0 & 1250.17 & \\
\hline $\operatorname{dec} 28$ & 100 & 1335.55 & 133.81 \\
\hline $\operatorname{dec} 28$ & 300 & 1326.52 & 81.59 \\
\hline $\operatorname{dec} 28$ & 400 & 1253.73 & \\
\hline $\operatorname{dec} 28$ & 500 & 1364.47 & 9.36 \\
\hline $\operatorname{dec} 28$ & 600 & 1259.27 & \\
\hline $\operatorname{dec} 28$ & 700 & 1348.49 & 18.43 \\
\hline $\operatorname{dec} 28$ & 900 & 1255.30 & \\
\hline $\operatorname{dec} 28$ & 1100 & 1224.32 & 69.28 \\
\hline $\operatorname{dec} 28$ & 1300 & 1268.66 & \\
\hline $\operatorname{dec} 28$ & 1400 & 1237.44 & 19.57 \\
\hline $\operatorname{dec} 28$ & 1600 & 1209.87 & 54.23 \\
\hline $\operatorname{dec} 29$ & 1000 & 916.33 & 45.39 \\
\hline $\operatorname{dec} 29$ & 1130 & 867.20 & \\
\hline $\operatorname{dec} 29$ & 1330 & 847.17 & \\
\hline $\operatorname{dec} 29$ & 1530 & 898.53 & \\
\hline $\operatorname{dec} 29$ & 1630 & 834.06 & \\
\hline $\operatorname{dec} 29$ & 1730 & 845.13 & 37.05 \\
\hline $\operatorname{dec} 29$ & 1930 & 810.93 & 1.82 \\
\hline $\operatorname{dec} 29$ & 2130 & 834.04 & 54.06 \\
\hline $\operatorname{dec} 29$ & 2330 & 835.63 & 42.72 \\
\hline
\end{tabular}


Table B1. Steel Creek Survey (Page 3 of 7)

\begin{tabular}{|c|c|c|c|}
\hline date & $\begin{array}{r}\text { time } \\
\text { midpoint }\end{array}$ & $\begin{array}{c}\text { mean } \\
\mathrm{pCi} / \mathrm{mL}\end{array}$ & $\begin{array}{r}\text { error } \\
1 \text { sigma } \\
\end{array}$ \\
\hline $\operatorname{dec} 30$ & 130 & 792.05 & 10.70 \\
\hline $\operatorname{dec} 30$ & 330 & 792.73 & 3.85 \\
\hline $\operatorname{dec} 30$ & 530 & 783.84 & 12.22 \\
\hline $\operatorname{dec} 30$ & 730 & 766.23 & 2.92 \\
\hline $\operatorname{dec} 30$ & 830 & 807.87 & \\
\hline $\operatorname{dec} 30$ & 1030 & 727.54 & \\
\hline $\operatorname{dec} 30$ & 1230 & 695.08 & \\
\hline $\operatorname{dec} 30$ & 1430 & 709.94 & \\
\hline $\operatorname{dec} 30$ & 1530 & 728.11 & 29.20 \\
\hline $\operatorname{dec} 30$ & 1630 & 747.73 & \\
\hline $\operatorname{dec} 30$ & 1830 & 722.67 & \\
\hline $\operatorname{dec} 30$ & 2030 & 696.86 & \\
\hline $\operatorname{dec} 30$ & 2230 & 643.13 & 26.69 \\
\hline $\operatorname{dec} 31$ & 30 & 598.69 & \\
\hline $\operatorname{dec} 31$ & 200 & 468.92 & 10.66 \\
\hline $\operatorname{dec} 31$ & 230 & 633.08 & \\
\hline $\operatorname{dec} 31$ & 430 & 595.65 & \\
\hline $\operatorname{dec} 31$ & 430 & 536.13 & \\
\hline $\operatorname{dec} 31$ & 1100 & 492.72 & 4.04 \\
\hline $\operatorname{dec} 31$ & 1500 & 500.66 & 34.27 \\
\hline $\operatorname{dec} 31$ & 1600 & 480.49 & \\
\hline $\operatorname{dec} 31$ & 1700 & 460.01 & \\
\hline $\operatorname{dec} 31$ & 1800 & 460.48 & \\
\hline $\operatorname{dec} 31$ & 1900 & 459.05 & \\
\hline $\operatorname{dec} 31$ & 2000 & 444.00 & 16.08 \\
\hline $\operatorname{dec} 31$ & 2100 & 435.95 & 20.87 \\
\hline $\operatorname{dec} 31$ & 2200 & 422.20 & \\
\hline $\operatorname{dec} 31$ & 2300 & 440.51 & 4.62 \\
\hline jan 1 & 0 & 433.36 & \\
\hline jan 1 & 100 & 410.56 & 24.42 \\
\hline jan 1 & 200 & 420.97 & 9.06 \\
\hline jan 1 & 300 & 407.57 & 0.02 \\
\hline jan 1 & 400 & 395.19 & 21.98 \\
\hline jan 1 & 500 & 392.53 & 19.75 \\
\hline
\end{tabular}


Table B1. Steel Creek Survey (Page 4 of 7)

\begin{tabular}{|c|c|c|c|}
\hline date & $\begin{array}{r}\text { time } \\
\text { midpoint }\end{array}$ & $\begin{array}{l}\text { mean } \\
\mathrm{pCi} / \mathrm{mL}\end{array}$ & $\begin{array}{r}\text { error } \\
1 \text { sigma }\end{array}$ \\
\hline jan 1 & 600 & 392.96 & 3.20 \\
\hline jan 1 & 700 & 376,23 & 18.36 \\
\hline jan 1 & 900 & 368.00 & 15.59 \\
\hline jan 1 & 1000 & 356.57 & 22.9 \\
\hline jan 1 & 1300 & 351.78 & \\
\hline jan 1 & 1400 & 326.39 & \\
\hline jan 1 & 1800 & 339.30 & \\
\hline jan 1 & 2000 & 331.81 & \\
\hline jan 1 & 2200 & 348.05 & \\
\hline jan 2 & 0 & 350.47 & \\
\hline jan 2 & 200 & 347.68 & \\
\hline jan 2 & 600 & 332.31 & 5.85 \\
\hline jan 2 & 1000 & 275.03 & \\
\hline jan 2 & 1100 & 273.48 & \\
\hline jan 2 & 1200 & 259.99 & \\
\hline $\operatorname{jan} 2$ & 1400 & 265.70 & 10.23 \\
\hline $\operatorname{jan} 2$ & 1500 & 246.00 & \\
\hline jan 2 & 1700 & 246.15 & 0.55 \\
\hline jan 2 & 1900 & 255.61 & \\
\hline jan 2 & 2000 & 250.58 & 3.06 \\
\hline jan 2 & 2100 & 253.66 & \\
\hline jan 2 & 2300 & 237.32 & 4.67 \\
\hline jan 3 & 100 & 229.04 & \\
\hline jan 3 & 300 & 226.02 & \\
\hline jan 3 & 500 & 231.03 & \\
\hline jan 3 & 700 & 227.55 & 4.40 \\
\hline jan 3 & 930 & 209.67 & 7.60 \\
\hline jan 3 & 1330 & 209.43 & 7.79 \\
\hline jan 3 & 1730 & 200.85 & 8.94 \\
\hline jan 3 & 2130 & 193.89 & 12.68 \\
\hline jan 3 & 2330 & 197.00 & \\
\hline
\end{tabular}


Table B1. Steel Creek Survey (Page 5 of 7)

\begin{tabular}{|c|c|c|c|}
\hline date & $\begin{array}{l}\text { time } \\
\text { midpoint }\end{array}$ & $\begin{array}{c}\text { mean } \\
\mathrm{pCi} / \mathrm{mL}\end{array}$ & $\begin{array}{r}\text { error } \\
1 \text { sigma }\end{array}$ \\
\hline jan 4 & 130 & 193.52 & 1.48 \\
\hline jan 4 & 330 & 187.79 & \\
\hline jan 4 & 530 & 177.49 & \\
\hline jan 4 & 730 & 183.80 & 10.03 \\
\hline jan 4 & 1230 & 163.02 & \\
\hline jan 4 & 1630 & 163.00 & \\
\hline jan 4 & 2030 & 173.53 & \\
\hline jan 5 & 30 & 162.62 & 2.40 \\
\hline jan 5 & 230 & 148.37 & 6.70 \\
\hline jan 5 & 330 & 133.74 & \\
\hline jan 5 & 430 & 160.63 & \\
\hline jan 5 & 730 & 134.16 & 3.98 \\
\hline jan 5 & 830 & 155.88 & \\
\hline jan 5 & 1030 & 144.56 & \\
\hline jan 5 & 1330 & 125.44 & 17.14 \\
\hline jan 5 & 1630 & 142.97 & \\
\hline jan 5 & 1830 & 128.16 & \\
\hline jan 5 & 1930 & 137.44 & 11.27 \\
\hline jan 5 & 2230 & 141.16 & 1.82 \\
\hline jan 6 & 30 & 144.79 & \\
\hline jan 6 & 430 & 132.51 & 3.18 \\
\hline jan 6 & 830 & 134.12 & \\
\hline jan 6 & 1000 & 138.25 & \\
\hline jan 6 & 1100 & 132.03 & 20.06 \\
\hline jan 6 & 1200 & 119.64 & 14.31 \\
\hline jan 6 & 1300 & 136.44 & 7.94 \\
\hline jan 6 & 1400 & 127.50 & 9.57 \\
\hline jan 6 & 1500 & 109.82 & 5.18 \\
\hline jan 6 & 1600 & 120.25 & \\
\hline jan 6 & 1700 & 130.57 & 13.72 \\
\hline jan 6 & 1800 & 122.71 & \\
\hline an 6 & 1900 & 104.25 & \\
\hline jan 6 & 2000 & 124.37 & 25.69 \\
\hline jan 6 & 2100 & 125.15 & \\
\hline jan 6 & 2200 & 129.95 & 17.25 \\
\hline jan 6 & 2300 & 121.54 & 4.85 \\
\hline
\end{tabular}


Table B1. Steel Creek. Survey (Page 6 of 7)

\begin{tabular}{|c|c|c|c|}
\hline date & $\begin{array}{r}\text { time } \\
\text { midpoint }\end{array}$ & $\begin{array}{l}\text { mean } \\
\mathrm{pCi} / \mathrm{mL}\end{array}$ & $\begin{array}{r}\text { error } \\
1 \text { sigma } \\
\end{array}$ \\
\hline jan 7 & 0 & 125.29 & 3.25 \\
\hline $\operatorname{jan} 7$ & 100 & 111.58 & \\
\hline jan 7 & 200 & 125.80 & 11.84 \\
\hline jan 7 & 300 & 111.53 & 10.87 \\
\hline $\operatorname{jan} 7$ & 500 & 119.42 & 26.25 \\
\hline jan 7 & 600 & 115.53 & 15.78 \\
\hline jan 7 & 700 & 100.64 & 23.34 \\
\hline jan 7 & 800 & 121.49 & 1.14 \\
\hline $\operatorname{jan} 7$ & 900 & 118.19 & 7.71 \\
\hline $\operatorname{jan} 7$ & 1400 & 111.05 & 0.73 \\
\hline jan 7 & 2000 & 108.69 & 1.24 \\
\hline jan 8 & 200 & 102.67 & 1.70 \\
\hline jan 8 & 800 & 105.90 & 4.87 \\
\hline jan 8 & 1100 & 109.14 & 3.05 \\
\hline jan 8 & 1700 & 101.01 & 7.65 \\
\hline jan 8 & 2300 & 98.98 & 4.89 \\
\hline jan 9 & 500 & 94.80 & 0.12 \\
\hline jan 9 & 1100 & 95.74 & 6.87 \\
\hline jan 9 & 1200 & 91.59 & 9.21 \\
\hline jan 9 & 1300 & 96.59 & 0.78 \\
\hline jan 9 & 1400 & 91.84 & 3.46 \\
\hline jan 9 & 1430 & 92.87 & \\
\hline jan 9 & 2000 & 88.74 & 3.60 \\
\hline jan 10 & 200 & 86.78 & 2.33 \\
\hline jan 10 & 800 & 84.95 & 2.95 \\
\hline jan 10 & 1000 & 84.85 & 4.59 \\
\hline jan 10 & 1100 & 85.49 & 5.76 \\
\hline jan 10 & 1200 & 82.78 & 3.24 \\
\hline jan 10 & 1500 & 83.57 & 4.77 \\
\hline jan 10 & 2100 & 81.95 & 1.45 \\
\hline 1 & 300 & 89.78 & 0.64 \\
\hline & 900 & 75.62 & 2.70 \\
\hline & 1500 & 77.00 & 2.88 \\
\hline
\end{tabular}


Table B1. Steel Creek Survey (Page 7 of 7)

$\begin{array}{lrrr}\text { date } & \begin{array}{r}\text { time } \\ \text { midpoint }\end{array} & \begin{array}{r}\text { mean } \\ \text { pCi/mL }\end{array} & \begin{array}{r}\text { error } \\ \text { 1sigma }\end{array} \\ \text { jan 11 } & 2100 & 77.81 & 0.41 \\ \text { jan 12 } & 300 & 76.79 & 3.57 \\ \text { jan 12 } & & 900 & 72.98 \\ \text { jan 12 } & 1500 & 71.19 & 9.33 \\ \text { jan 12 } & 2100 & 79.31 & 2.23 \\ & & & \\ \text { jan 13 } & 300 & 69.76 & 3.14 \\ \text { jan 13 } & 900 & 64.18 & 2.21 \\ \text { jan 13 } & 1400 & 56.00 & 6.82 \\ \text { jan 13 } & 2000 & 58.32 & 1.68 \\ & & & \\ \text { jan 14 } & 200 & 53.74 & 0.42 \\ \text { jan 14 } & 800 & 54.78 & 0.81 \\ \text { jan 14 } & 1000 & 58.55 & 2.79 \\ \text { jan 14 } & 1200 & 71.71 & 0.20 \\ \text { ian 14 } & 1500 & 71.21 & 5.23 \\ \text { jan 14 } & 1800 & 72.52 & 1.03 \\ \text { jan 14 } & 2100 & 73.72 & 3.13 \\ \text { jan 15 } & & & \\ \text { jan 15 } & 300 & 74.73 & 0.16 \\ \text { jan 15 } & 600 & 78.26 & 3.18 \\ \text { jan 15 } & 900 & 76.37 & 0.25\end{array}$


Table B2. Highway 301 survey

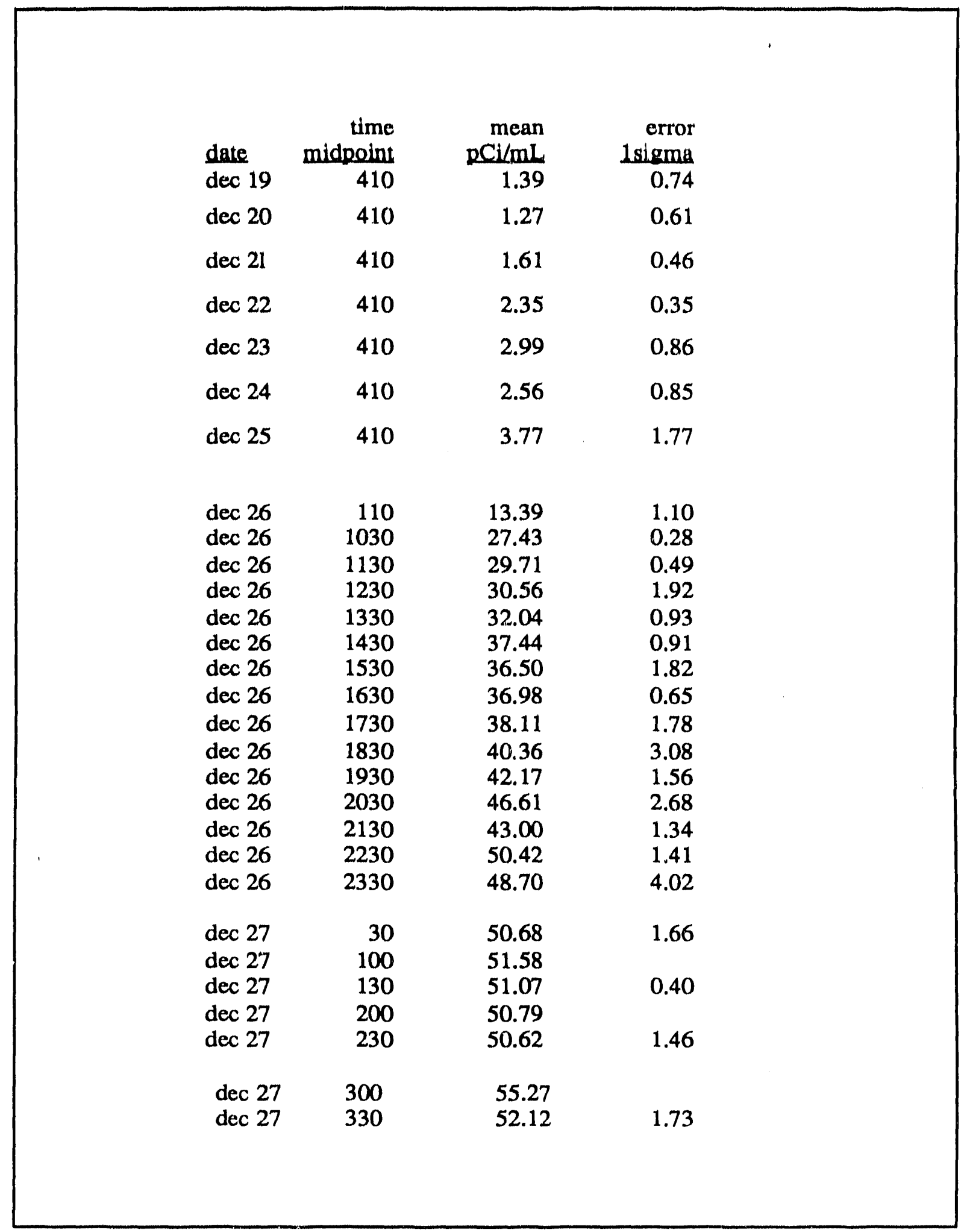


Table B2. Highway 301 survey (Page 2 of 9)

\begin{tabular}{|c|c|c|c|}
\hline date & $\begin{array}{r}\text { time } \\
\text { midpoint }\end{array}$ & $\begin{array}{r}\text { mean } \\
\mathrm{pCl} / \mathrm{mL}\end{array}$ & $\begin{array}{r}\text { error } \\
1 \text { sigma }\end{array}$ \\
\hline $\operatorname{dec} 27$ & 400 & 55.38 & \\
\hline $\operatorname{dec} 27$ & 430 & 50.91 & 1.19 \\
\hline $\operatorname{dec} 27$ & 500 & 59.51 & \\
\hline $\operatorname{dec} 27$ & 530 & 54.16 & 2.69 \\
\hline $\operatorname{dec} 27$ & 600 & 57.25 & \\
\hline $\operatorname{dec} 27$ & 630 & 54.07 & 1.46 \\
\hline $\operatorname{dec} 27$ & 700 & 58.94 & \\
\hline $\operatorname{dec} 27$ & 730 & 51.07 & 4.22 \\
\hline dec 27 & 800 & 59.71 & \\
\hline $\operatorname{dec} 27$ & 830 & 52.26 & 1.76 \\
\hline $\operatorname{dec} 27$ & 930 & 47.22 & 3.07 \\
\hline $\operatorname{dec} 27$ & 1000 & 60.28 & \\
\hline $\operatorname{dec} 27$ & 1030 & 55.93 & 4.31 \\
\hline $\operatorname{dec} 27$ & 1100 & 59.07 & \\
\hline $\operatorname{dec} 27$ & 1130 & 59.16 & 0.23 \\
\hline $\operatorname{dec} 27$ & 1330 & 57.84 & 3.66 \\
\hline $\operatorname{dec} 27$ & 1530 & 61.79 & 0.88 \\
\hline $\operatorname{dec} 27$ & 1730 & 60.47 & 5.54 \\
\hline $\operatorname{dec} 27$ & 1830 & 59.99 & 0.16 \\
\hline $\operatorname{dec} 27$ & 1930 & 60.73 & 5.29 \\
\hline $\operatorname{dec} 27$ & 2030 & 61.49 & 2.89 \\
\hline $\operatorname{dec} 27$ & 2130 & 62.89 & 2.90 \\
\hline $\operatorname{dec} 27$ & 2230 & 60.74 & 4.31 \\
\hline $\operatorname{dec} 27$ & 2330 & 61.32 & 3.73 \\
\hline $\operatorname{dec} 28$ & 30 & 56.81 & \\
\hline $\operatorname{dec} 28$ & 130 & 59.77 & 1.29 \\
\hline $\operatorname{dec} 28$ & 230 & 66.85 & \\
\hline $\operatorname{dec} 28$ & 330 & 61.51 & 2.14 \\
\hline $\operatorname{dec} 28$ & 430 & 57.80 & \\
\hline $\operatorname{dec} 28$ & 530 & 58.71 & 5.73 \\
\hline $\operatorname{dec} 28$ & 630 & 54.84 & \\
\hline $\operatorname{dec} 28$ & 730 & 56.46 & 3.15 \\
\hline $\operatorname{dec} 28$ & 830 & 55.75 & \\
\hline $\operatorname{dec} 28$ & 900 & 54.19 & 0.75 \\
\hline $\operatorname{dec} 28$ & 1000 & 54.12 & 0.11 \\
\hline $\operatorname{dec} 28$ & 1100 & 53.69 & 4.61 \\
\hline $\operatorname{dec} 28$ & 1200 & 54.37 & 3.37 \\
\hline
\end{tabular}


Table B2. Highway 301 survey (Page 3 of 9)

\begin{tabular}{|c|c|c|c|}
\hline date & $\begin{array}{r}\text { time } \\
\text { midpoint }\end{array}$ & $\underset{\mathrm{pCl} / \mathrm{mL}}{\operatorname{mean}}$ & $\begin{array}{r}\text { error } \\
\text { sigma }\end{array}$ \\
\hline $\operatorname{dec} 28$ & 1300 & 55.49 & 3.20 \\
\hline $\operatorname{dec} 28$ & 1400 & 55.02 & 2.26 \\
\hline $\operatorname{dec} 28$ & 1500 & 55.62 & 0.45 \\
\hline $\operatorname{dec} 28$ & 1600 & 56.13 & 4.49 \\
\hline $\operatorname{dec} 28$ & 1700 & 51.18 & 2.08 \\
\hline $\operatorname{dec} 28$ & 1800 & 50.67 & \\
\hline $\operatorname{dec} 28$ & 1900 & 48.13 & \\
\hline $\operatorname{dec} 28$ & 2000 & 53.40 & \\
\hline $\operatorname{dec} 28$ & 2100 & 55.73 & 1.98 \\
\hline $\operatorname{dec} 28$ & 2300 & 51.21 & 1.46 \\
\hline $\operatorname{dec} 29$ & 100 & 51.90 & 3.85 \\
\hline $\operatorname{dec} 29$ & 300 & 51.71 & 3.27 \\
\hline $\operatorname{dec} 29$ & 500 & 50.55 & 1.23 \\
\hline $\operatorname{dec} 29$ & 700 & 51.52 & 1.82 \\
\hline $\operatorname{dec} 29$ & 900 & 48.58 & 2.18 \\
\hline $\operatorname{dec} 29$ & 1100 & 45.94 & 0.87 \\
\hline $\operatorname{dec} 29$ & 1300 & 42.31 & \\
\hline $\operatorname{dec} 29$ & 1500 & 47.18 & \\
\hline $\operatorname{dec} 29$ & 1700 & 42.48 & \\
\hline $\operatorname{dec} 29$ & 1800 & 42.06 & \\
\hline $\operatorname{dec} 29$ & 1900 & 38.62 & 1.97 \\
\hline $\operatorname{dec} 29$ & 2000 & 42.23 & \\
\hline $\operatorname{dec} 29$ & 2100 & 42.65 & \\
\hline $\operatorname{dec} 29$ & 2200 & 42.02 & \\
\hline $\operatorname{dec} 30$ & 0 & 39.37 & \\
\hline $\operatorname{dec} 30$ & 200 & 38.01 & \\
\hline $\operatorname{dec} 30$ & 300 & 33.77 & \\
\hline $\operatorname{dec} 30$ & .500 & 37.09 & 2.68 \\
\hline $\operatorname{dec} 30$ & 600 & 34.04 & 0.02 \\
\hline $\operatorname{dec} 30$ & 730 & 34.65 & \\
\hline $\operatorname{dec} 30$ & 830 & 34.15 & \\
\hline $\operatorname{dec} 30$ & 900 & 34.43 & \\
\hline $\operatorname{dec} 30$ & 930 & 41.57 & 2.75 \\
\hline $\operatorname{dec} 30$ & 1000 & 30.83 & 0.82 \\
\hline $\operatorname{dec} 30$ & 1030 & 48.95 & 1.57 \\
\hline $\operatorname{dec} 30$ & 1100 & 32.25 & \\
\hline
\end{tabular}


Table B2. Highway 301 survoy (Page 4 of 9)

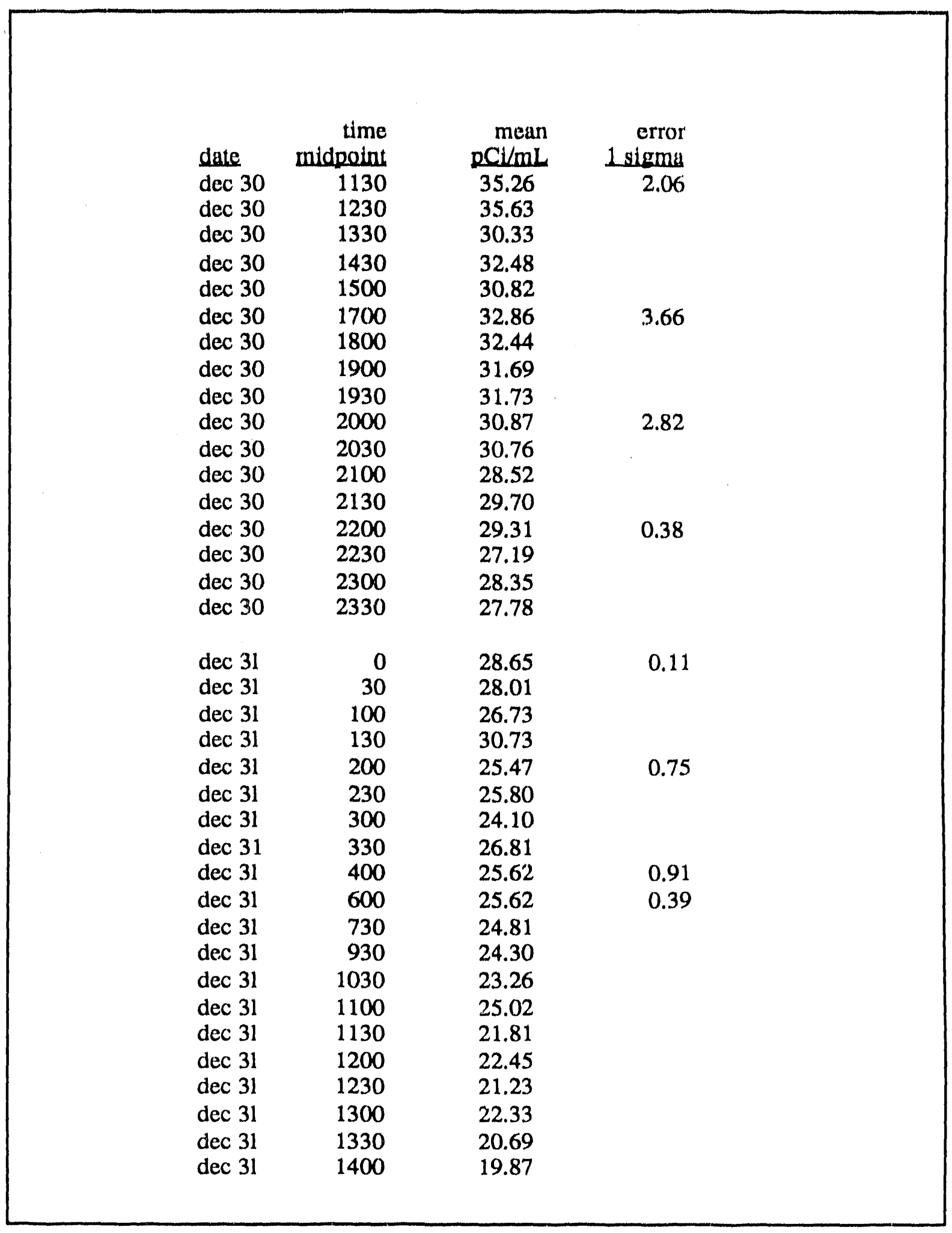


Table 132. Highway 301 survoy (Pago 5 of 9)

\begin{tabular}{|c|c|c|c|}
\hline date & $\begin{array}{r}\text { time } \\
\text { midpoint }\end{array}$ & $\begin{array}{c}\text { mean } \\
\text { pCi/mal }\end{array}$ & $\begin{array}{r}\text { crror } \\
\text { L slawas }\end{array}$ \\
\hline $\operatorname{dec} 31$ & 1430 & 19.17 & 0.88 \\
\hline $\operatorname{dec} 31$ & 1500 & 19.89 & \\
\hline $\operatorname{dec} 31$ & 1530 & 20.58 & 0.48 \\
\hline $\operatorname{dec} 31$ & 1600 & 19.56 & \\
\hline $\operatorname{dec} 31$ & 1630 & 19.75 & \\
\hline $\operatorname{dec} 31$ & 1700 & 19.03 & \\
\hline $\operatorname{dec} 31$ & 1730 & 20.55 & 0.30 \\
\hline $\operatorname{dec} 31$ & 1800 & 19.26 & \\
\hline $\operatorname{dec} 31$ & 1830 & 20.00 & \\
\hline $\operatorname{dec} 31$ & 1900 & 20.29 & \\
\hline $\operatorname{dec} 31$ & 1930 & 20.09 & 0.14 \\
\hline $\operatorname{dec} 31$ & 2000 & 18.30 & \\
\hline $\operatorname{dec} 31$ & 2030 & 16.40 & \\
\hline $\operatorname{dec} 31$ & 2100 & 16.07 & \\
\hline $\operatorname{dec} 31$ & 2130 & 21.37 & 2.69 \\
\hline $\operatorname{dec} 31$ & 2230 & 17.98 & 0.69 \\
\hline $\operatorname{dec} 31$ & 2330 & 19.30 & 0.74 \\
\hline jan 1 & 30 & 17.34 & 2.84 \\
\hline jan 1 & 130 & 16.36 & 0.33 \\
\hline $\operatorname{jan} 1$ & 230 & 16.96 & 0.76 \\
\hline $\operatorname{jan} 1$ & 330 & 18.87 & 1.83 \\
\hline jan 1 & 430 & 16.16 & 2.71 \\
\hline jan 1 & 500 & 16.03 & 0.92 \\
\hline jan 1 & 530 & 15.70 & 1.47 \\
\hline jan 1 & 600 & 16.68 & 1.06 \\
\hline jan 1 & 800 & 15.49 & \\
\hline jan 1 & 900 & 16.97 & \\
\hline jan 1 & 1000 & 16.75 & \\
\hline jan 1 & 1200 & 15.02 & \\
\hline jan 1 & 1400 & 14.73 & \\
\hline jan 1 & 1500 & 12.59 & \\
\hline jan 1 & 1700 & 13.84 & 1.03 \\
\hline jan 1 & 1900 & 10.92 & \\
\hline jan 1 & 2100 & 11.44 & \\
\hline Jo & 900 & 8.49 & \\
\hline jan 2 & 1000 & 9.81 & \\
\hline
\end{tabular}


T'able 132. Highway 301 survoy (Pago 6 of 9)

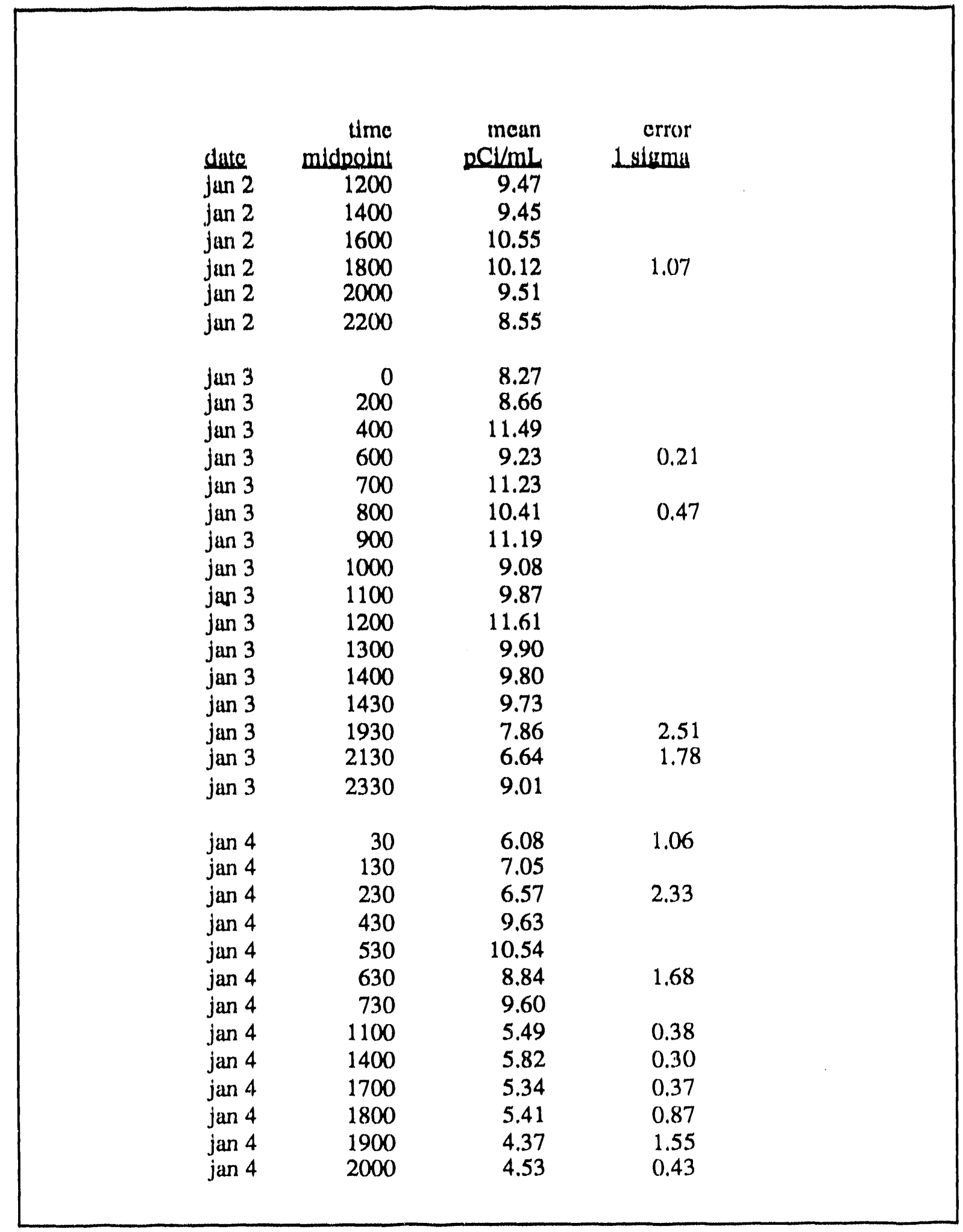


Tuble B2. Highway 301 survey (Page 7 of 9)

\begin{tabular}{|c|c|c|c|}
\hline \multirow{5}{*}{$\begin{array}{l}\text { date } \\
\text { jan } 4 \\
\text { Jan } 4 \\
\text { Jan } 4\end{array}$} & $\begin{array}{l}\text { time } \\
\text { midpoint }\end{array}$ & $\begin{array}{l}\text { mean } \\
\mathrm{pCi} / \mathrm{mL}\end{array}$ & $\begin{array}{r}\text { error } \\
1 \text { sigmg }\end{array}$ \\
\hline & 2100 & 5.20 & 0.36 \\
\hline & 2200 & 5.24 & 0.04 \\
\hline & 2300 & 5.43 & \\
\hline & & 5.43 & \\
\hline jan 5 & 0 & 6.95 & 2.59 \\
\hline jan 5 & 100 & 4.47 & \\
\hline jan 5 & 200 & 5.22 & 1.33 \\
\hline jan 5 & 300 & 4.77 & \\
\hline jan 5 & 400 & 5.05 & 0.18 \\
\hline jan 5 & 500 & 5.67 & \\
\hline jan 5 & 600 & 4.85 & 0.73 \\
\hline jan 5 & 700 & 5.57 & 0.25 \\
\hline jan 5 & 800 & 5.53 & 2.26 \\
\hline an 5 & 900 & 5.40 & 1.10 \\
\hline jan 5 & 1000 & 5.96 & 0.64 \\
\hline jan 5 & 1100 & 5.93 & \\
\hline jan 5 & 1200 & 5.11 & 0.47 \\
\hline jan 5 & 1300 & 5.64 & \\
\hline jan 5 & 1400 & 5.69 & 1.20 \\
\hline jan 5 & 1500 & 4.77 & \\
\hline jan 5 & 1600 & 5.06 & 0.54 \\
\hline jan 5 & 1700 & 6.22 & \\
\hline jan 5 & 1800 & 4.74 & 0.28 \\
\hline jan 5 & 1900 & 5.15 & 0.69 \\
\hline jan 5 & 2000 & 5.36 & 0.06 \\
\hline jan 5 & 2100 & 5.10 & \\
\hline jan 5 & 2200 & 5.83 & 0.87 \\
\hline jan 5 & 2300 & 4.76 & \\
\hline jan 6 & 0 & 4.56 & 0.09 \\
\hline jan 6 & 100 & 5.25 & \\
\hline jan 6 & 200 & 4.73 & 0.69 \\
\hline jan 6 & 300 & 3.78 & \\
\hline jan 6 & 400 & 3.31 & 0.81 \\
\hline jan 6 & 500 & 2.92 & \\
\hline jan 6 & 600 & 3.77 & \\
\hline jan 6 & 800 & 3.85 & 0.73 \\
\hline jan 6 & 900 & 4.85 & 0.68 \\
\hline
\end{tabular}


Table B2. Highway 301 survey (Page 8 of 9)

\begin{tabular}{lrrr} 
date & $\begin{array}{r}\text { time } \\
\text { midpoint }\end{array}$ & $\begin{array}{r}\text { mean } \\
\text { pCi/mL }\end{array}$ & $\begin{array}{r}\text { error } \\
\text { 1sigma }\end{array}$ \\
jan 6 & 1000 & 3.57 & \\
jan 6 & 1100 & 3.23 & 0.67 \\
jan 6 & 1200 & 3.17 & 1.27 \\
jan 6 & 1300 & 2.68 & 0.30 \\
jan 6 & 1400 & 3.47 & 0.33 \\
jan 6 & 1500 & 3.12 & 0.95 \\
jan 6 & 1600 & 3.57 & 1.02 \\
jan 6 & 1700 & 4.03 & 0.43 \\
jan 6 & 1800 & 4.20 & 0.66 \\
jan 6 & 1900 & 4.94 & 0.60 \\
jan 6 & 2000 & 4.56 & 1.22 \\
jan 6 & 2100 & 4.51 & 0.44 \\
jan 6 & 2200 & 4.81 & 0.98 \\
jan 6 & 2300 & 3.93 & 1.00 \\
& & & \\
jan 7 & 0 & 4.79 & 0.08 \\
jan 7 & 100 & 5.55 & 0.60 \\
jan 7 & 200 & 3.92 & 0.92 \\
jan 7 & 300 & 5.46 & 0.38 \\
jan 7 & 400 & 4.98 & 0.43 \\
jan 7 & 500 & 4.18 & 0.70 \\
jan 7 & 600 & 5.55 & 0.69 \\
jan 7 & 630 & 4.92 & 0.85 \\
jan 7 & 1230 & 4.23 & 0.69 \\
jan 7 & 1830 & 3.98 & 0.28 \\
jan 8 & 30 & 5.40 & 0.81 \\
jan 8 & 630 & 7.74 & 0.82 \\
jan 8 & 930 & 6.29 & 0.53 \\
jan 8 & 1530 & 2.90 & 0.03 \\
jan 8 & 2130 & 3.15 & 0.37 \\
jan 9 & 330 & 5.36 & 0.26 \\
jan 9 & 430 & 5.87 & \\
jan 9 & 930 & 5.12 & \\
jan 9 & 1030 & 7.34 & 1.93 \\
jan 9 & 1130 & 6.53 & 0.92 \\
jan 9 & 1230 & 6.81 & 1.36 \\
& & & \\
\hline
\end{tabular}


Table B2. Highway 301 survey (Page 9 of 9)

\begin{tabular}{|c|c|c|c|}
\hline date & $\begin{array}{r}\text { time } \\
\text { midpoint }\end{array}$ & $\begin{array}{r}\text { mean } \\
\mathrm{pCi} / \mathrm{mL}\end{array}$ & $\begin{array}{r}\text { error } \\
1 \text { sigma }\end{array}$ \\
\hline $\operatorname{jan} 9$ & 1830 & 4.54 & 0.54 \\
\hline jan 10 & 230 & 2.67 & 0.59 \\
\hline jan 10 & 830 & 3.86 & 0.82 \\
\hline jan 10 & 930 & 3.37 & 0.99 \\
\hline jan 10 & 1030 & 2.59 & 0.28 \\
\hline jan 10 & 1300 & 3.40 & 1.37 \\
\hline jan 10 & 1900 & 6.98 & 0.12 \\
\hline $\operatorname{jan} 11$ & 100 & 4.42 & 0.37 \\
\hline jan 11 & 700 & 3.31 & 2.25 \\
\hline jan 11 & 1300 & 3.84 & 1.63 \\
\hline jan 11 & 1900 & 4.24 & 0.37 \\
\hline jan 12 & 100 & 4.09 & 0.09 \\
\hline jan 12 & 700 & 5.03 & 0.58 \\
\hline jan 12 & 1000 & 2.20 & \\
\hline jan 12 & 1300 & 4.57 & \\
\hline jan 12 & 1900 & 3.29 & 0.26 \\
\hline jan 13 & 100 & 1.99 & 0.93 \\
\hline jan 13 & 700 & 3.53 & 0.32 \\
\hline jan 13 & 1230 & 2.46 & 0.36 \\
\hline jan 13 & 1530 & 1.84 & 0.37 \\
\hline jan 13 & 2130 & 2.35 & 1.07 \\
\hline jan 14 & 330 & 3.42 & 0.42 \\
\hline jan 14 & 930 & 3.25 & 0.99 \\
\hline jan 14 & 1100 & 3.60 & 0.67 \\
\hline jan 14 & 1400 & 4.00 & 0.30 \\
\hline jan 14 & 1700 & 3.87 & 0.13 \\
\hline jan 14 & 2000 & 4.65 & 0.44 \\
\hline jan 14 & 2300 & 3.49 & 0.54 \\
\hline jan 15 & 0 & 3.89 & 0.68 \\
\hline jan 15 & 500 & 3.32 & 0.91 \\
\hline jan 15 & 600 & 3.48 & 1.45 \\
\hline jan 15 & 1100 & 4.01 & 0.49 \\
\hline
\end{tabular}


Table B3. Becks Ferry survey (Page 1 of 9)

\begin{tabular}{|c|c|c|c|}
\hline$\frac{\text { date }}{\operatorname{dec} 28}$ & $\begin{array}{r}\begin{array}{r}\text { time } \\
\text { midpoint }\end{array} \\
100\end{array}$ & $\begin{array}{c}\begin{array}{c}\text { mean } \\
\mathrm{DCi} / \mathrm{mL}\end{array} \\
4.41\end{array}$ & $\begin{array}{r}\text { error } \\
1 \text { sigma }\end{array}$ \\
\hline $\begin{array}{l}\operatorname{dec} 28 \\
\operatorname{dec} 28\end{array}$ & $\begin{array}{l}300 \\
500\end{array}$ & $\begin{array}{l}2.57 \\
3.30\end{array}$ & \\
\hline $\operatorname{dec} 28$ & 1030 & 17.15 & 0.84 \\
\hline $\begin{array}{l}\operatorname{dec} 28 \\
\operatorname{dec} 28\end{array}$ & $\begin{array}{l}1230 \\
1345\end{array}$ & $\begin{array}{l}18.18 \\
21.01\end{array}$ & $\begin{array}{l}0.79 \\
0.32\end{array}$ \\
\hline $\begin{array}{l}\operatorname{dec} 28 \\
\operatorname{dec} 28\end{array}$ & $\begin{array}{l}1400 \\
1430\end{array}$ & $\begin{array}{l}21.54 \\
24.08\end{array}$ & $\begin{array}{l}1.12 \\
3.87\end{array}$ \\
\hline $\operatorname{dec} 28$ & 1600 & 24.10 & \\
\hline $\operatorname{dec} 23$ & 1630 & 24.82 & 0.54 \\
\hline $\operatorname{dec} 28$ & 1700 & 23.84 & 1.08 \\
\hline $\operatorname{dec} 28$ & 1830 & 28.32 & 4.41 \\
\hline $\operatorname{dec} 28$ & 1900 & 27.10 & 0.53 \\
\hline $\operatorname{dec} 28$ & 2030 & 28.51 & 0.78 \\
\hline $\operatorname{dec} 28$ & 2100 & 30.82 & 2.95 \\
\hline $\operatorname{dec} 28$ & 2230 & 34.83 & 1.31 \\
\hline $\operatorname{dec} 28$ & 2300 & 38.98 & 1.05 \\
\hline $\operatorname{dec} 29$ & 0 & 38.81 & \\
\hline $\operatorname{dec} 29$ & 30 & 36.89 & \\
\hline $\operatorname{dec} 29$ & 100 & 35.16 & \\
\hline $\operatorname{dec} 29$ & 130 & 35.82 & \\
\hline $\operatorname{dec} 29$ & 230 & 39.67 & 1.73 \\
\hline $\begin{array}{l}\operatorname{dec} 29 \\
\operatorname{dec} 29\end{array}$ & $\begin{array}{l}330 \\
430\end{array}$ & $\begin{array}{l}39.07 \\
42.12\end{array}$ & 3.60 \\
\hline $\operatorname{dec} 29$ & 530 & 40.51 & \\
\hline $\operatorname{dec} 29$ & 600 & 48.5 & \\
\hline $\operatorname{dec} 29$ & 630 & 46.69 & 0.39 \\
\hline $\operatorname{dec} 29$ & 700 & 49.3 & \\
\hline $\operatorname{dec} 29$ & 730 & 46.63 & \\
\hline $\operatorname{dec} 29$ & 730 & 50.6 & \\
\hline $\operatorname{dec} 29$ & 900 & 45.14 & 1.34 \\
\hline $\operatorname{dec} 29$ & 1030 & 45.49 & \\
\hline $\operatorname{dec} 29$ & 1130 & 46.48 & 1.47 \\
\hline $\operatorname{dec} 29$ & 1230 & 47.79 & \\
\hline $\operatorname{dec} 29$ & 1330 & 49.78 & 0.25 \\
\hline
\end{tabular}


Table B3. Becks Ferry survey (Page 2 of 9)

\begin{tabular}{|c|c|c|c|}
\hline date & $\begin{array}{r}\text { time } \\
\text { midpoint }\end{array}$ & $\begin{array}{r}\text { mean } \\
\mathrm{pCi} / \mathrm{mL}\end{array}$ & $\begin{array}{r}\text { error } \\
1 \text { sigma }\end{array}$ \\
\hline $\operatorname{dec} 29$ & 1700 & 54.35 & 4.91 \\
\hline $\operatorname{dec} 29$ & 1900 & 55.49 & 1.70 \\
\hline $\operatorname{dec} 29$ & 2100 & 51.71 & \\
\hline $\operatorname{dec} 29$ & 2100 & 50.9 & \\
\hline $\operatorname{dec} 29$ & 2200 & 49.99 & \\
\hline $\operatorname{dec} 29$ & 2300 & 52.54 & 3.85 \\
\hline $\operatorname{dec} 30$ & & 0 & 54.67 \\
\hline $\operatorname{dec} 30$ & & 100 & 55.37 \\
\hline $\operatorname{dec} 30$ & 300 & 55.62 & 5.06 \\
\hline $\operatorname{dec} 30$ & 500 & 56.17 & \\
\hline $\operatorname{dec} 30$ & 700 & 53.65 & \\
\hline $\operatorname{dec} 30$ & 700 & 52.0 & \\
\hline $\operatorname{dec} 30$ & 900 & 46.76 & \\
\hline $\operatorname{dec} 30$ & 1100 & 47.36 & 3.06 \\
\hline $\operatorname{dec} 30$ & 1300 & 47.51 & \\
\hline $\operatorname{dec} 30$ & 1300 & 49.2 & \\
\hline $\operatorname{dec} 30$ & 1400 & 50.36 & \\
\hline $\operatorname{dec} 30$ & 1400 & 46.9 & \\
\hline $\operatorname{dec} 30$ & 1500 & 48.43 & \\
\hline $\operatorname{dec} 30$ & 1500 & 46.6 & \\
\hline $\operatorname{dec} 30$ & 1600 & 51.06 & 3.92 \\
\hline $\operatorname{dec} 30$ & 1600 & 45.6 & \\
\hline $\operatorname{dec} 30$ & 1700 & 51.6 & \\
\hline $\operatorname{dec} 30$ & 1700 & 45.57 & \\
\hline $\operatorname{dec} 30$ & 1800 & 47.15 & \\
\hline $\operatorname{dec} 30$ & 1900 & 51.50 & \\
\hline $\operatorname{dec} 30$ & 2000 & 50.21 & 3.83 \\
\hline $\operatorname{dec} 30$ & 2100 & 45.6 & \\
\hline $\operatorname{dec} 30$ & 2130 & 43.75 & \\
\hline $\operatorname{dec} 30$ & 2200 & 52.99 & 1.93 \\
\hline $\operatorname{dec} 31$ & 0 & 47.62 & 3.25 \\
\hline $\operatorname{dec} 31$ & 200 & 48.11 & \\
\hline ec 31 & 400 & 52.41 & 1.87 \\
\hline ec 31 & 600 & 49.19 & \\
\hline c 31 & 600 & 47.6 & \\
\hline
\end{tabular}


Table B3. Becks Ferry survey (Page 3 of 9)

\begin{tabular}{|c|c|c|c|}
\hline date & $\begin{array}{r}\text { time } \\
\text { midpoint }\end{array}$ & $\begin{array}{r}\text { mean } \\
\mathrm{pCi} / \mathrm{mL}\end{array}$ & $\begin{array}{r}\text { error } \\
1 \text { sigma } \\
072\end{array}$ \\
\hline $\operatorname{dec} 31$ & 700 & 46.02 & 0.72 \\
\hline $\begin{array}{l}\operatorname{dec} 31 \\
\operatorname{dec} 31 \\
\operatorname{dec} 31\end{array}$ & $1000^{1000}$ & $\begin{array}{r}47.29 \\
47.83 \\
45.5\end{array}$ & 2.98 \\
\hline $\begin{array}{l}\operatorname{dec} 31 \\
\operatorname{dec} 31\end{array}$ & $1100^{1100}$ & $\begin{array}{r}47.07 \\
42.5\end{array}$ & \\
\hline $\operatorname{dec} 31$ & 1200 & 46.84 & 0.32 \\
\hline $\begin{array}{l}\operatorname{dec} 31 \\
\operatorname{dec} 31\end{array}$ & ${ }_{1300}$ & $\begin{array}{r}42.5 \\
47.28\end{array}$ & \\
\hline $\operatorname{dec} 31$ & 1300 & $\begin{array}{r}42.5 \\
4422\end{array}$ & \\
\hline $\begin{array}{l}\operatorname{dec} 31 \\
\operatorname{dec} 31\end{array}$ & $1400^{1400}$ & $\begin{array}{r}44.32 \\
43.8\end{array}$ & 2.72 \\
\hline $\operatorname{dec} 31$ & 1500 & 44.99 & 0.74 \\
\hline $\operatorname{dec} 31$ & 1600 & 45.00 & 1.73 \\
\hline $\operatorname{dec} 31$ & 1700 & 39.22 & \\
\hline $\operatorname{dec} 31$ & 1800 & 42.88 & \\
\hline $\begin{array}{l}\operatorname{dec} 31 \\
\operatorname{dec} 31\end{array}$ & ${ }_{1900}^{1900}$ & $\begin{array}{r}38.7 \\
39.77\end{array}$ & 1.8 \\
\hline $\begin{array}{l}\operatorname{dec} 3 \\
\operatorname{dec} 31 \\
\operatorname{dec} 31\end{array}$ & $\begin{array}{r}2000 \\
2000 \\
2100\end{array}$ & $\begin{array}{r}41.0 \\
36.78 \\
39.05\end{array}$ & \\
\hline $\operatorname{dec} 31$ & 2200 & 35.21 & \\
\hline $\operatorname{dec} 31$ & 2300 & 36.27 & \\
\hline jan 1 & 0 & 35.51 & \\
\hline an 1 & 100 & 36.62 & \\
\hline jan 1 & 200 & 37.58 & \\
\hline an 1 & 300 & 34.67 & \\
\hline jan 1 & 400 & 36.82 & \\
\hline jan 1 & 500 & 35.21 & \\
\hline jan 1 & 600 & 31.57 & \\
\hline $\begin{array}{l}\text { jan } 1 \\
\text { jan } 1\end{array}$ & 600 & $\begin{array}{r}33.6 \\
35.63\end{array}$ & \\
\hline jan 1 & 700 & 30.8 & \\
\hline jan 1 & 800 & $\begin{array}{l}32.06 \\
35.01\end{array}$ & \\
\hline an 1 & 1000 & 29.84 & \\
\hline
\end{tabular}


Table B3. Becks Ferry survey (Page 4 of 9)

\begin{tabular}{|c|c|c|c|}
\hline date & $\begin{array}{r}\text { time } \\
\text { midpoint }\end{array}$ & $\begin{array}{r}\text { mean } \\
\mathrm{pCi} / \mathrm{mL} \\
235\end{array}$ & $\begin{array}{r}\text { error } \\
1 \text { sigma } \\
\end{array}$ \\
\hline jan 1 & 1100 & 28.35 & \\
\hline jan 1 & 1200 & $\begin{array}{r}31.2 \\
30.43\end{array}$ & \\
\hline $\begin{array}{l}\text { jan } 1 \\
\text { jan } 1\end{array}$ & $\begin{array}{l}1200 \\
1300\end{array}$ & $\begin{array}{l}30.45 \\
30.65\end{array}$ & \\
\hline jan 1 & 1400 & 32.65 & \\
\hline jan 1 & 1500 & 30.18 & 2.47 \\
\hline jan 1 & 1600 & 31.75 & \\
\hline jan 1 & 1700 & 29.60 & \\
\hline jan 1 & 1800 & 28.42 & \\
\hline jan 1 & 1900 & 30.44 & \\
\hline jan 1 & 2000 & 30.04 & \\
\hline jan 1 & 2200 & 28.64 & \\
\hline jan 2 & 100 & 24.67 & \\
\hline jan 2 & 300 & 27.0 & \\
\hline jan 2 & 400 & 24.43 & 1.58 \\
\hline jan 2 & 400 & 28.0 & \\
\hline jan 2 & 445 & 23.67 & \\
\hline jan 2 & 445 & 25.0 & \\
\hline $\begin{array}{l}\text { jan } 2 \\
\text { jan } 2\end{array}$ & $\begin{array}{l}600 \\
800\end{array}$ & $\begin{array}{l}28.07 \\
23.17\end{array}$ & \\
\hline jan 2 & 845 & 24.21 & \\
\hline jan 2 & 900 & 22.8 & \\
\hline jan 2 & 1000 & 23.07 & 1.15 \\
\hline jan 2 & 1000 & 20.7 & \\
\hline jan 2 & 1100 & 21.7 & \\
\hline jan 2 & 1200 & 21.52 & \\
\hline jan 2 & 1400 & 22.68 & \\
\hline jan 2 & 1600 & 19.64 & \\
\hline jan 2 & 1700 & 21.40 & 0.78 \\
\hline jan 2 & 1800 & 18.52 & \\
\hline jan 2 & 2000 & 19.09 & \\
\hline jan 2 & 2100 & 19.74 & \\
\hline jan 2 & 2200 & 17.22 & \\
\hline jan 2 & 2300 & 17.89 & \\
\hline
\end{tabular}


Table B3. Becks Ferry survey (Page 5 of 9)

\begin{tabular}{|c|c|c|c|}
\hline date & $\begin{array}{r}\text { time } \\
\text { midpoint }\end{array}$ & $\begin{array}{r}\text { mean } \\
\mathrm{pCi} / \mathrm{mL}\end{array}$ & $\begin{array}{r}\text { error } \\
1 \text { sigma }\end{array}$ \\
\hline$\overline{j a n} 3$ & 0 & 16.61 & 2.33 \\
\hline jan 3 & 100 & 17.87 & \\
\hline $\begin{array}{l}\text { jan } 3 \\
\operatorname{jan} 3\end{array}$ & $\begin{array}{l}200 \\
300\end{array}$ & $\begin{array}{l}19.27 \\
13.54\end{array}$ & \\
\hline jan 3 & 300 & 16.6 & 0.9 \\
\hline jan 3 & 400 & 18.42 & \\
\hline jan 3 & 400 & 15.8 & 0.5 \\
\hline jan 3 & 445 & 16.04 & \\
\hline jan 3 & 445 & 14.6 & 0.1 \\
\hline jan 3 & 600 & 15.35 & 0.56 \\
\hline jan 3 & 800 & 14.60 & \\
\hline jan 3 & 900 & 14.85 & \\
\hline jan 3 & 1000 & 16.51 & \\
\hline jan 3 & 1100 & 15.13 & 1.13 \\
\hline jan 3 & 1200 & 15.94 & \\
\hline jan 3 & 1300 & 14.25 & \\
\hline jan 3 & 1400 & 12.77 & \\
\hline jan 3 & 1500 & 14.97 & \\
\hline jan 3 & 1600 & 15.24 & \\
\hline jan 3 & 1700 & 12.26 & 0.52 \\
\hline $\operatorname{jan} 3$ & 1700 & 12.7 & \\
\hline jan 3 & 1800 & 11.70 & 0.18 \\
\hline jan 3 & 1900 & 11.24 & 0.21 \\
\hline jan 3 & 2000 & 10.68 & 0.04 \\
\hline jan 3 & 2100 & 10.31 & 2.46 \\
\hline jan 3 & 2200 & 10.19 & \\
\hline jan 3 & 2300 & 11.48 & 0.16 \\
\hline jan 4 & 0 & 11.29 & 0.93 \\
\hline jan 4 & 100 & 11.70 & \\
\hline jan 4 & 200 & 9.78 & 0.59 \\
\hline jan 4 & 300 & 10.72 & \\
\hline jan 4 & 400 & 11.27 & 0.69 \\
\hline jan 4 & 500 & 10.68 & 0.74 \\
\hline jan 4 & 600 & 11.07 & \\
\hline jan 4 & 600 & 9.7 & \\
\hline jan 4 & 700 & 10.93 & 0.24 \\
\hline
\end{tabular}


Table B3. Becks Ferry survey (Page 6 of 9)

\begin{tabular}{|c|c|c|c|}
\hline date & $\begin{array}{r}\text { ime } \\
\text { midpoint }\end{array}$ & $\begin{array}{l}\text { mean } \\
\mathrm{pCi} / \mathrm{mL}\end{array}$ & $\begin{array}{l}\text { error } \\
1 \text { sigma } \\
\end{array}$ \\
\hline$\overline{\operatorname{jan} 4}$ & 700 & 7.4 & \\
\hline jan 4 & 800 & 9.02 & \\
\hline jan 4 & 900 & 8.05 & \\
\hline jan 4 & 1000 & 11.98 & \\
\hline jan 4 & 1100 & 7.75 & \\
\hline jan 4 & 1200 & 6.73 & \\
\hline jan 4 & 1300 & 8.71 & 0.05 \\
\hline jan 4 & 1400 & 8.62 & \\
\hline jan 4 & 1500 & 11.03 & 5.06 \\
\hline jan 4 & 1600 & 8.32 & \\
\hline $\operatorname{jan} 4$ & 1700 & 8.78 & 0.66 \\
\hline $\operatorname{jan} 4$ & 1700 & 8.4 & \\
\hline jan 4 & 1900 & 10.02 & \\
\hline $\operatorname{jan} 4$ & 2000 & 8.07 & 0.83 \\
\hline jan 4 & 2100 & 6.89 & 1.03 \\
\hline jan 4 & 2200 & $\begin{array}{l}8.63 \\
7.45\end{array}$ & \\
\hline jan 4 & 2300 & 7.45 & \\
\hline jan 5 & 0 & 7.79 & \\
\hline jan 5 & 100 & 7.62 & 2.09 \\
\hline jan 5 & 300 & 8.36 & \\
\hline jan 5 & 400 & 7.38 & \\
\hline jan 5 & 500 & 6.85 & 1.11 \\
\hline jan 5 & 600 & 7.90 & 1.73 \\
\hline jan 5 & 700 & 7.38 & \\
\hline jan 5 & 700 & 8.4 & \\
\hline jan 5 & 800 & 8.32 & \\
\hline jan 5 & 900 & 7.65 & 0.16 \\
\hline jan 5 & 1000 & 5.45 & \\
\hline jan 5 & 1100 & 8.04 & \\
\hline jan 5 & 1200 & 6.42 & \\
\hline jan 5 & 1300 & 6.54 & 0.40 \\
\hline jan 5 & 1400 & 6.05 & \\
\hline jan 5 & 1700 & 6.18 & \\
\hline jan 5 & 1700 & 8.2 & \\
\hline jan 5 & 1800 & 6.08 & 0.84 \\
\hline
\end{tabular}


Table B3. Becks Ferry survey (Page 7 of 9)

\begin{tabular}{|c|c|c|c|}
\hline date & $\begin{array}{r}\text { time } \\
\text { midpoint }\end{array}$ & $\begin{array}{l}\text { mean } \\
\mathrm{pCj} / \mathrm{mL}\end{array}$ & $\begin{array}{r}\text { error } \\
1 \text { sigma }\end{array}$ \\
\hline $\operatorname{jan} 5$ & 1900 & 6.24 & 1.70 \\
\hline jan 5 & 2000 & 6.06 & 0.33 \\
\hline jan 5 & 2100 & 7.31 & \\
\hline jan 5 & 2200 & 5.89 & 0.35 \\
\hline jan 5 & 2300 & 6.35 & 1.49 \\
\hline jan 6 & 0 & 6.01 & 0.59 \\
\hline jan 6 & 100 & 5.89 & 0.91 \\
\hline jan 6 & 200 & 6.04 & 1.29 \\
\hline jan 6 & 300 & 6.82 & 1.51 \\
\hline jan 6 & 400 & 6.26 & 0.02 \\
\hline $\operatorname{jan} 6$ & 500 & 5.65 & 1.02 \\
\hline jan 6 & 600 & 7.14 & 0.74 \\
\hline jan 6 & 600 & 7.0 & \\
\hline jan 6 & 700 & 7.03 & 1.32 \\
\hline jan 6 & 800 & 7.64 & 0.30 \\
\hline jan 6 & 900 & 6.74 & 0.07 \\
\hline jan 6 & 935 & 9.45 & \\
\hline jan 6 & 1500 & 5.67 & 0.28 \\
\hline jan 6 & 2100 & 5.26 & 0.81 \\
\hline $\operatorname{jan} 7$ & 300 & 5.14 & 0.10 \\
\hline jan 7 & 400 & 5.77 & 0.60 \\
\hline $\operatorname{jan} 7$ & 500 & 7.7 & \\
\hline $\operatorname{jan} 7$ & 900 & 4.62 & 0.01 \\
\hline jan 7 & 945 & 6.16 & 0.21 \\
\hline $\operatorname{jan} 7$ & 1000 & 6.14 & 1.23 \\
\hline $\operatorname{jan} 7$ & 1500 & 5.41 & 0.51 \\
\hline $\operatorname{jan} 7$ & 2100 & 6.40 & 1.26 \\
\hline jan 8 & 300 & 4.21 & 1.10 \\
\hline jan 8 & 515 & 5.1 & \\
\hline jan 8 & 900 & 6.62 & 4.31 \\
\hline jan 8 & 1300 & 4.44 & 1.03 \\
\hline jan 8 & 1900 & 3.76 & 0.62 \\
\hline
\end{tabular}


Table B3. Becks. Ferry survey (Page 8 of 9)

\begin{tabular}{|c|c|c|c|}
\hline date & $\begin{array}{r}\text { time } \\
\text { midpoint }\end{array}$ & $\begin{array}{l}\text { mean } \\
\mathrm{pCi} / \mathrm{mL}\end{array}$ & $\begin{array}{r}\text { error } \\
1 \text { sigma }\end{array}$ \\
\hline$\overline{\operatorname{jan} 9}$ & 100 & 4.51 & 0.64 \\
\hline jan 9 & 515 & 4.45 & 0.49 \\
\hline jan 9 & 515 & 3.6 & \\
\hline jan 9 & 700 & 4.67 & 0.23 \\
\hline $\operatorname{jan} 9$ & 900 & 6.03 & 1.07 \\
\hline jan 9 & 2100 & 5.27 & 0.61 \\
\hline $\operatorname{jan} 10$ & 100 & 7.52 & \\
\hline jan 10 & 700 & 8.1 & \\
\hline jan 10 & 900 & 6.02 & 1.70 \\
\hline jan 10 & 1300 & 5.22 & \\
\hline jan 10 & 1600 & 4.67 & \\
\hline $\operatorname{jan} 10$ & 2045 & 4.27 & \\
\hline jan 10 & 2200 & 10.36 & \\
\hline jan 11 & 400 & 6.36 & 0.95 \\
\hline jan 11 & 1000 & 6.70 & \\
\hline jan 11 & 1700 & 5.10 & 0.27 \\
\hline jan 11 & 2300 & 3.49 & 0.40 \\
\hline jan 12 & 500 & 3.96 & 0.77 \\
\hline jan 12 & 500 & nd & \\
\hline jan 12 & 1300 & 2.12 & 0.59 \\
\hline jan 12 & 1900 & 3.93 & 0.16 \\
\hline jan 13 & 100 & 4.02 & 0.72 \\
\hline jan 13 & 700 & 2.79 & 0.34 \\
\hline jan 13 & 935 & 3.41 & 0.26 \\
\hline jan 13 & 935 & 2.9 & \\
\hline jan 13 & 1300 & 3.23 & 0.67 \\
\hline jan 13 & 1900 & 2.54 & \\
\hline
\end{tabular}


Table B3. Becks Ferry survey (Page 9 of 9)

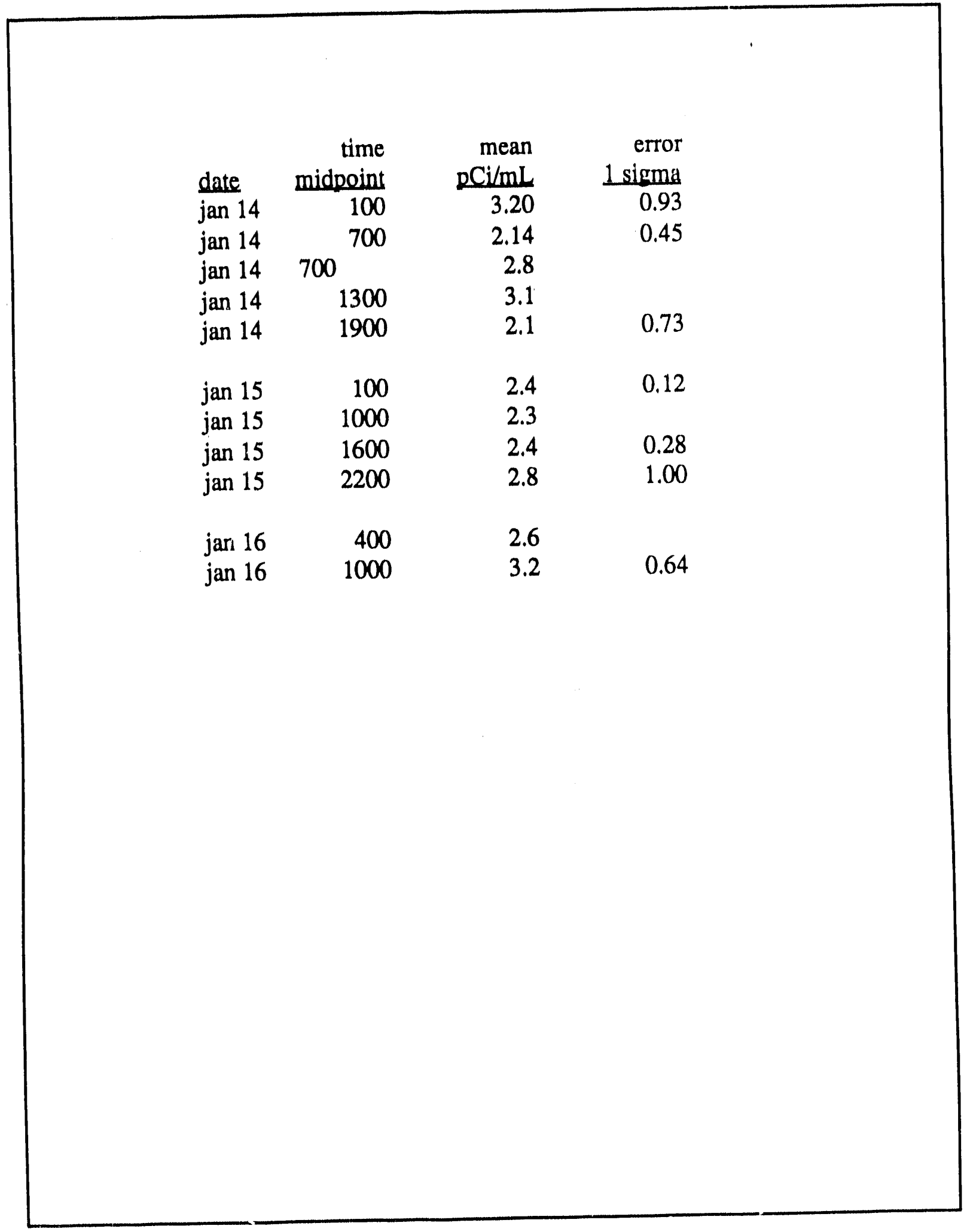


Table B4. Beaufort-Jasper canal survey before lift station (Page 1 of 2)

location

$200 \mathrm{yds}$ from river

400 yds from river

\begin{tabular}{lrrrr} 
date & \multicolumn{1}{c}{ time } & \multicolumn{1}{c}{$\mathrm{DCi} / \mathrm{mL}$} & crror \\
\cline { 4 - 5 } Jan 1 & & 1253 & 29.32 & \\
jan 2 & & 1300 & 24.70 & \\
jan 3 & & 1230 & 20.07 & \\
jan 4 & & 1335 & 16.19 & 1.30 \\
jan 4 & 1335 & & 19.6 & \\
jan 5 & & 1235 & 15.69 & \\
jan 5 & 1235 & & 17.2 & \\
jan 6 & & 1245 & 10.52 & 0.10 \\
jan 6 & 1245 & & 11.7 & \\
jan 7 & & 1015 & 5.19 & 0.32 \\
jan 7 & 1025 & & 5.2 & \\
jan 8 & & 1000 & 4.73 & \\
jan 8 & 1000 & & 4.4 & \\
jan 8 & & 1010 & 3.90 &
\end{tabular}

$\begin{array}{lrrll}\text { jan 1 } & & 1302 & 30.33 & \\ \text { jan 2 } & & 1305 & 22.64 & 1.21 \\ \text { jan 3 } & & 1235 & 20.70 & 0.71 \\ \text { jan 4 } & & 1330 & 16.59 & \\ \text { jan 4 } & 1330 & & 18.9 & \\ \text { jan 5 } & & 1240 & 16.61 & \\ \text { jan 5 } & 1240 & & 19.2 & \\ \text { jan 6 } & & 645 & 14.07 & \\ \text { jan 6 } & & 1250 & 13.71 & \\ \text { Jan 6 } & 1250 & & 15.3 & \\ \text { jan 7 } & & 1020 & 9.16 & 1.02 \\ \text { jan 7 } & 1020 & & 8.6 & \\ \text { jan 8 } & & 1010 & 5.29 & 1.80\end{array}$


Table B4. Beaufort-Jasper canal survey before lift station (Page 2 of 2)

lecation

end of canal at Black C.k.

100 yds before B-J Lift

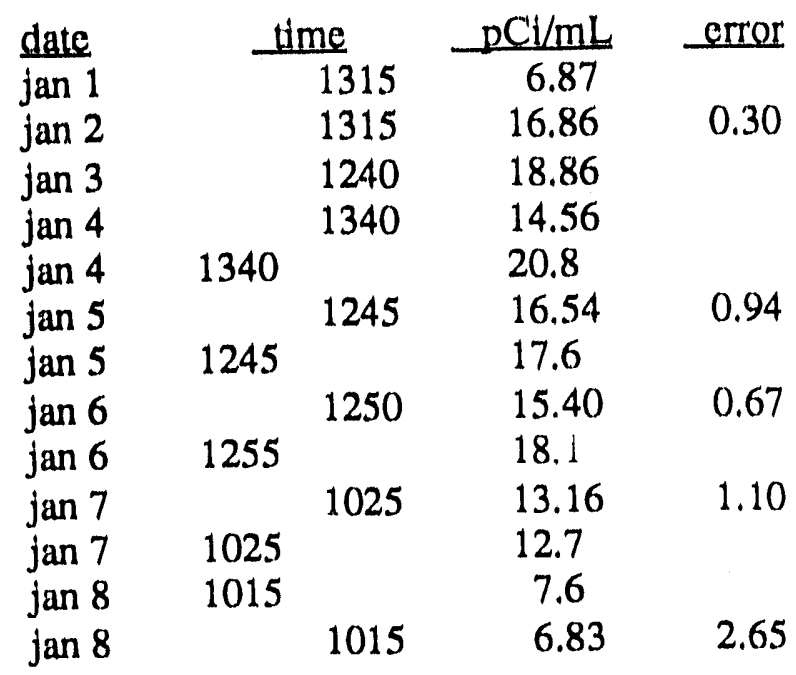

$\begin{array}{rrrrr}\text { Jan 1 } & & 1320 & 4.86 & 0.45 \\ \text { jan 2 } & & 1335 & 8.49 & \\ \text { Jan 3 } & & 1215 & 6.55 & 0.28 \\ \operatorname{jan} 4 & & 1310 & 8.03 & 1.22 \\ \operatorname{jan} 4 & 1310 & & 9.2 & \\ \text { jan 5 } & & 1215 & 8.66 & \\ \operatorname{jan} 5 & 1215 & & 9.0 & \\ \text { jan 6 } & & 1225 & 9.56 & 0.02 \\ \text { jan 6 } & 1300 & & 9.8 & \\ \text { jan 7 } & & 700 & 8.1 & 1.6 \\ \operatorname{Jan} 7 & & 1050 & 14.62 & 0.80 \\ \text { jan 7 } & 1050 & & 13.6 & \\ \text { jan 8 } & & 640 & 8.27 & \\ \text { jan 8 } & & 1035 & 7.56 & 1.39\end{array}$


Table B5. Beaufort-Jasper lift station survey (Page 1 of 4)

\begin{tabular}{|c|c|c|c|}
\hline $\begin{array}{l}\text { time } \\
\text { date } \\
\operatorname{dec} 28 \\
\operatorname{dec} 28 \\
\operatorname{dec} 28 \\
\operatorname{dec} 28 \\
\operatorname{dec} 28 \\
\operatorname{dec} 28\end{array}$ & $\begin{array}{c}\text { mean } \\
\text { midpoint } \\
100 \\
300 \\
500 \\
700 \\
900 \\
1100\end{array}$ & $\begin{array}{r}\begin{array}{r}\text { error } \\
\text { pCi/mL }\end{array} \\
3.66 \\
2.27 \\
2.62 \\
3.70 \\
4.12 \\
3.86\end{array}$ & $\begin{array}{r}1 \text { sigma } \\
1.07 \\
0.42 \\
0.96 \\
1.00 \\
0.62 \\
0.15\end{array}$ \\
\hline $\begin{array}{l}\operatorname{dec} 29 \\
\operatorname{dec} 29\end{array}$ & $\begin{array}{l}100 \\
500\end{array}$ & $\begin{array}{l}2.48 \\
2.39\end{array}$ & \\
\hline $\begin{array}{l}\operatorname{dec} 31 \\
\operatorname{dec} 31\end{array}$ & $\begin{array}{l}2130 \\
2330\end{array}$ & $\begin{array}{l}1.48 \\
2.54\end{array}$ & \\
\hline $\begin{array}{l}\text { jan } 1 \\
\text { jan } 1 \\
\text { jan } 1 \\
\text { jan } 1\end{array}$ & $\begin{array}{l}130 \\
330 \\
530 \\
730\end{array}$ & $\begin{array}{l}2.90 \\
4.26 \\
3.21 \\
1.47\end{array}$ & 1.97 \\
\hline $\begin{array}{l}\operatorname{jan} 2 \\
\operatorname{jan} 2\end{array}$ & $\begin{array}{l}1730 \\
2330\end{array}$ & $\begin{array}{l}2.53 \\
2.49\end{array}$ & 0.91 \\
\hline $\begin{array}{l}\operatorname{jan} 3 \\
\operatorname{jan} 3 \\
\operatorname{jan} 3 \\
\operatorname{jan} 3 \\
\operatorname{jan} 3\end{array}$ & $\begin{array}{r}330 \\
930 \\
1330 \\
1730 \\
2130\end{array}$ & $\begin{array}{l}2.11 \\
3.82 \\
2.47 \\
2.82 \\
2.67\end{array}$ & 0.19 \\
\hline $\begin{array}{l}\text { jan } 4 \\
\text { jan } 4\end{array}$ & $\begin{array}{l}130 \\
530\end{array}$ & $\begin{array}{l}3.89 \\
2.72\end{array}$ & 1.75 \\
\hline $\begin{array}{l}\text { jan } 6 \\
\text { jan } 6 \\
\text { jan } 6 \\
\text { jan } 6\end{array}$ & $\begin{array}{r}100 \\
1200\end{array}$ & $\begin{array}{r}7.2 \\
300 \\
6.6 \\
1225\end{array}$ & $\begin{array}{r}9.51 \\
1.6 \\
8.72\end{array}$ \\
\hline $\begin{array}{l}\text { jan } 6 \\
\text { jan } 6\end{array}$ & $\begin{array}{ll}1430 & \\
& 1500\end{array}$ & $\begin{array}{r}9.5 \\
9.22\end{array}$ & \\
\hline jan 6 & 1600 & 9.99 & 1.53 \\
\hline $\begin{array}{l}\text { jan } 6 \\
\text { jan } 6\end{array}$ & $\begin{array}{l}1700 \\
1800\end{array}$ & $\begin{array}{r}9.82 \\
10.50\end{array}$ & 0.23 \\
\hline $\begin{array}{l}\text { jan } 6 \\
\text { jan } 6\end{array}$ & $\begin{array}{l}1900 \\
2000\end{array}$ & $\begin{array}{l}12.17 \\
12.87\end{array}$ & 2.11 \\
\hline
\end{tabular}


Table B5. Beaufort-Jasper lift station survey (Page 2 of 4)

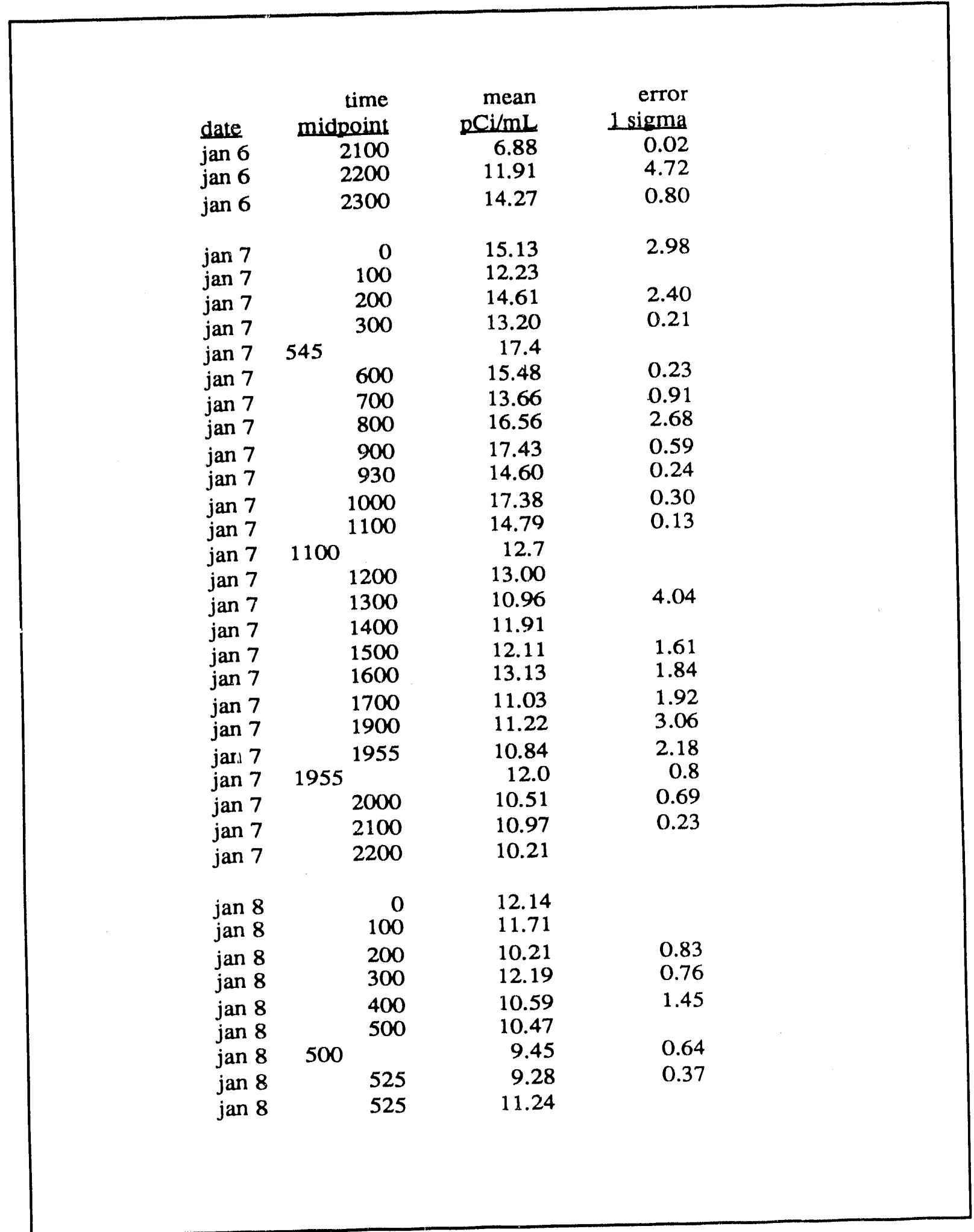


Table B5. Beaufort-Jasper lift station survey (Page 3 of 4)

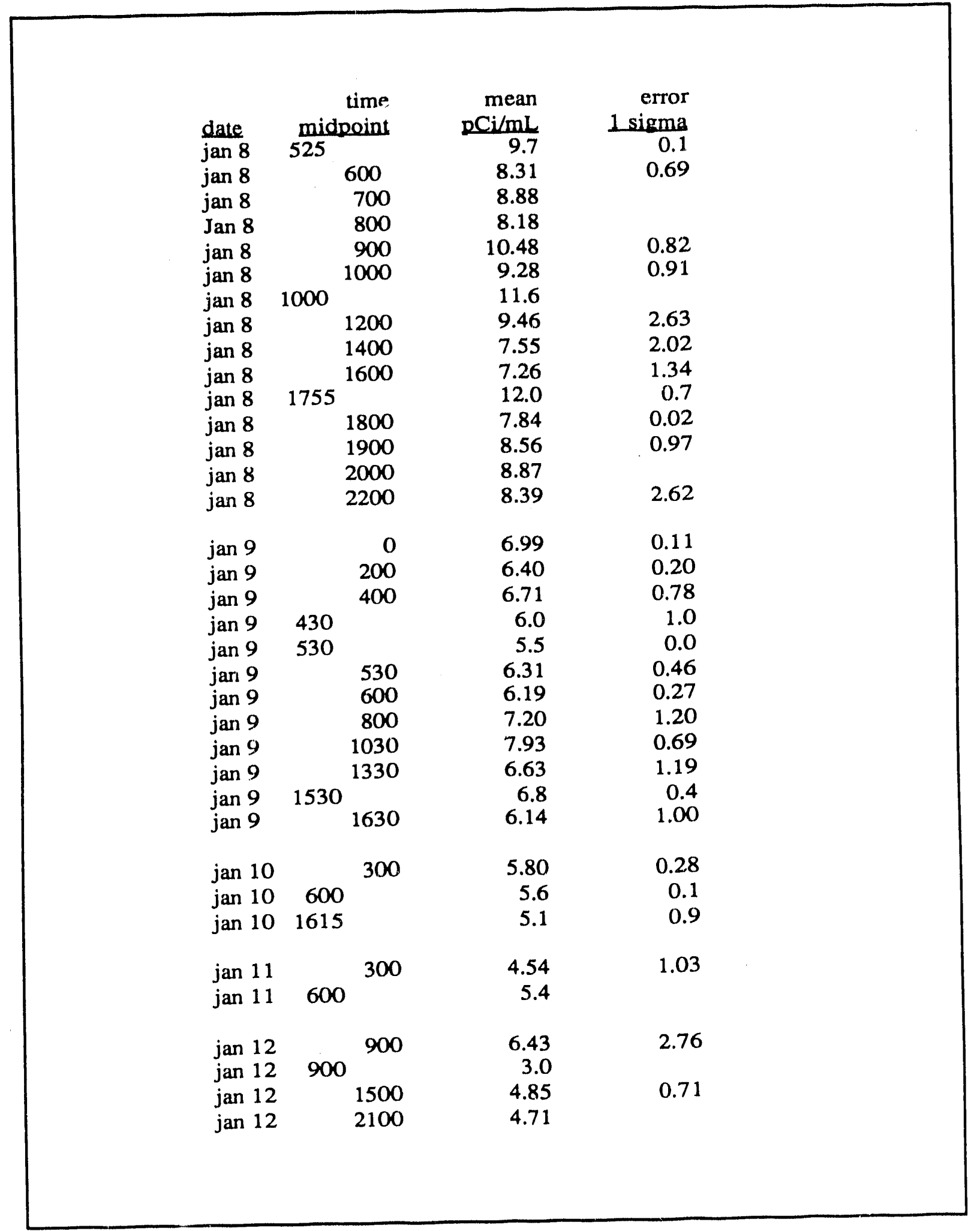


Table B5. Beaufort-Jasper lift station survey (Page 4 of 4)

\begin{tabular}{|c|c|c|c|}
\hline $\begin{array}{l}\text { time } \\
\text { date }\end{array}$ & $\begin{array}{c}\text { mean } \\
\text { midpoint }\end{array}$ & $\begin{array}{c}\text { error } \\
\mathrm{pCi} / \mathrm{mL}\end{array}$ & 1 sigma \\
\hline $\operatorname{jan} 13$ & 300 & 3.73 & 1.18 \\
\hline jan 13 & 900 & 4.00 & 0.79 \\
\hline jan 13 & 950 & 5.61 & \\
\hline jan 13 & 950 & 3.6 & \\
\hline jan 13 & 1500 & 3.27 & \\
\hline jan 13 & 2100 & 3.40 & 0.62 \\
\hline $\operatorname{jan} 14$ & 300 & 3.69 & 0.21 \\
\hline jan 14 & 300 & 3.2 & \\
\hline jan 14 & 900 & 3.26 & 0.62 \\
\hline jan 14 & 1500 & 4.08 & \\
\hline jan 14 & 2100 & 3.76 & 0.59 \\
\hline jan 15 & 300 & 4.47 & 0.81 \\
\hline jan 15 & 900 & 4.05 & \\
\hline jan 15 & 1500 & 2.91 & 0.47 \\
\hline jan 15 & 2100 & 2.40 & \\
\hline jan 16 & 300 & 3.39 & 0.28 \\
\hline jan 16 & 900 & 3.55 & \\
\hline
\end{tabular}


Table B6. Beaufort-Jasper canal survey after lift station (Page 1 of 5)

location

Highway 321 crossing

between Hwy 321 and 17

Highway 17 crossing

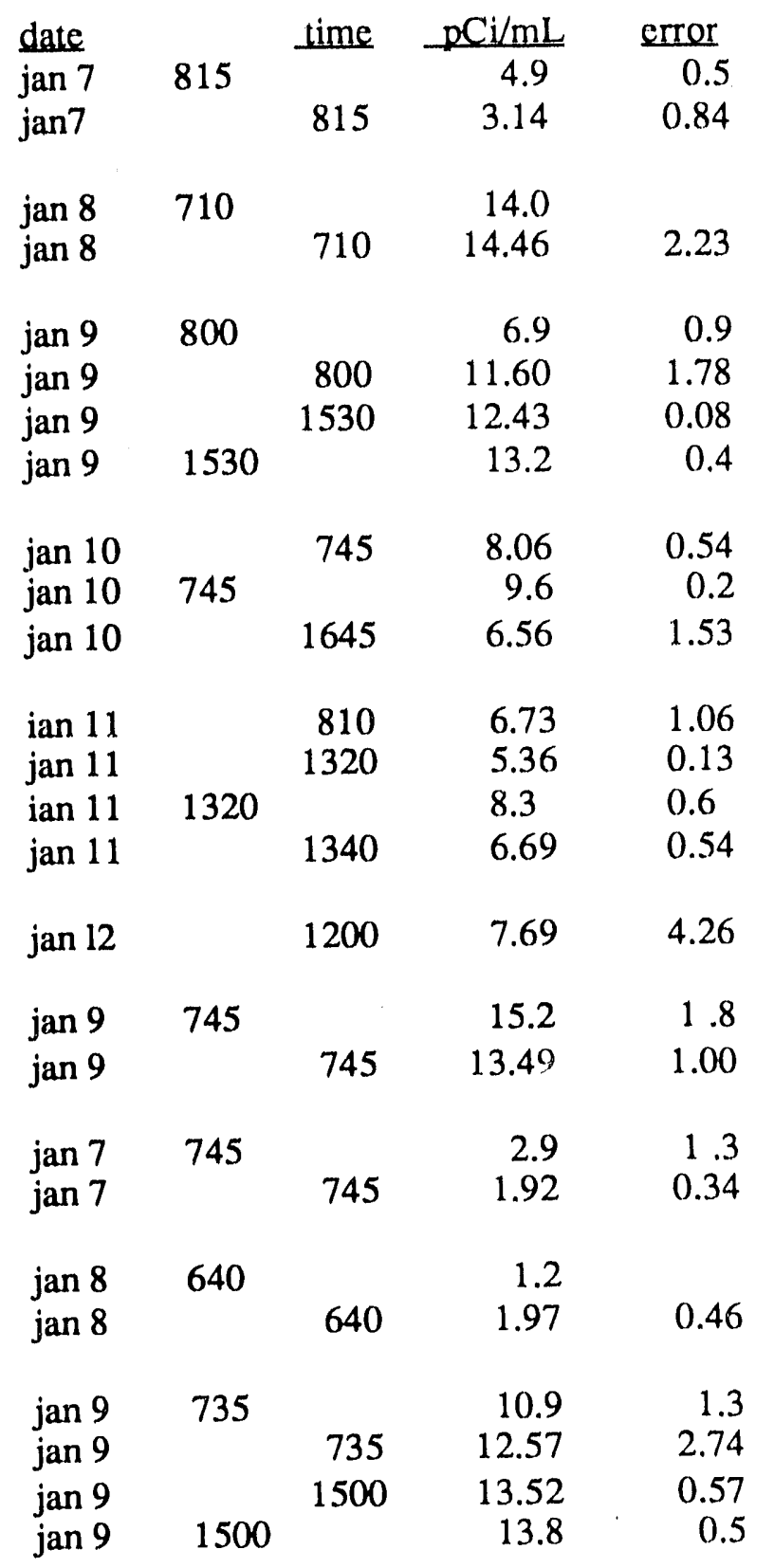


Table B6. Beaufort-Jasper canal survey after lift station (Page 2 of 5)

\begin{tabular}{|c|c|c|c|c|c|}
\hline location & date & & time & $\mathrm{DCi} / \mathrm{mL}$ & error \\
\hline \multirow[t]{10}{*}{ Highway 17 crossing (cont) } & $\operatorname{jan} 10$ & & 800 & 2.20 & 1.91 \\
\hline & jan 10 & 800 & & 13.6 & 1.1 \\
\hline & jan 10 & & 1700 & 11.18 & 1.20 \\
\hline & jan 11 & & 840 & 7.34 & 1.78 \\
\hline & jan 11 & & 1348 & 8.56 & 2.33 \\
\hline & jan 12 & & 1215 & 6.09 & 0.59 \\
\hline & $\operatorname{ian} 12$ & & 1225 & 5.96 & 0.53 \\
\hline & $\operatorname{ian} 12$ & 1225 & & 6.1 & \\
\hline & jan 14 & & 1320 & 3.77 & 0.69 \\
\hline & jan 14 & 1320 & & 2.6 & \\
\hline \multirow{4}{*}{$\begin{array}{c}2 \text { miles before Hwy } 278 \\
\text { (Jasper Rd.) }\end{array}$} & jan 12 & 1245 & & 12.1 & 1.8 \\
\hline & jan 12 & & 1245 & 13.44 & 0.18 \\
\hline & jan 14 & & 1400 & 6.12 & \\
\hline & jan 14 & 1400 & & 4.5 & \\
\hline \multirow[t]{13}{*}{ Highway 278 crossing } & jan 7 & 730 & & 3.7 & 0.5 \\
\hline & $\operatorname{jan} 7$ & & 730 & 2.28 & 1.15 \\
\hline & jan 8 & & 615 & 1.42 & \\
\hline & jan 9 & & 625 & 2.27 & 0.92 \\
\hline & $\operatorname{jan} 9$ & & 1425 & 2.79 & 1.39 \\
\hline & jan 9 & 1425 & & 2.8 & 0.2 \\
\hline & jan 10 & & 830 & 13.68 & 0.37 \\
\hline & jan 10 & & 1130 & 2.69 & 1.37 \\
\hline & jan 10 & 1130 & & 2.2 & 0.9 \\
\hline & jan 10 & & 1300 & 2.74 & 1.77 \\
\hline & jan 10 & 1300 & & 2.1 & 0.2 \\
\hline & jan 10 & & 1730 & 3.55 & 0.25 \\
\hline & $\operatorname{ian} 10$ & 1730 & & 1.4 & 0.6 \\
\hline
\end{tabular}


Table B6. Beaufort-Jasper canal survey after lift station (Page 3 of 5)

location

Highway 278 crossing (cont)

\begin{tabular}{|c|c|c|c|}
\hline date & & time & $\mathrm{pCi} / \mathrm{mL}$ \\
\hline jan 11 & 915 & & 1.7 \\
\hline jan 11 & & 915 & 1.71 \\
\hline jan 11 & & 1445 & 2.30 \\
\hline jan 11 & 1445 & & 1.9 \\
\hline jan 11 & & 1735 & 1.95 \\
\hline jan 11 & 1735 & & 3.8 \\
\hline jan 12 & & 600 & 9.83 \\
\hline jan 12 & & 740 & 2.81 \\
\hline jan 12 & 740 & & 3.1 \\
\hline jan 12 & & 1100 & 4.93 \\
\hline jan 12 & 1100 & & 4.6 \\
\hline jan 12 & & 1300 & 5.69 \\
\hline jan 12 & 1300 & & 5.0 \\
\hline jan 12 & 1800 & & 6.8 \\
\hline
\end{tabular}

$\begin{array}{llll}\text { jan } 13 & 730 & 13.49 & 0.85\end{array}$

jan $13 \quad 730$

jan 13

jan $13 \quad 1328$

jan 13

jan $13 \quad 1730$

15.2

$1328 \quad 10.70$

7.1

$1730 \quad 12.58$

6.9

jan 14

ian $14 \quad 705$

705

8.55

6.5

jan 14

jan 14

jan 14

jan $14 \quad 1700$

1145

7.34

6.7

7.21

4.3

jan 15

jan 15

jan 15
1700$$
700
$$

700

700

1000
5.69

4.5

5.54
0.08

.15
0.12

0.6

.73

0.6

2.29

0.2

0.41

0.13

0.01

1.28 
Table B6. Beaufort-Jasper canal survey after lift station (Page 4 of 5)

location

Pond Entrance

\begin{tabular}{|c|c|c|c|c|}
\hline$\frac{\text { date }}{\text { jan } 13}$ & 800 & time & $\frac{\mathrm{pCi} / \mathrm{mL}}{3.7}$ & error \\
\hline jan 13 & & 825 & 2.08 & 0.92 \\
\hline ian 13 & & 830 & & 3.48 \\
\hline jan 13 & 1340 & & nd & \\
\hline jan 13 & & 1340 & 3.07 & 0.18 \\
\hline jan 13 & & 1745 & 2.05 & 0.70 \\
\hline jan 13 & 1745 & & nd & \\
\hline jan 14 & & 715 & 9.47 & 1.30 \\
\hline n 14 & 715 & & 7.4 & \\
\hline $\ln 14$ & & 12.00 & 9.88 & 0.08 \\
\hline $\ln 14$ & 1200 & & 7.9 & \\
\hline $\mathrm{n} 1$ & & 1715 & 5.43 & 0.36 \\
\hline n 14 & 1715 & & 3.8 & \\
\hline
\end{tabular}

jan $15 \quad 710 \quad 8.86$

jan $15 \quad 710 \quad 7.3$

jan $15 \quad 1015 \quad 6.93$

jan $15 \quad 1150 \quad 9.91$

jan $15 \quad 1150 \quad 5.4$ 
Table B6. Beaufort-Jasper canal survey after lift station (Page 5 of 5)

location

Pond Exit

\begin{tabular}{lllrl} 
date & & time & pCi/mL & error \\
\cline { 5 - 5 } jan 13 & 830 & & 2.6 & \\
jan 13 & 1345 & & nd & \\
jan 13 & & 1345 & 4.02 & \\
jan 13 & & 1750 & 1.06 & 0.01 \\
jan 13 & 1750 & & nd & \\
& & & & \\
jan 14 & & 720 & 2.08 & 0.50 \\
jan 14 & 720 & & 2.4 & \\
jan 14 & & 1200 & 5.28 & 0.25 \\
jan 14 & 1200 & & 5.6 & \\
jan 14 & & 1720 & 4.56 & \\
jan 14 & 1720 & & 3.3 & \\
& & & & \\
jan 15 & & 710 & 5.69 & 0.83 \\
ian 15 & 710 & & 5.3 & \\
jan 15 & & 1019 & 5.81 & 0.56 \\
jan 15 & 1019 & & 5.2 & \\
jan 15 & 1150 & & 4.5 & \\
jan 15 & & 1155 & 6.64 &
\end{tabular}


Table B7. Beaufort-Jasper plant intake survey (Page 1 of 3)

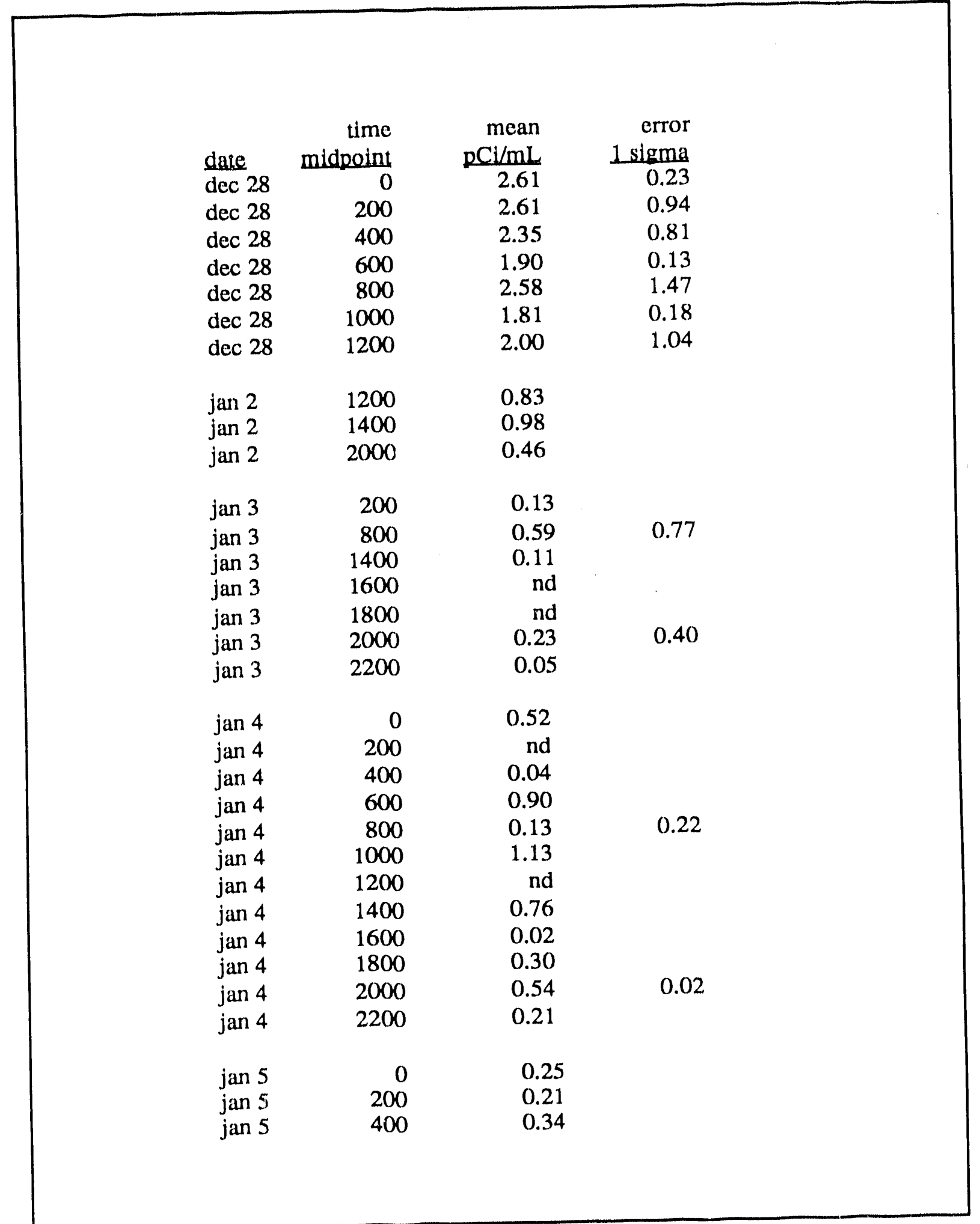


Table B7. Beaufort-Jasper plant intake survey (Page 2 of 3)

\begin{tabular}{|c|c|c|c|}
\hline date & $\begin{array}{r}\text { time } \\
\text { midpoint }\end{array}$ & $\begin{array}{c}\text { mean } \\
\mathrm{pCi} / \mathrm{mL}\end{array}$ & $\begin{array}{r}\text { error } \\
1 \text { sigma }\end{array}$ \\
\hline jan 5 & 600 & 0.42 & 0.42 \\
\hline jan 5 & 800 & nd & \\
\hline jan 5 & 1000 & 0.73 & \\
\hline jan 5 & 1200 & 0.69 & \\
\hline jan 5 & 1400 & 0.04 & \\
\hline jan 5 & 1800 & 0.45 & 0.40 \\
\hline jan 5 & 2000 & 0.17 & 0.17 \\
\hline jan 5 & 2200 & 0.15 & 0.11 \\
\hline jan 6 & 0 & 0.13 & 0.13 \\
\hline jan 6 & 200 & 1.43 & 0.79 \\
\hline jan 6 & 600 & 0.33 & 0.57 \\
\hline jan 6 & 800 & 0.64 & 0.28 \\
\hline jan 6 & 1000 & 0.47 & 0.47 \\
\hline jan 6 & 1200 & 0.17 & 0.17 \\
\hline an 6 & 1400 & 0.38 & 0.37 \\
\hline jan 6 & 1600 & 0.33 & 0.43 \\
\hline jan 6 & 1800 & nd & nd \\
\hline jan 6 & 2000 & 0.25 & 0.42 \\
\hline jan 6 & 2200 & nd & \\
\hline jan 7 & 0 & nd & nd \\
\hline jan 7 & 200 & 0.34 & 0.46 \\
\hline jan 7 & 400 & 0.57 & 0.78 \\
\hline $\operatorname{jan} 7$ & 600 & nd & nd \\
\hline jan 7 & 800 & 0.48 & 0.24 \\
\hline jan 7 & 1000 & 1.18 & 1.64 \\
\hline jan 7 & 1200 & 0.89 & 1.02 \\
\hline jan 7 & 1400 & 0.37 & 0.39 \\
\hline jan 7 & 2000 & 1.35 & 2.25 \\
\hline jan 8 & 400 & 0.20 & 0.28 \\
\hline jan 8 & 1200 & 0.14 & 0.24 \\
\hline jan 8 & 1600 & 1.55 & 1.31 \\
\hline
\end{tabular}


Table B7. Beaufort-Jasper plant intake survey (Page 3 of 3 )

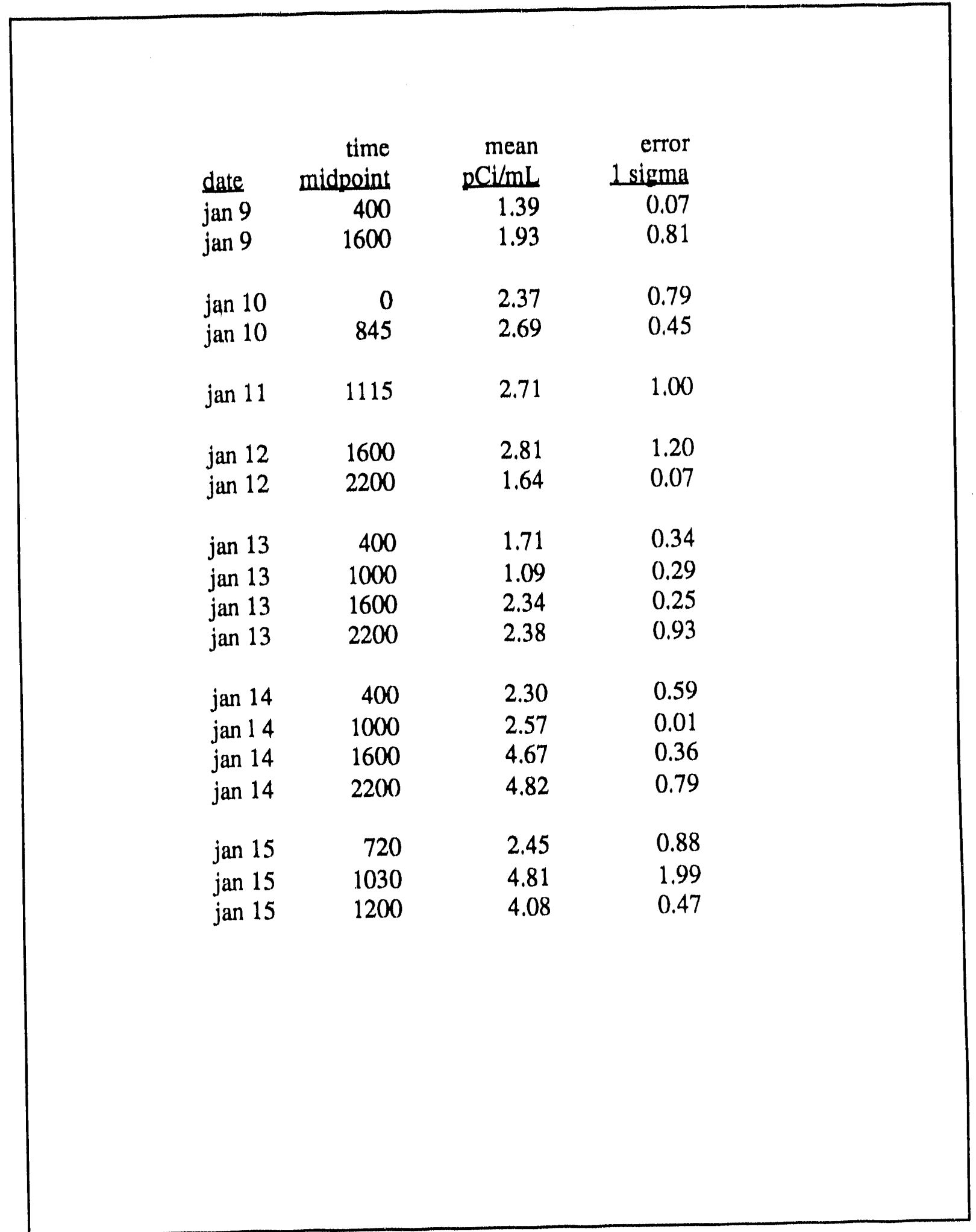


Table B8. Beaufort-Jasper water treatment plant survey (Page 1 of 2)

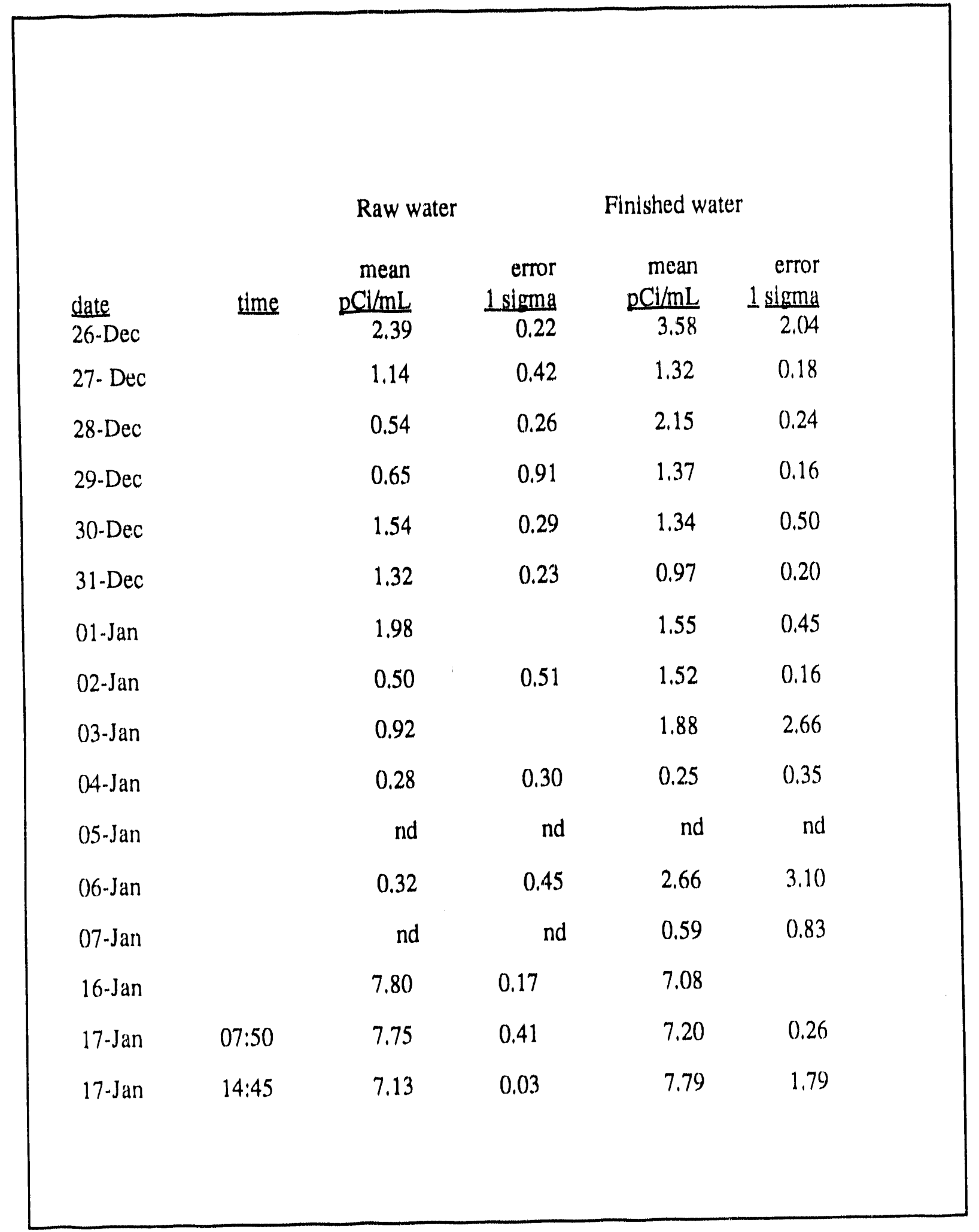


Table B8. Beaufort-Jasper water treatment plant survoy (Page 2 of 2)

\begin{tabular}{|c|c|c|c|c|c|}
\hline & & Raw H & \multicolumn{3}{|c|}{ Finished Water } \\
\hline date & time & mean & error & mean & error \\
\hline 18.Jan & $00: 30$ & 7.46 & 0.08 & 5.57 & 0.37 \\
\hline 18-Jan & $08: 30$ & 6.10 & 0.51 & 6.46 & 0.85 \\
\hline 19-Jan & $00: 01$ & 5.72 & 0.42 & 5.02 & 0.71 \\
\hline 19.Jan & $08: 30$ & 4.23 & 5.06 & 0.70 & \\
\hline 20-Jan & $07: 30$ & 3.45 & 3.95 & 0.40 & \\
\hline 21-Jan & $07: 40$ & 4.28 & 0.70 & 4.93 & 0.42 \\
\hline 22-Jan & $07: 45$ & 4.87 & 0.39 & 4.59 & 0.38 \\
\hline 22-Jan & $21: 00$ & 4.68 & 0.27 & 4.63 & 0.49 \\
\hline 23-Jan & $08: 00$ & 3.99 & 1.26 & 5.03 & 0.75 \\
\hline 24-Jan & $08: 10$ & 3.91 & 1.03 & 4.17 & 0.22 \\
\hline 25-Jan & $07: 25$ & 4.13 & 0.21 & 3.82 & 0.26 \\
\hline 26-Jan & $07: 45$ & 3.91 & 0.41 & 3.69 & 0.64 \\
\hline 27-Jan & $07: 30$ & 3.34 & 0.14 & 3.45 & 0.82 \\
\hline
\end{tabular}


Table 139. Abercorn Creck Survoy (Page 1 of 9)

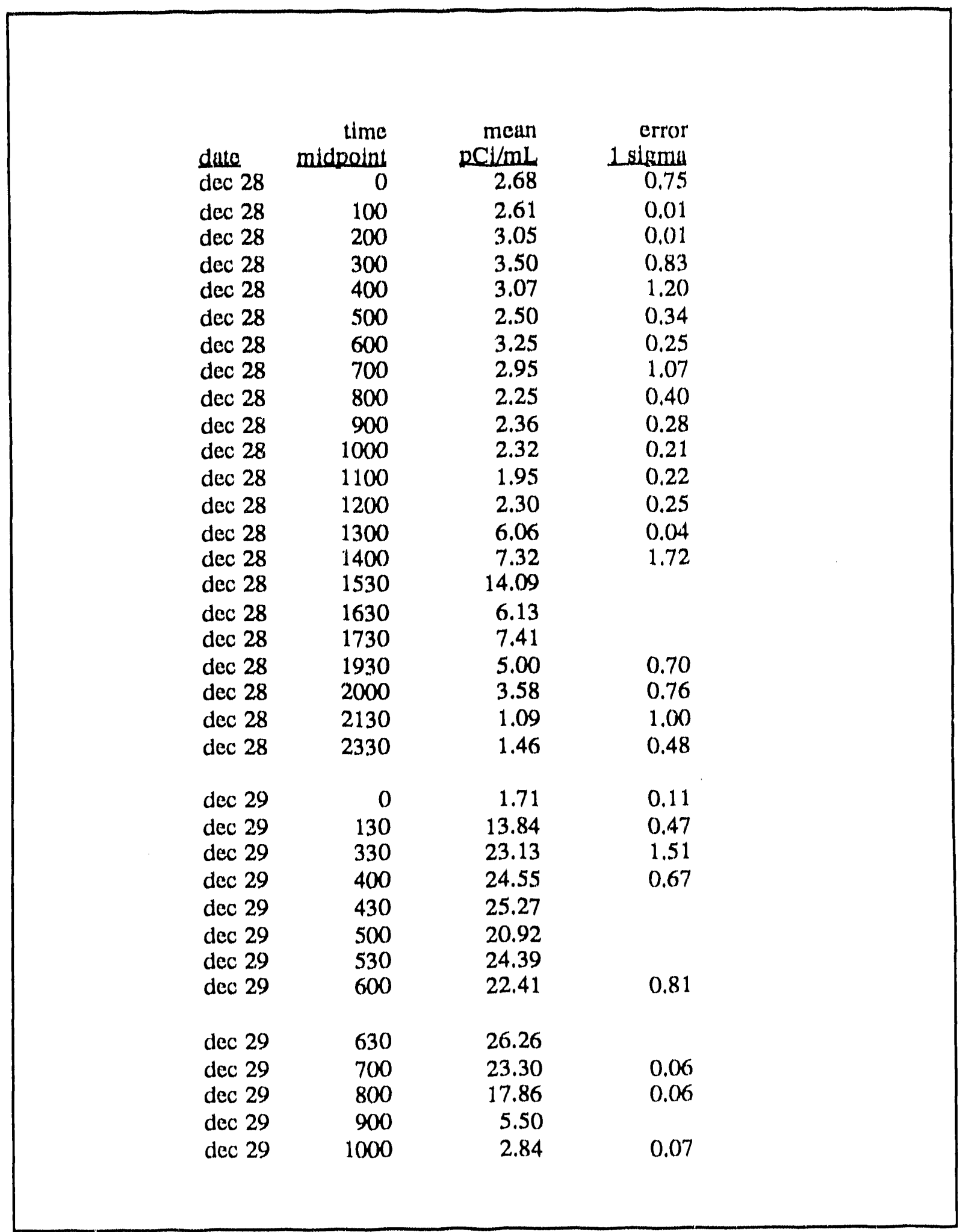


Table B9. Abercorn Creek Survey (Page 2 of 9)

\begin{tabular}{|c|c|c|c|}
\hline date & $\begin{array}{r}\text { time } \\
\text { midpoint }\end{array}$ & $\begin{array}{r}\text { mean } \\
\mathrm{pCi} / \mathrm{mL}\end{array}$ & $\begin{array}{r}\text { error } \\
1 \text { sigma }\end{array}$ \\
\hline $\operatorname{dec} 29$ & 1030 & 1.59 & \\
\hline $\operatorname{dec} 29$ & 1130 & 1.26 & \\
\hline $\operatorname{dec} 29$ & 1230 & 1.80 & \\
\hline $\operatorname{dec} 29$ & 1330 & 1.42 & \\
\hline $\operatorname{dec} 29$ & 1430 & 35.30 & \\
\hline $\operatorname{dec} 29$ & 1530 & 40.26 & \\
\hline $\operatorname{dec} 29$ & 1630 & 43.25 & \\
\hline $\operatorname{dec} 29$ & 1730 & 44.92 & \\
\hline $\operatorname{dec} 29$ & 1830 & 41.15 & \\
\hline $\operatorname{dec} 29$ & 1900 & 32.90 & \\
\hline $\operatorname{dec} 29$ & 1930 & 18.28 & \\
\hline $\operatorname{dec} 29$ & 2000 & 9.58 & \\
\hline $\operatorname{dec} 29$ & 2300 & 2.77 & 0.39 \\
\hline $\operatorname{dec} 30$ & $\begin{array}{r}0 \\
100\end{array}$ & $\begin{array}{l}1.98 \\
1.56\end{array}$ & \\
\hline $\operatorname{dec} 30$ & $\begin{array}{l}100 \\
200\end{array}$ & $\begin{array}{l}1.56 \\
6.74\end{array}$ & \\
\hline $\operatorname{dec} 30$ & $\begin{array}{l}200 \\
400\end{array}$ & $\begin{array}{r}6.74 \\
50.34\end{array}$ & \\
\hline $\operatorname{dec} 30$ & $\begin{array}{l}400 \\
600\end{array}$ & $\begin{array}{l}51.25 \\
51.25\end{array}$ & \\
\hline $\operatorname{dec} 30$ & 600 & 31.25 & 2.54 \\
\hline $\operatorname{dec} 30$ & 800 & 49.04 & \\
\hline $\operatorname{dec} 30$ & 1000 & 7.20 & \\
\hline $\operatorname{dec} 30$ & 1000 & 8.70 & \\
\hline $\operatorname{dec} 30$ & 1030 & 4.03 & \\
\hline $\operatorname{dec} 3 c$ & 1230 & 2.81 & \\
\hline $\operatorname{dec} 30$ & 1330 & 2.81 & 2.41 \\
\hline $\operatorname{dec} 30$ & $1: 30$ & 6.20 & \\
\hline $\operatorname{dec} 30$ & 1430 & 10.68 & \\
\hline $\operatorname{dec} 30$ & 1430 & 11.80 & \\
\hline $\operatorname{dec} 30$ & 1530 & 49.59 & \\
\hline $\operatorname{dec} 30$ & 1630 & 49.14 & \\
\hline $\operatorname{dec} 30$ & 1730 & 52.73 & \\
\hline $\operatorname{dec} 30$ & 1900 & 44.94 & \\
\hline $\operatorname{dec} 30$ & 1930 & 27.60 & \\
\hline $\operatorname{dec} 30$ & 2030 & 29.16 & \\
\hline $\operatorname{dec} 30$ & 2100 & 16.89 & \\
\hline $\operatorname{dec} 30$ & 2200 & 6.40 & 2.12 \\
\hline $\operatorname{dec} 30$ & 2300 & 3.28 & \\
\hline
\end{tabular}


Table B9. Abercorn Creek Survey (Page 3 of 9)

\begin{tabular}{|c|c|c|c|}
\hline date & $\begin{array}{r}\text { time } \\
\text { midpoint }\end{array}$ & $\begin{array}{c}\text { mean } \\
\mathrm{pCi} / \mathrm{mL}\end{array}$ & $\begin{array}{r}\text { error } \\
1 \text { sigma }\end{array}$ \\
\hline $\operatorname{dec} 31$ & 000 & 5.47 & \\
\hline $\begin{array}{l}\operatorname{dec} 31 \\
\operatorname{dec} 31 \\
\operatorname{dec} 31\end{array}$ & $\begin{array}{l}100 \\
200 \\
230\end{array}$ & $\begin{array}{l}5.01 \\
3.44 \\
7.22\end{array}$ & 0.51 \\
\hline $\begin{array}{l}\operatorname{dec} 31 \\
\operatorname{dec} 31\end{array}$ & $\begin{array}{l}300 \\
400\end{array}$ & $\begin{array}{l}28.77 \\
42.50\end{array}$ & 2.93 \\
\hline $\begin{array}{l}\operatorname{dec} 31 \\
\operatorname{dec} 31\end{array}$ & $\begin{array}{ll}400 & \\
& \\
500\end{array}$ & 43.30 & \\
\hline $\begin{array}{l}\operatorname{dec} 31 \\
\operatorname{dec} 31\end{array}$ & $500^{500}$ & $\begin{array}{l}49.56 \\
39.70\end{array}$ & 0.37 \\
\hline $\operatorname{dec} 31$ & 600 & 45.79 & .1 .75 \\
\hline $\operatorname{dec} 31$ & 600 & 40.50 & \\
\hline $\operatorname{dec} 31$ & 700 & 39.19 & 8.67 \\
\hline $\operatorname{dec} 31$ & 700 & 41.30 & \\
\hline $\operatorname{dec} 31$ & 800 & 45.97 & \\
\hline $\operatorname{dec} 31$ & 900 & 50.12 & 4.19 \\
\hline $\operatorname{dec} 31$ & 1000 & 44.59 & \\
\hline $\operatorname{dec} 31$ & 1100 & 31.55 & \\
\hline $\operatorname{dec} 31$ & 1200 & 13.59 & 0.88 \\
\hline $\operatorname{dec} 31$ & 1300 & 8.51 & \\
\hline $\operatorname{dec} 31$ & 1400 & 8.42 & \\
\hline $\operatorname{dec} 31$ & 1500 & 18.31 & \\
\hline $\operatorname{dec} 31$ & 1530 & 31.74 & 1.32 \\
\hline $\operatorname{dec} 31$ & 1600 & 38.40 & \\
\hline $\operatorname{dec} 31$ & 1700 & 43.93 & \\
\hline $\operatorname{dec} 31$ & 1800 & 47.15 & 0.18 \\
\hline $\operatorname{dec} 31$ & 1900 & 48.55 & \\
\hline $\operatorname{dec} 31$ & 2000 & 43.46 & \\
\hline $\operatorname{dec} 31$ & 2100 & 42.56 & \\
\hline $\operatorname{dec} 31$ & 2200 & 23.33 & \\
\hline $\operatorname{dec} 31$ & 2200 & 26.80 & \\
\hline $\operatorname{dec} 31$ & 2300 & 12.02 & \\
\hline $\operatorname{dec} 31$ & 2300 & 13.30 & \\
\hline jan 1 & 0 & 8.30 & \\
\hline jan 1 & 100 & 12.33 & \\
\hline jan 1 & 200 & 11.36 & \\
\hline
\end{tabular}


Table B9. Abercorn Creek Survey (Page 4 of 9)

\begin{tabular}{|c|c|c|c|}
\hline date & $\begin{array}{r}\text { time } \\
\text { midpoint }\end{array}$ & $\begin{array}{c}\text { mean } \\
\mathrm{DC} \mathrm{C} / \mathrm{mL}\end{array}$ & $\begin{array}{r}\text { error } \\
1 \text { sigma } \\
\end{array}$ \\
\hline $\begin{array}{l}\text { jan } 1 \\
\text { jan } 1\end{array}$ & $\begin{array}{l}300 \\
400\end{array}$ & $\begin{array}{l}19.90 \\
38.34\end{array}$ & \\
\hline jan 1 & 600 & 39.49 & \\
\hline jan 1 & 700 & 36.93 & \\
\hline jan 1 & 800 & 38.46 & \\
\hline jan 1 & $\begin{array}{l}1000 \\
1200\end{array}$ & $\begin{array}{l}39.24 \\
34.88\end{array}$ & 187 \\
\hline $\operatorname{jan} 1$ & 1400 & $\begin{array}{l}34.80 \\
14.29\end{array}$ & 0.06 \\
\hline $\begin{array}{l}\operatorname{jan} 1 \\
\operatorname{jan} 1\end{array}$ & 1500 & $\begin{array}{l}14.27 \\
15.60\end{array}$ & \\
\hline $\begin{array}{l}\text { jan } 1 \\
\text { jan } 1\end{array}$ & 1600 & 18.79 & \\
\hline & 1700 & 32.46 & \\
\hline jan l & 1800 & 30.11 & 0.01 \\
\hline jan! & 1000 & 34.10 & \\
\hline jan 1 & 1900 & 34.10 & \\
\hline jan 1 & 2200 & 34.44 & \\
\hline jan 2 & 100 & 19.09 & \\
\hline jan 2 & 400 & 15.61 & 1.97 \\
\hline jan 2 & 400 & 15.70 & \\
\hline $\operatorname{jan} 2$ & 445 & 21.31 & \\
\hline jan 2 & 445 & 29.10 & \\
\hline jan 2 & 500 & 29.85 & \\
\hline jan 2 & 700 & 31.25 & 2.45 \\
\hline jan 2 & 900 & 34.38 & \\
\hline jan 2 & 1000 & 28.55 & \\
\hline $\mathrm{jan} 2$ & 1100 & 31.74 & \\
\hline $\begin{array}{l}\mathrm{jan} 2 \\
\mathrm{jan} 2\end{array}$ & $\begin{array}{l}1300 \\
1330\end{array}$ & $\begin{array}{l}29.87 \\
22.11\end{array}$ & 1.31 \\
\hline jan 2 & 1500 & 21.67 & \\
\hline jan 2 & 1600 & 22.18 & \\
\hline jan 2 & 1700 & 23.90 & \\
\hline jan 2 & 1900 & 26.64 & \\
\hline jan 2 & 1900 & 23.54 & 1.34 \\
\hline jan 2 & 2000 & 26.02 & \\
\hline jan 2 & 2200 & 24.82 & \\
\hline jan 2 & 2300 & 23.29 & \\
\hline
\end{tabular}


Table B9. Abercorn Creek Survey (Page 5 of 9)

\begin{tabular}{|c|c|c|c|}
\hline date & $\begin{array}{r}\text { time } \\
\text { midpoint }\end{array}$ & $\begin{array}{r}\text { mean } \\
\mathrm{pCi} / \mathrm{mL}\end{array}$ & $\begin{array}{r}\text { error } \\
1 \text { sigma }\end{array}$ \\
\hline jan 3 & 100 & 26.22 & \\
\hline jan 3 & 200 & 24.20 & \\
\hline jan 3 & 400 & 25.35 & \\
\hline jan 3 & 445 & 25.96 & \\
\hline jan 3 & 600 & 19.53 & \\
\hline jan 3 & 800 & 20.45 & \\
\hline jan 3 & 1000 & 19.11 & 0.85 \\
\hline jan 3 & 1200 & 19.17 & 3.45 \\
\hline jan 3 & 1300 & 19.13 & \\
\hline jan 3 & 1400 & 20.32 & \\
\hline jan 3 & 1500 & 24.01 & \\
\hline jan 3 & 1600 & 23.64 & 3.46 \\
\hline jan 3 & 1700 & 24.99 & \\
\hline jan 3 & 1800 & 20.70 & \\
\hline jan 3 & 1900 & 19.06 & \\
\hline jan 3 & 2000 & 14.76 & 2.11 \\
\hline jan 3 & 2100 & 13.59 & \\
\hline jan 3 & 2200 & 15.00 & \\
\hline jan 3 & 2300 & 15.44 & \\
\hline jan 4 & 0 & 18.35 & \\
\hline jan 4 & 100 & 20.94 & \\
\hline jan 4 & 200 & 23.62 & \\
\hline jan 4 & 300 & 23.65 & \\
\hline jan 4 & 400 & 22.73 & \\
\hline jan 4 & 500 & 23.53 & \\
\hline $\operatorname{jan} 4$ & 600 & 9.84 & 5.39 \\
\hline jan 4 & 700 & 6.09 & 0.92 \\
\hline jan 4 & 800 & 11.00 & \\
\hline jan 4 & 800 & 11.26 & 1.22 \\
\hline jan 4 & 900 & 11.90 & \\
\hline jan 4 & 1000 & 12.67 & \\
\hline jan 4 & 1100 & $\begin{array}{r}12.40 \\
9.58\end{array}$ & 0.40 \\
\hline $\operatorname{an} 4$ & $\begin{array}{l}1200 \\
1300\end{array}$ & $\begin{array}{r}9.58 \\
12.36\end{array}$ & 0.40 \\
\hline $\begin{array}{l}\operatorname{jan} 4 \\
\operatorname{jan} 4\end{array}$ & $\begin{array}{l}1300 \\
1400\end{array}$ & 15.04 & \\
\hline jan 4 & & & \\
\hline
\end{tabular}


Table B9. Abercorn Creek Survey (Page 6 of 9)

\begin{tabular}{|c|c|c|c|}
\hline date & $\begin{array}{r}\text { time } \\
\text { midpoint }\end{array}$ & $\begin{array}{c}\text { mean } \\
\mathrm{pCi} / \mathrm{mL}\end{array}$ & $\begin{array}{r}\text { error } \\
1 \text { sigma }\end{array}$ \\
\hline jan 4 & 1500 & 19.30 & 0.86 \\
\hline jan 4 & 1500 & 21.40 & \\
\hline jan 4 & 1600 & 18.61 & 3.67 \\
\hline jan 4 & 1700 & 18.14 & \\
\hline jan 4 & 1800 & 15.42 & 5.28 \\
\hline jan 4 & 1900 & 21.12 & \\
\hline jan 4 & 2000 & 8.34 & \\
\hline jan 4 & 2100 & 8.16 & 0.25 \\
\hline jan 4 & 2200 & 9.05 & \\
\hline jan 4 & 2300 & 7.39 & \\
\hline jan 5 & 0 & 7.41 & \\
\hline jan 5 & 100 & 11.44 & \\
\hline jan 5 & 200 & 17.47 & 0.78 \\
\hline jan 5 & 300 & 16.87 & \\
\hline jan 5 & 400 & 10.00 & 0.54 \\
\hline jan 5 & 500 & 20.10 & \\
\hline jan 5 & 500 & 20.69 & \\
\hline jan 5 & 600 & 16.43 & 0.66 \\
\hline jan 5 & 700 & 17.40 & \\
\hline jan 5 & 700 & 16.50 & \\
\hline jan 5 & 800 & 17.21 & \\
\hline jan 5 & 900 & 8.40 & \\
\hline jan 5 & 900 & 7.88 & \\
\hline jan 5 & 1000 & 9.31 & \\
\hline jan 5 & 1100 & 7.69 & 0.51 \\
\hline jan 5 & 1200 & 6.14 & \\
\hline jan 5 & 1300 & 7.09 & \\
\hline $\operatorname{jan} 5$ & 1400 & 8.58 & \\
\hline jan 5 & 1600 & 17.58 & \\
\hline jan 5 & 1800 & 16.79 & \\
\hline jan 5 & 2000 & 8.66 & 0.34 \\
\hline jan5 & 2200 & 6.17 & \\
\hline jan 6 & 0 & 6.48 & \\
\hline jan 6 & 200 & 10.40 & 0.23 \\
\hline jan 6 & 300 & 17.00 & 2.36 \\
\hline
\end{tabular}


Table B9. Abercorn Creek Survey (Page 7 of 9)

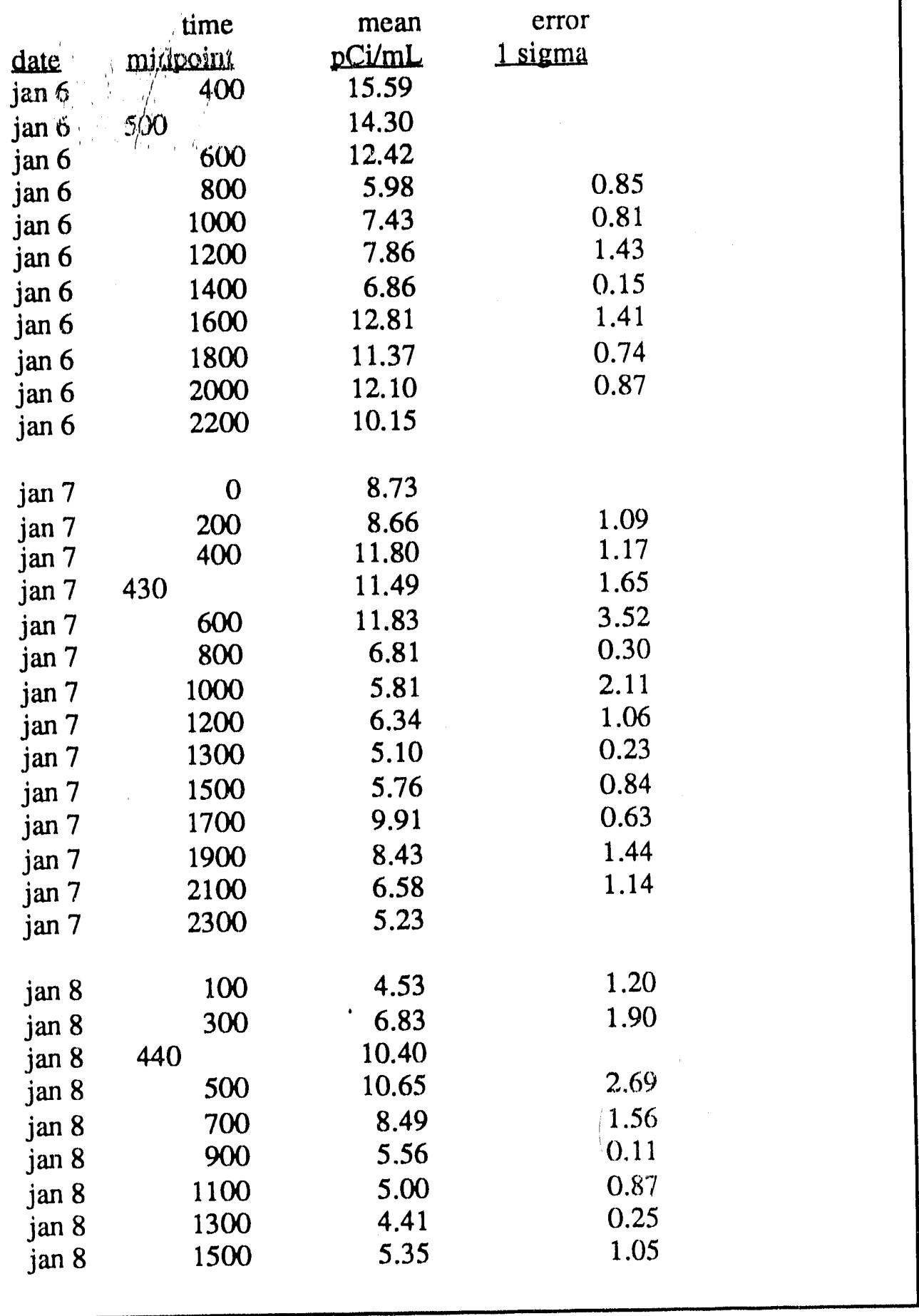


Table B9. Abcrcom Creek Survey (Page 8 of 9)

\begin{tabular}{|c|c|c|c|}
\hline date & $\begin{array}{r}\text { time } \\
\text { midpoint }\end{array}$ & $\begin{array}{c}\text { mean } \\
\mathrm{pCi} / \mathrm{mL}\end{array}$ & $\begin{array}{r}\text { error } \\
1 \text { sigma }\end{array}$ \\
\hline $\operatorname{jan} 8$ & 1700 & 7.28 & \\
\hline jan 8 & 1900 & 8.09 & 2.33 \\
\hline jan 8 & 2100 & 9.11 & 0.95 \\
\hline jan 8 & 2300 & 3.72 & 1.84 \\
\hline jan 9 & 100 & 3.03 & 0.57 \\
\hline jan 9 & 300 & 4.59 & 1.44 \\
\hline jan 9 & 400 & 8.36 & \\
\hline jan 9 & 400 & 8.19 & 1.12 \\
\hline jan 9 & 435 & 7.99 & 1.39 \\
\hline jan 9 & 700 & 6.57 & 0.21 \\
\hline jan 9 & 900 & 6.37 & 0.79 \\
\hline jan 9 & 1100 & 4.27 & 1.27 \\
\hline jan 9 & 1500 & 4.69 & 1.20 \\
\hline jan 9 & 2100 & 7.87 & 1.62 \\
\hline jan 10 & 300 & 5.53 & 0.21 \\
\hline jan 10 & 900 & 7.14 & 2.67 \\
\hline jan 10 & 1927 & 6.09 & 2.68 \\
\hline $\operatorname{ian} 11$ & 139 & 5.09 & 0.28 \\
\hline jan 11 & 751 & 6.25 & 0.70 \\
\hline jan 11 & 1404 & 6.49 & 0.45 \\
\hline jan 11 & 2016 & 6.17 & 0.28 \\
\hline jan 12 & 18 & 5.83 & 0.42 \\
\hline jan 12 & 630 & 5.10 & 0.08 \\
\hline jan 12 & 1453 & 3.08 & 0.19 \\
\hline jan 12 & 2105 & 4.04 & 0.36 \\
\hline jan 13 & 317 & 3.72 & 0.92 \\
\hline jan 13 & 929 & 4.25 & 0.64 \\
\hline jan 13 & 1541 & 3.15 & 0.59 \\
\hline jan 13 & 1600 & 3.70 & \\
\hline jan 13 & 2135 & 1.84 & 0.57 \\
\hline
\end{tabular}


Table B9. Abercorn Creek Survey (Page 9 of 9)

$\begin{array}{lrrr}\text { date } & \begin{array}{r}\text { time } \\ \text { midpoint }\end{array} & \begin{array}{r}\text { mean } \\ \text { pCi/mL }\end{array} & \begin{array}{r}\text { error } \\ \text { 1sigma }\end{array} \\ \text { jan 14 } & 405 & 2.04 & 0.45 \\ \text { jan 14 } & 1017 & 0.47 & 0.51 \\ \text { jan 14 } & 1630 & 0.85 & 0.38 \\ \text { jan 14 } & 2242 & 0.11 & 0.14 \\ & & & \\ \text { jan 15 } & 454 & 1.97 & 0.42 \\ \text { jan 15 } & 1106 & 0.67 & 0.38\end{array}$


Table B10. Port Wentworth water treatment plant survey (Page 1 of 2)

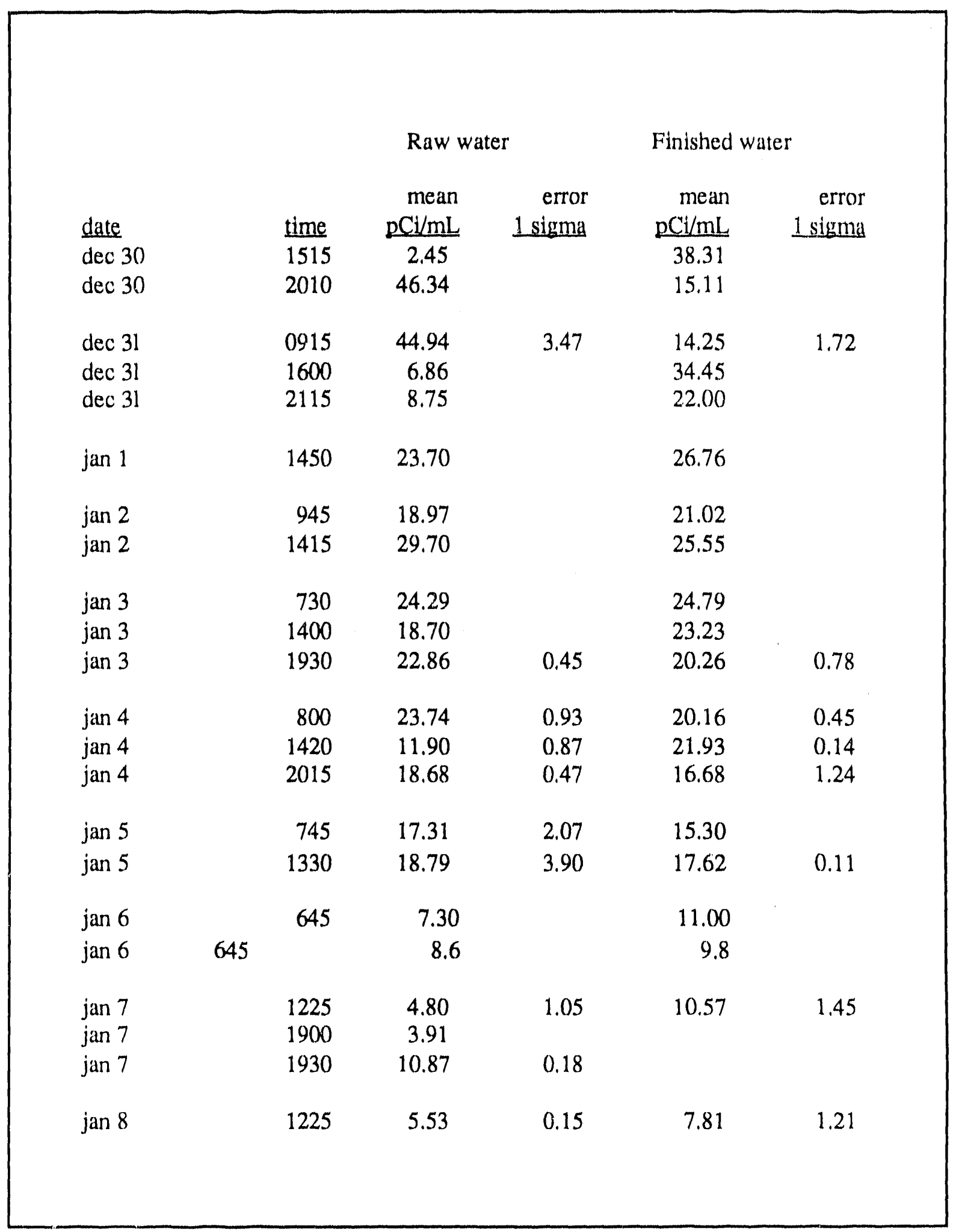


Table B10. Port Wentworth water treatment plant survey (Page 2 of 2)

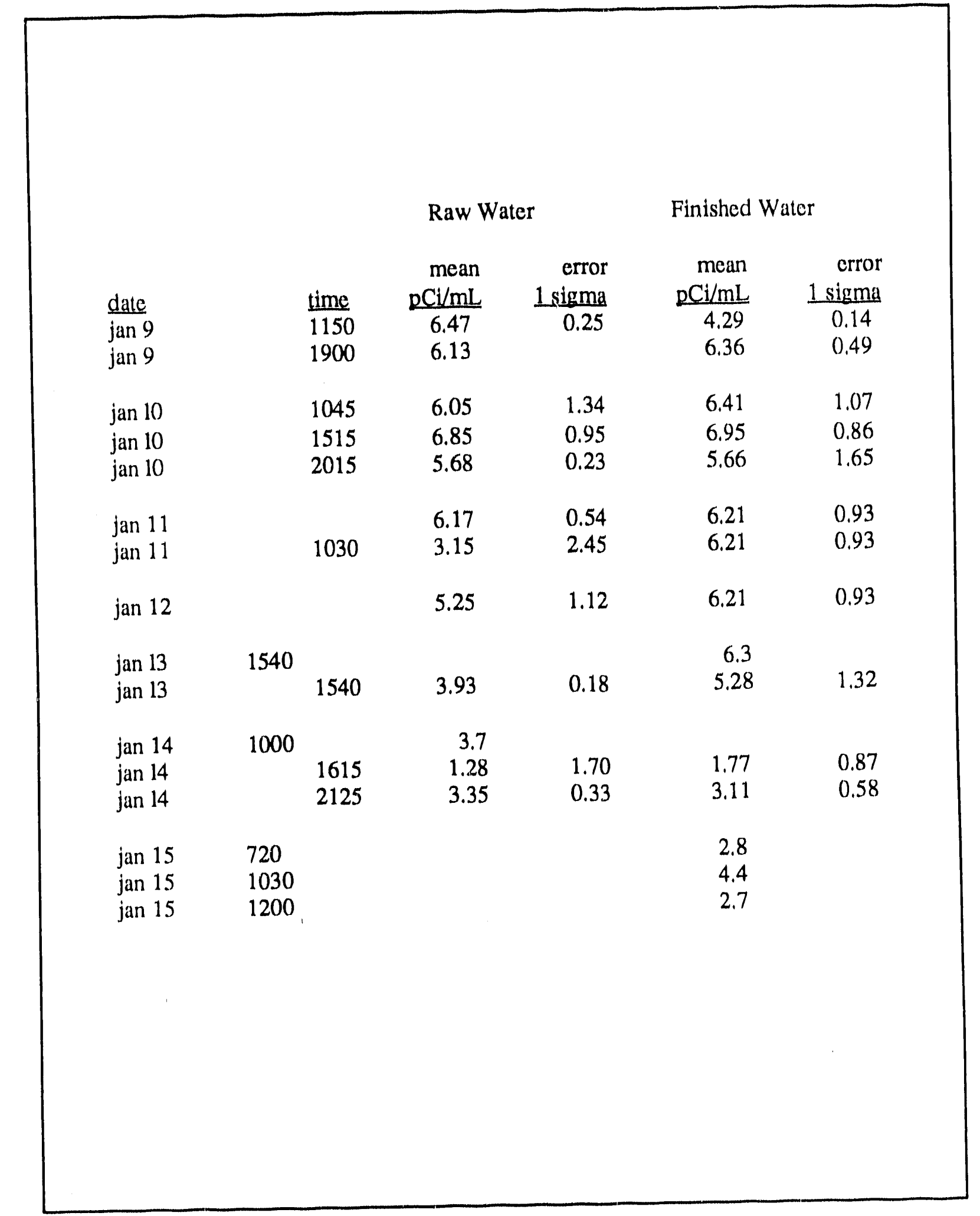


Table B11. Estuarine study (Page 1 of 6)

lecition

Fort Pulask1 date

dec 31

dec 31

Jan 1

Jan 1

jan 1

Jan 1

jan 1

jan 1

$\tan 2$

jan 2

jan 2

jan 2

jan 2

jan 2

jan 2

jan 3

jan 3

jan 3

jan 3

jan 3

jan 3

jan 3

jan 3

Jan 3

Jan 3

jan 3

jan 4

jan 4

jan 4

jan 4

jan 4

jan 4

jan 4

jan 4 time

12:30

$20: 30$

$00: 30$

04:30

08:30

$12: 30$

$16: 30$

$20: 30$

$00: 30$

04:30

08:30

$12: 30$

$14: 45$

$16: 30$

20:30

$00: 30$

04:30

08:07

08:30

10:30

$12: 30$

$14: 30$

$16: 30$

18:30

20:30

22:30

00:30

02:30

04:30

06:30

08:30

10:30

$11: 25$

$12: 30$

$\begin{array}{rr}\mathrm{DCl} / \mathrm{mL} & \begin{array}{r}\text { crror } \\ \text { Lsigma }\end{array} \\ 2.57 & 0.27 \\ 2.29 & \end{array}$

4.06

1.43

0.37

6.71

4.07

3.60

0.47

10.77

5.96

8.85

0.45

14.27

8.53

10.20

0.84

9.96

3.36

0.82

4.72

4.73

13.54

11.43

3.30

3.15

8.72

0.09

1.92

0.07

0.48

0.20

0.57

0.13

0.49

13.55

3.65

16.46

14.01

3.45

1.22

3.61

1.73

0.51

8.28

0.13

12.18

0.13 
Table B 11. Estuarinc study (Page 2 of 6 )

location

Fort Pulaski (cont)

\begin{tabular}{|c|c|}
\hline date & the \\
\hline jan 4 & $14: 30$ \\
\hline jan 4 & $16: 30$ \\
\hline jan 4 & $18: 30$ \\
\hline jan 4 & $20: 30$ \\
\hline Jan 4 & $22: 30$ \\
\hline jan 5 & $00: 30$ \\
\hline jan 5 & $02: 30$ \\
\hline jan 5 & $(04: 30$ \\
\hline jan 5 & $06: 30$ \\
\hline jan 5 & $08: 30$ \\
\hline jan 5 & $10: 30$ \\
\hline jan 5 & $12: 30$ \\
\hline jan 5 & $14: 30$ \\
\hline jan 5 & $16: 30$ \\
\hline jan 5 & $18: 30$ \\
\hline 115 & $20: 30$ \\
\hline & 2 \\
\hline
\end{tabular}

jan 6

Jan 6

jan 6

Jan 6

jan 6

jan 6

jan 6

jan 6

jan 6

jan 6

jan 7

jan 7

jan 7

jan 7

jan 7

jan 7

jan 8

jan 8

jan 8

jan 8
$02: 30$

04:30

06:30

08:30

$10: 30$

$11: 30$

11:40

$13: 30$

19:30

23:30

03:30

07:30

$11: 30$

$15: 30$

19:30

23:30

03:30

07:30

11:30

$15: 30$

\begin{tabular}{rr} 
pCV/mul & $\begin{array}{r}\text { crror } \\
\text { 1sigmo }\end{array}$ \\
\hline 15.50 & 1.25 \\
16.87 & 1.07 \\
7.40 & 0.16 \\
5.48 & 2.02 \\
7.38 & 0.51
\end{tabular}

11.34

1.5 .98

14.63

3.74

5.35

3.85

10.32

14.51

14.11

7.55

5.33

5.17

1.08

0.18

0.69

1.23

0.39

0.79

1.38

0.25

1.78

0.42

0.61

0.11

13.99

4.50

0.24

8.41

5.21

3.06

3.57

2.86

12.16

4.32

8.13

0.97

2.47

1.77

0.17

0.23

0.29

0.57

0.48

0.07

\subsection{3}

1.31

6.98

4.41

1.11

11.34

8.59

6.42

0.74

0.13

11.00

8.11

0.13

2.54

2.52

9.43 
Tuble B11. Estuarinc studly (Page 3 of 6 )

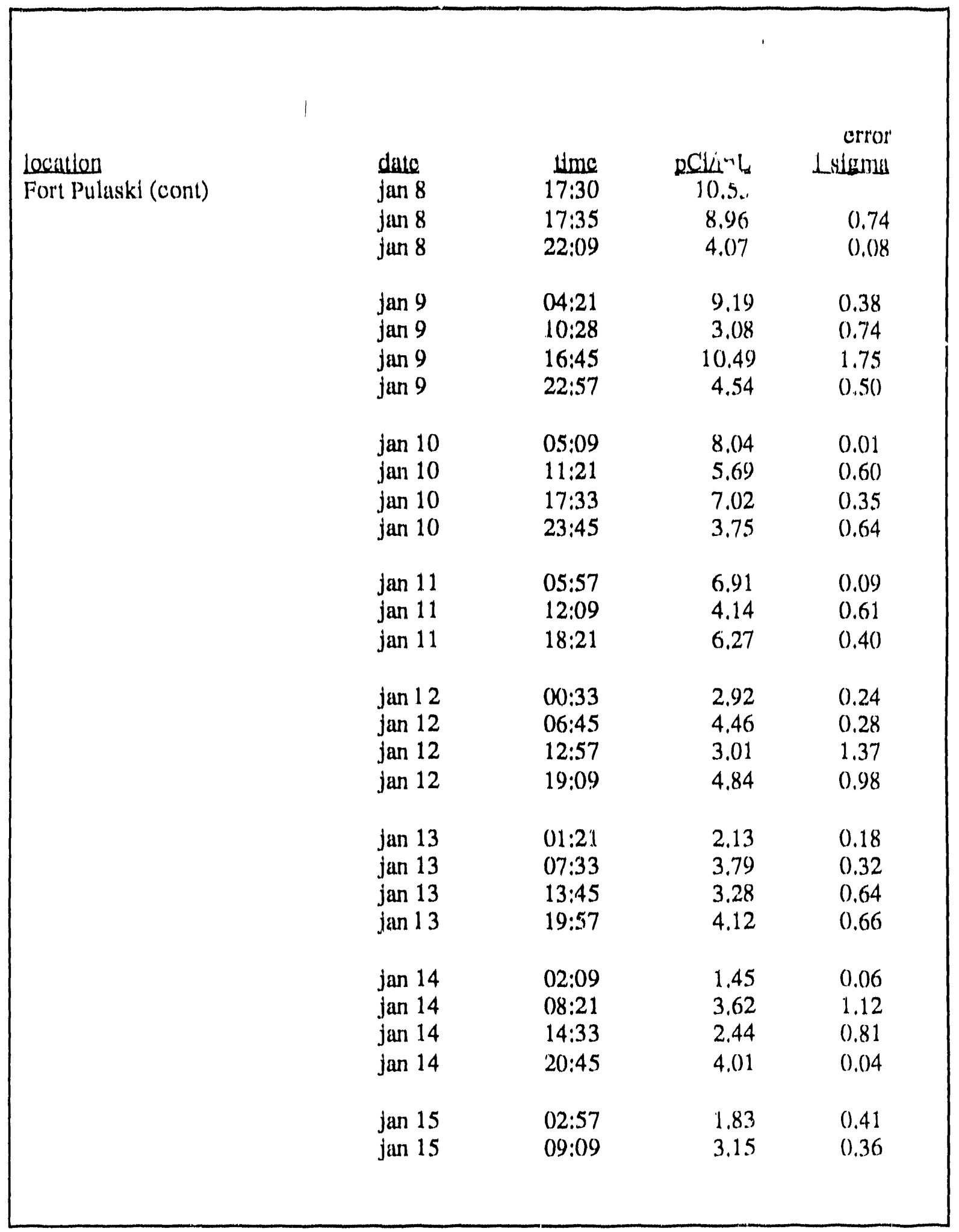


I'able 1311. Estuarine study (Pago 4 of 6 )

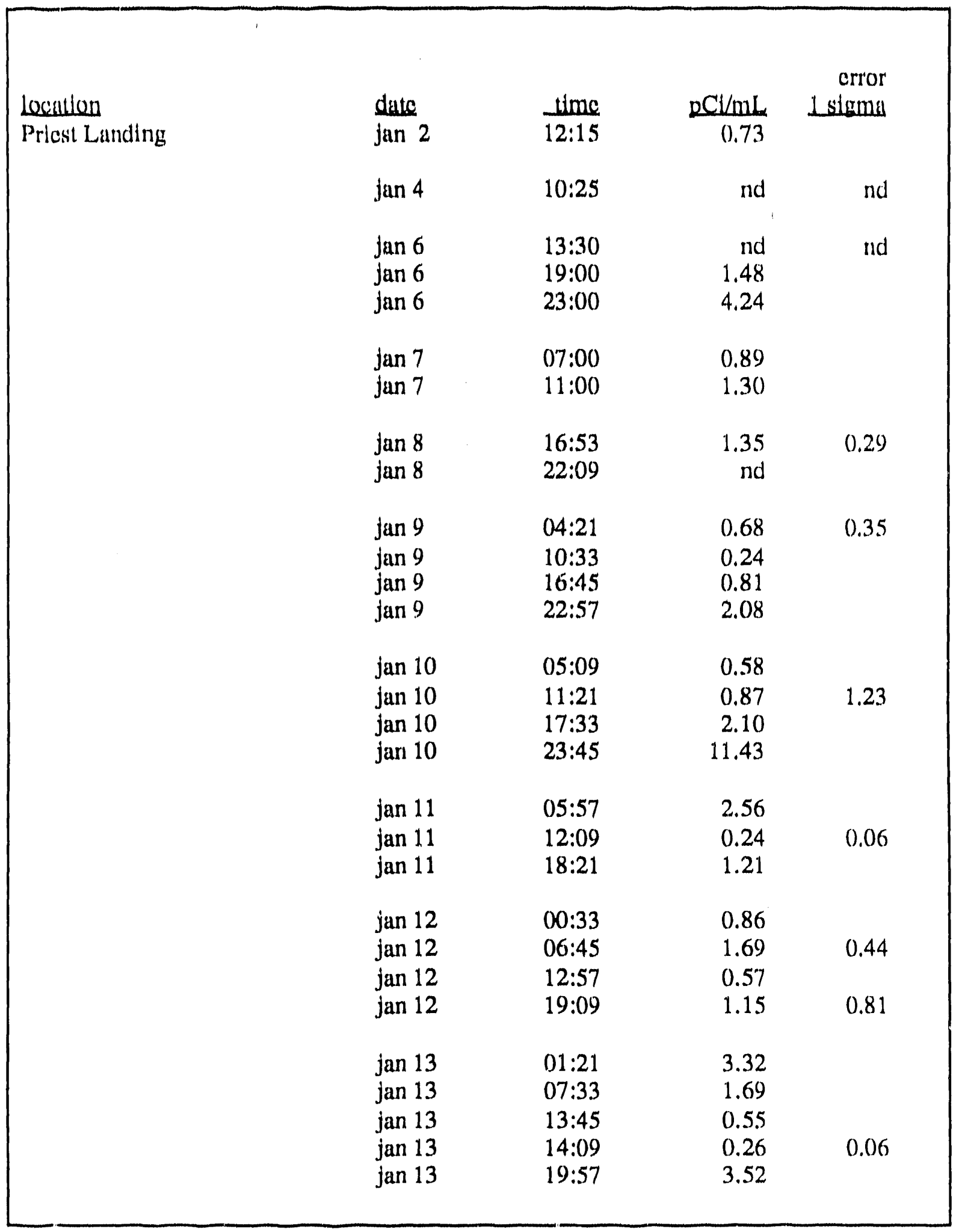


Table B11. Estuarine study (Page 5 of 6 )

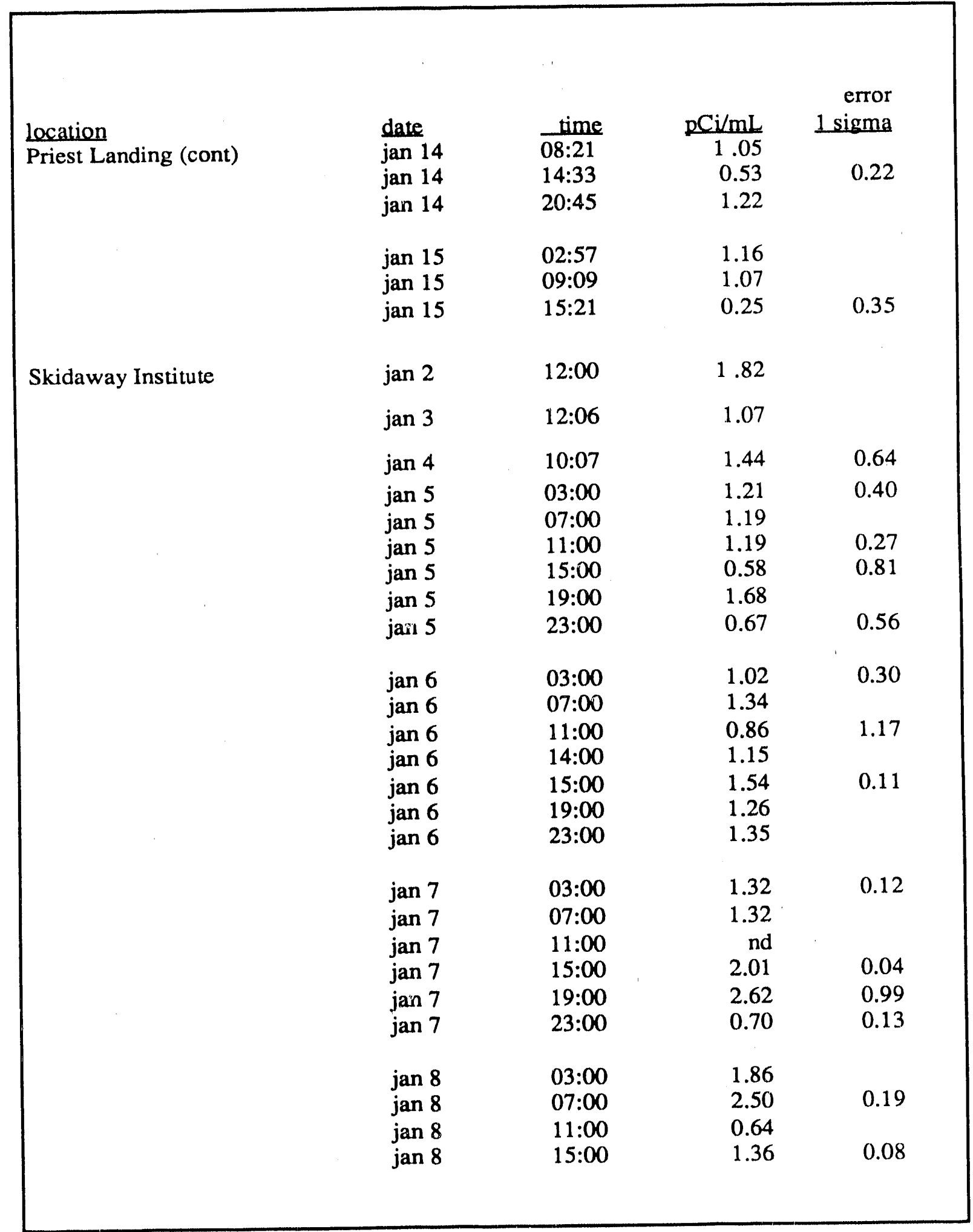


Table B11. Estuarine study (Page 6 of 6)

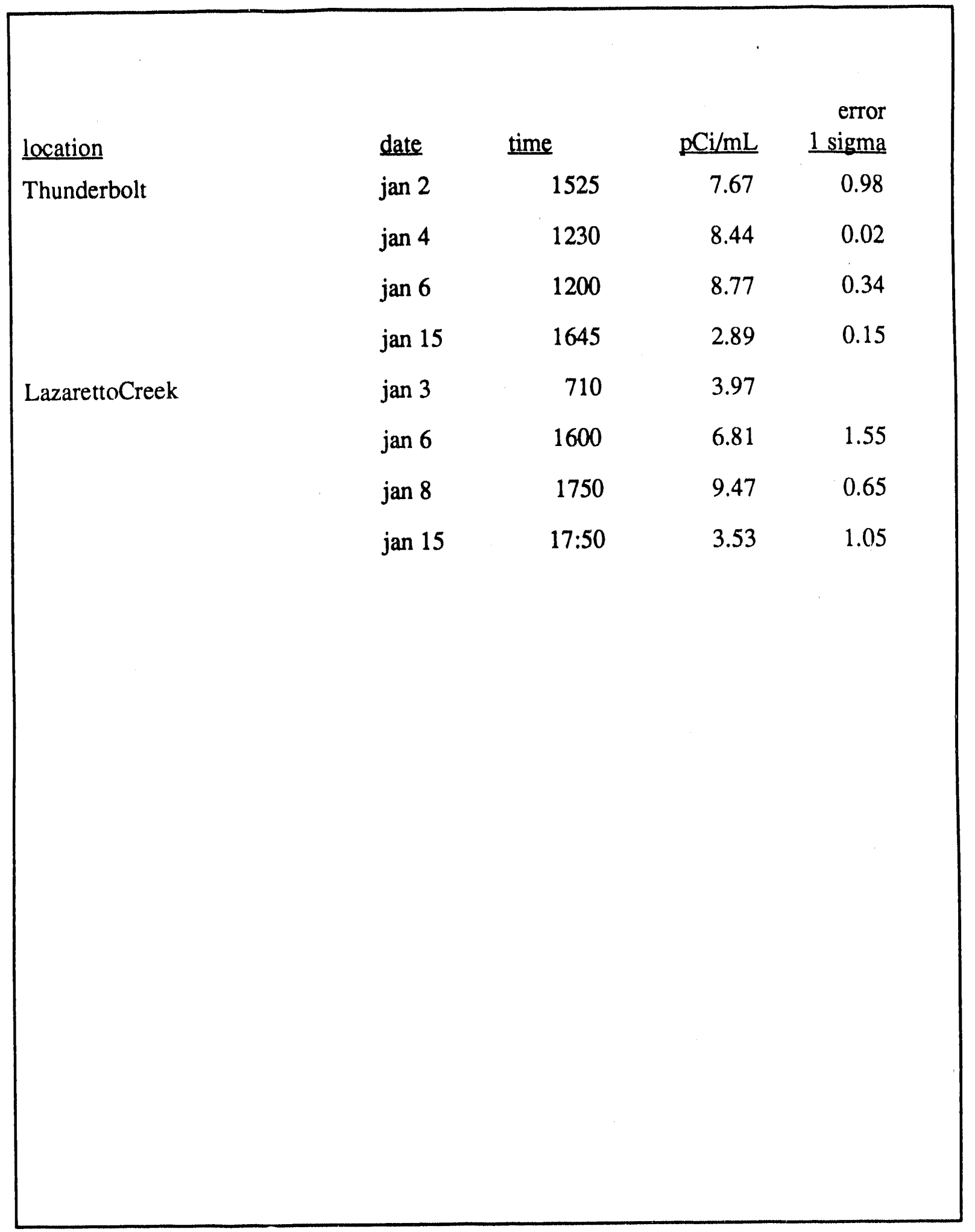


Table B12. Estuarine survey

location

Estuary South

(sweep)

EstuaryNorth

(sweep) date time

jan $3 \quad 1125$

jan $3 \quad 1140$

jan $3 \quad 1146$

jan $3 \quad 1206$

jan $3 \quad 1212$

jan $3 \quad 1230$

jan $3 \quad 1247$

jan $3 \quad 1253$

jan 3

jan 3

1259

1620

Savannah River (sweep)

jan 3

jan 3

jan 3

jan 3

jan 3

jan 3

jan 3

jan 3

jan 3

jan 3

jan 3

jan 3
1335

1345

1357

1403

1418

1423

1430

1440

1500

1503

1518

1525 error

$\mathrm{pCi} / \mathrm{mL} \quad 1$ sigma nd

nd

0.53

0.39

nd

1.38

7.48

0.59

11.52

0.36

11.76

2.00

12.85

0.27

13.53

0.94

25.69

0.86

26.72

0.59

25.19

0.66

23.00

14.57

0.35

11.85

13.12

8.96

0.87

0.15

0.85

0.82

0.78 
Table B 13. Tritium concentrations measured in the Savannah River (values are calculated daily averages of hourly mcasured concentrations).

_Daily Average Measured Concentrations ( $\mathrm{pCi} / \mathrm{mL}$ )_

Date

$\begin{array}{ll}\text { Hwy 301 } & \text { Beaufort-Jasper } \\ \text { Bridge } & \text { Becks Ferry }\end{array}$

$\operatorname{Dec} 22$

2.4

$\operatorname{Dec} 23$

3.0

$\operatorname{Dec} 24$

2.6

Dec 25

3.8

Dec 26

36.9

Dec 27

56.3

Dec 28

55.5

Dec 29

45.7

Dec 30

33.3

Dec 31

22.2

15.4

9.5

9.6

6.6

5.0

4.0

22.0

$\operatorname{Jan} 2$

Jan 3

$\operatorname{Jan} 4$

$\operatorname{Jan} 5$

$\operatorname{Jan} 6$

$\operatorname{Jan} 7$

$\operatorname{Jan} 8$

5.1

7.0

$\operatorname{Jan} 9$

6.5

3.8

45.8

49.8

Jan 10

4.2

43.8

Jan 11

3.8

32.3

Jan 12

2.6

22.6

Jan 13

Jan 14

Jan 15

3.8

14.3

9.6

6.8

6.5

6.0

4.0

4.8

6.0

5.3

3.3

3.1

3.8

2.6

3.1 
Table B14. Savannah River transport of K-Reactor tritium based on results for the Highway 301 bridge*.

Date

$\operatorname{Dec} 22,1991$

$\operatorname{Dec} 23$

Dec 24

Dec 25

Dec 26

$\operatorname{Dec} 27$

Dec 28

$\operatorname{Dec} 29$

Dec 30

Dec 31

Jan 1, 1992

Jan 2

$\operatorname{Jan} 3$

$\operatorname{Jan} 4$

$\operatorname{Jan} 5$

$\operatorname{Jan} 6$

$\operatorname{Jan} 7$

Jan 8

Jan 9

Jan 10

Jan 11

Jan 12

Jan 13

Jan 14

Jan 15
Estimated River

Flow, Hwy 301

(cfs)

8981

6985

6876

7135

7506

7698

7929

8709

8923

9101

9113

8894

8451

8590

8007

8208

7824

9127

9388

8527

7857

8361

8327

8110

9681
Daily

Transport

(Ci)

0

0

0

12

621

1000

1020

908

659

425

343

139

134

74

37

18

38

87

78

15

21

14

0

14

17
Cumulative

Transport

(Ci)

*The 5-year average tritium concentration at $\mathrm{Hwy} 301$ is $3.1 \mathrm{pCi} / \mathrm{mL}$. 
This page intentionally left blank 
Appendix C

Quality Assurance 
This page intentionally left blank 


\section{Quality Assurance}

Quality control charts showing the counting results of spike and blank samples prepared with each batch of samples are shown in Figures $\mathrm{C} 2$ and $\mathrm{C} 3$ of Appendix C. The photo-multiplier tube (PMT) in the Tri-Carb counter failed on January 15 (after blank number 149 and spike number 121). All samples collected prior to the failure had at least one count completed before the PMT failure. After a replacement PMT was installed, greater variability in the blank count rates was apparent, however, the average blank count rate remained the same, within counting uncertainty. Blank number 191 (196 dpm) was excluded from the running average (the line shown in Figure C3, Appendix C).

If the quench correction had no uncertainty associated with it, the expected spike activity would be $6613 \mathrm{dpm}$ (the solid line in Figure C2, Appendix C). This is based on the NIST certified value of the standard. Prior to the PMT failure, recovery of the spike (dpm measured/dpm expected) averaged 1.04, implying that activity in the water samples may have been overestimated by $4 \%$. After the PMT was replaced, spike recovery was significantly higher: Figure $\mathrm{C} 2$ shows that the measured sample activity may have been overestimated by up to $20 \%$. However, counting uncertainties (Fig. C1) were greater than $20 \%$ for samples counted after the PMT replacement. This was due to the low tritium concentrations at that time. The large counting uncertainties effectively masked the bias in the quench correction. 
This page intentionally left blank 


\section{Predicted Counting Statistics in LSC Analysis of Tritium in Water}

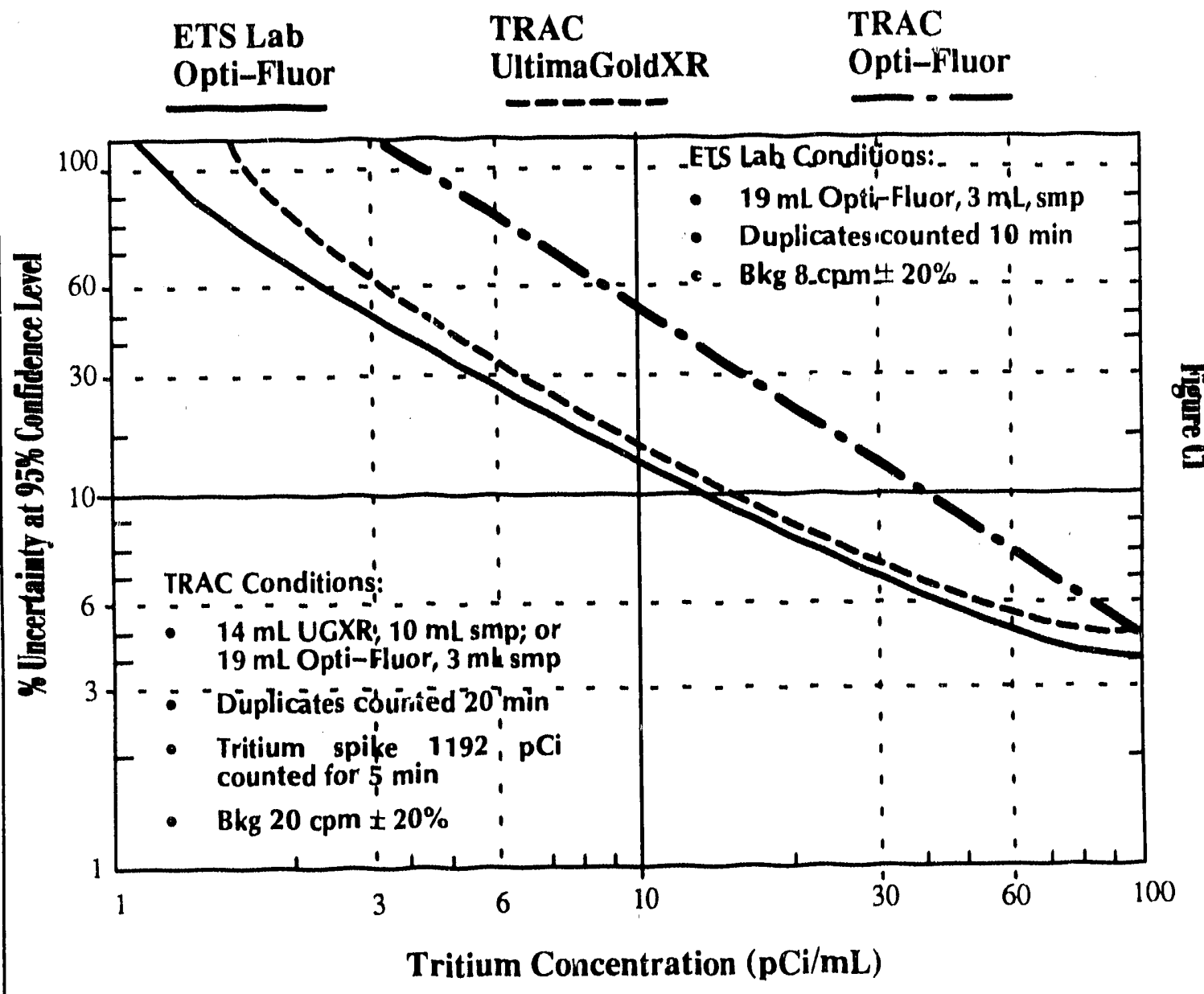

Figure C1. Typical uncertainties in the LSC 


\section{Spike Results}

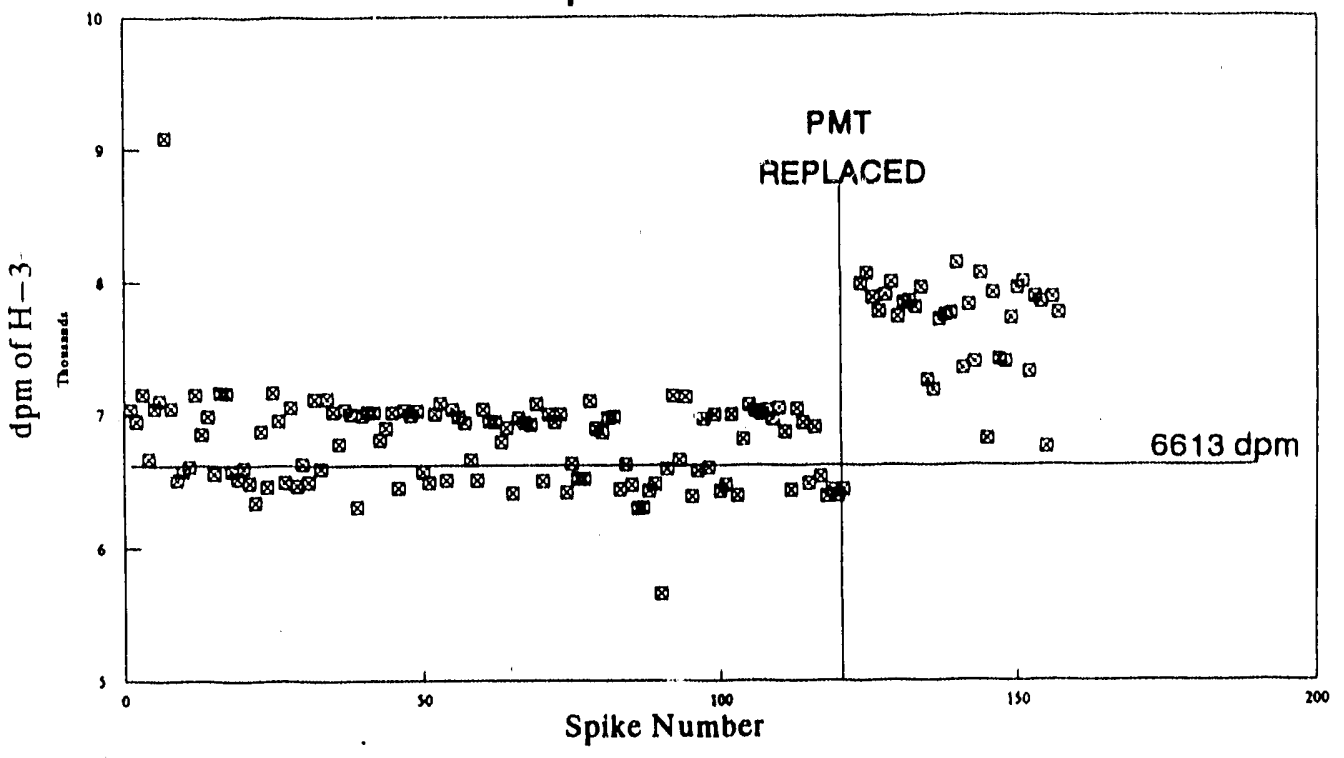

Figure C2. Spike results 


\section{Blank Results}

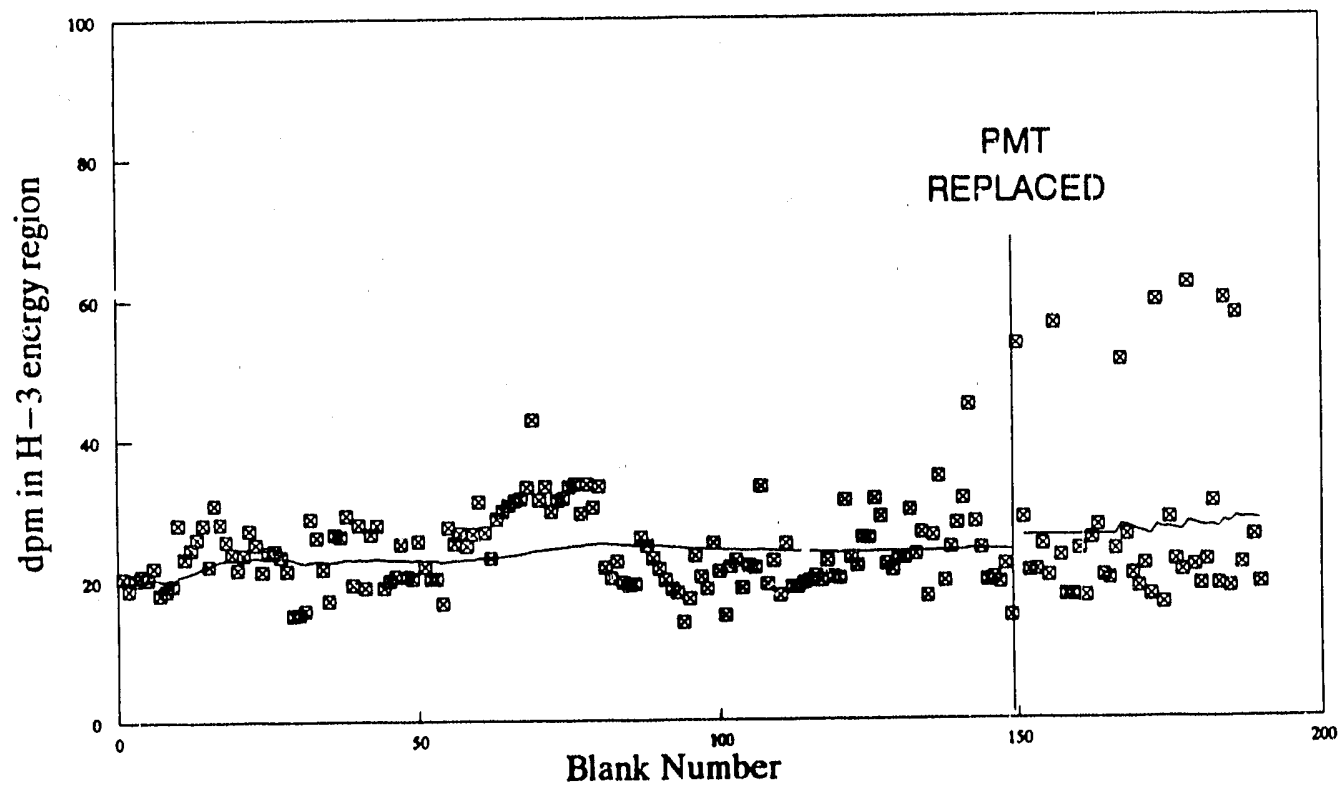

Figure C3. Blank results 
This page inientionally left blank 
Appendix D

Tritium Transport in the Savannah River 
This page intentionally left blank 


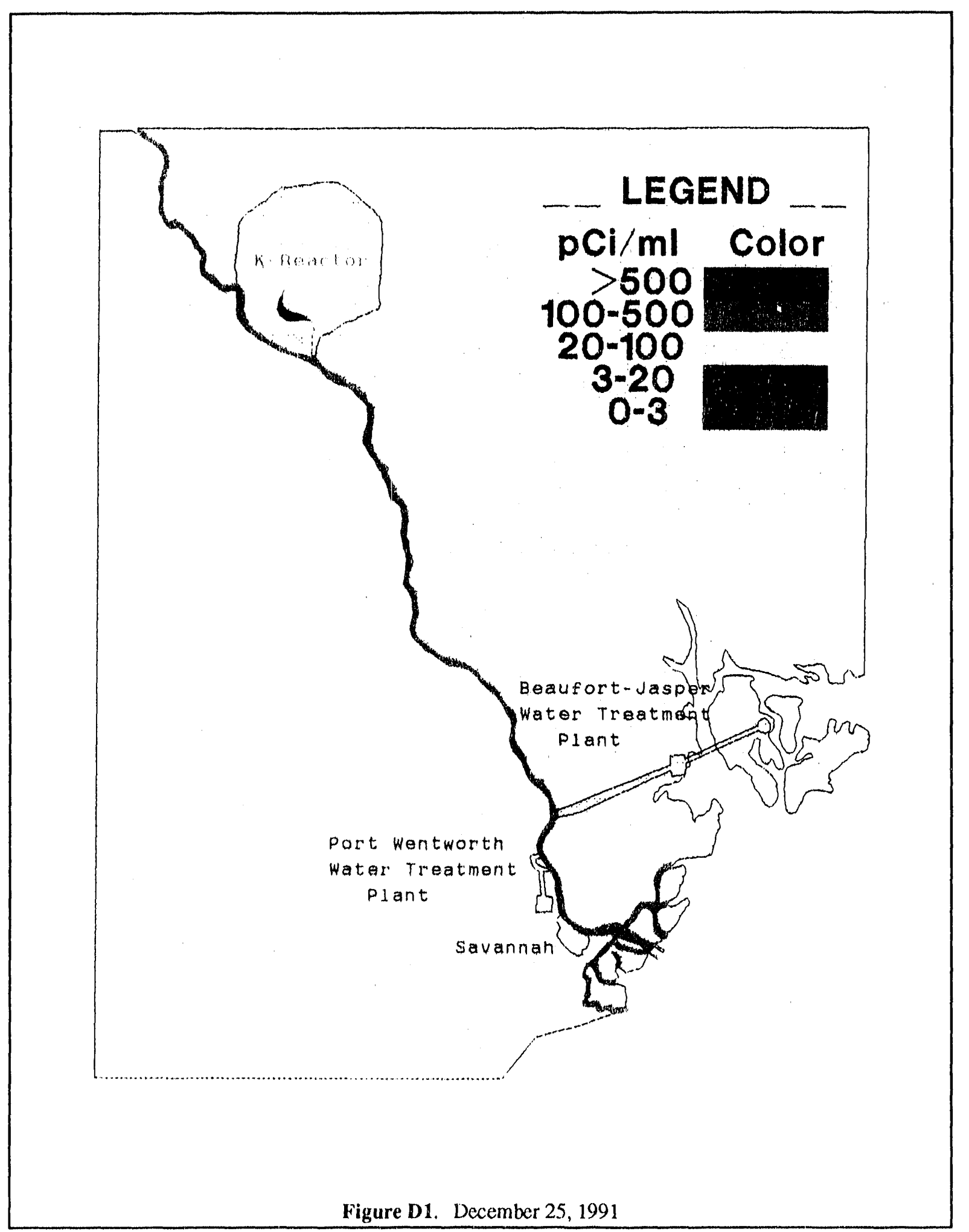




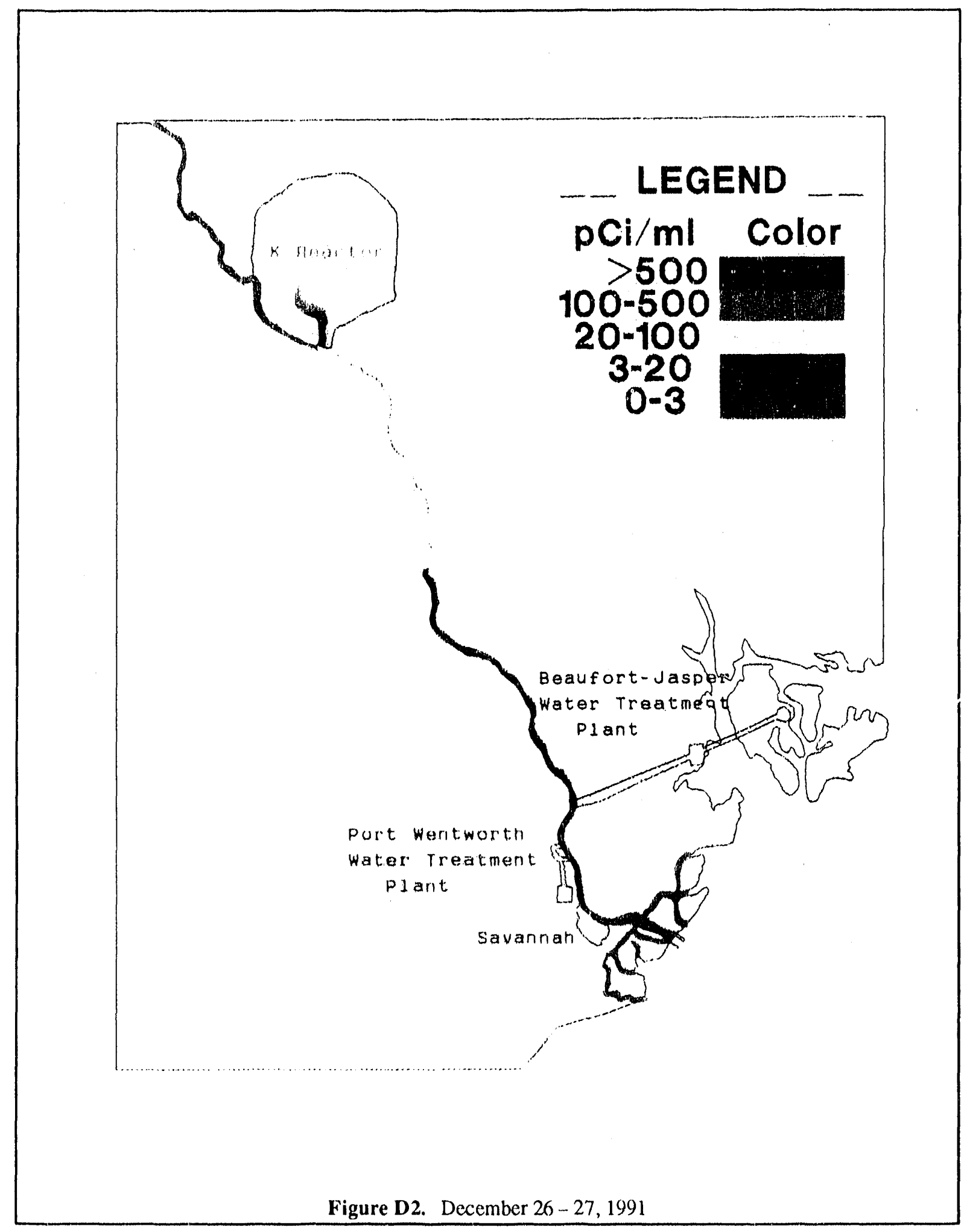




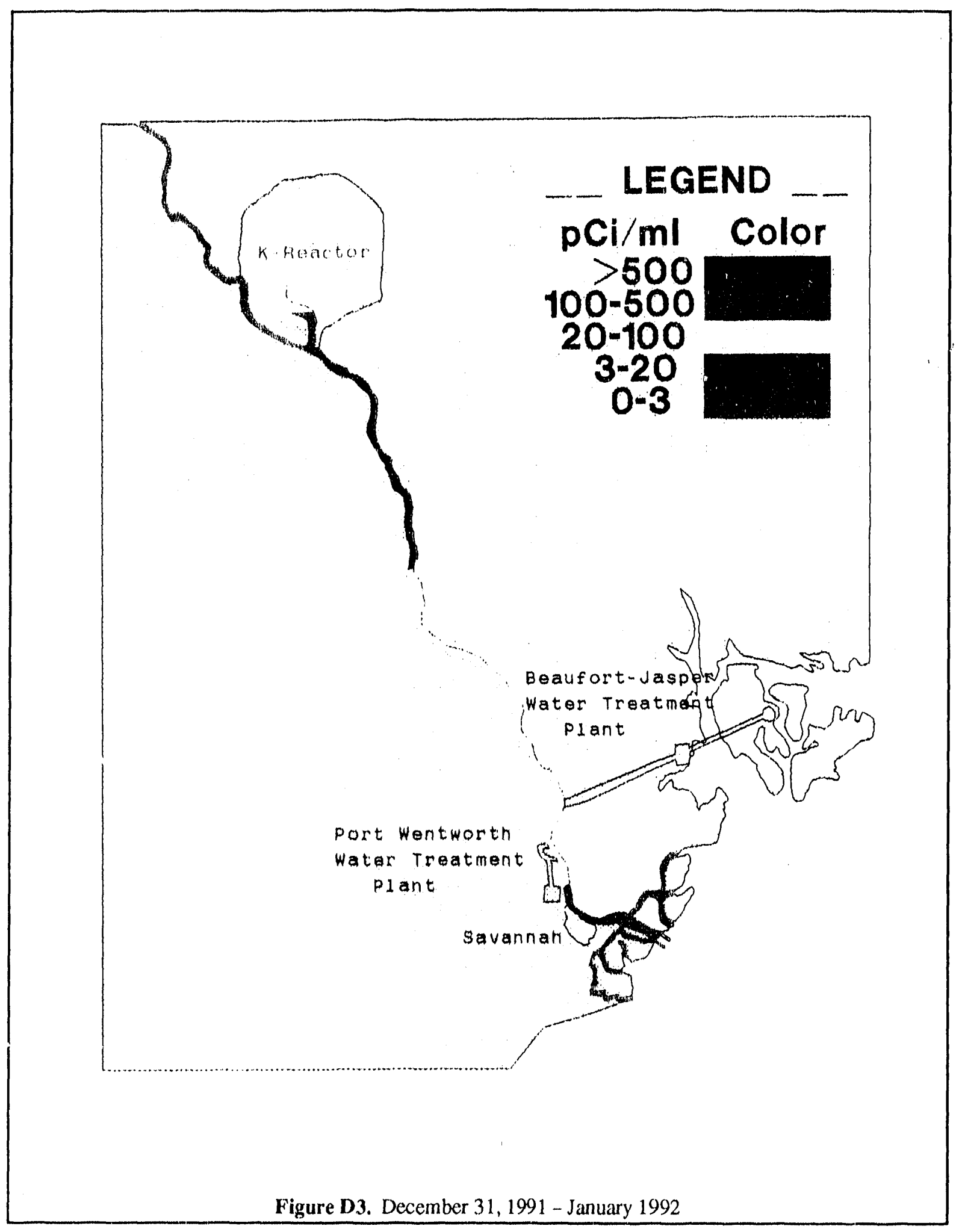




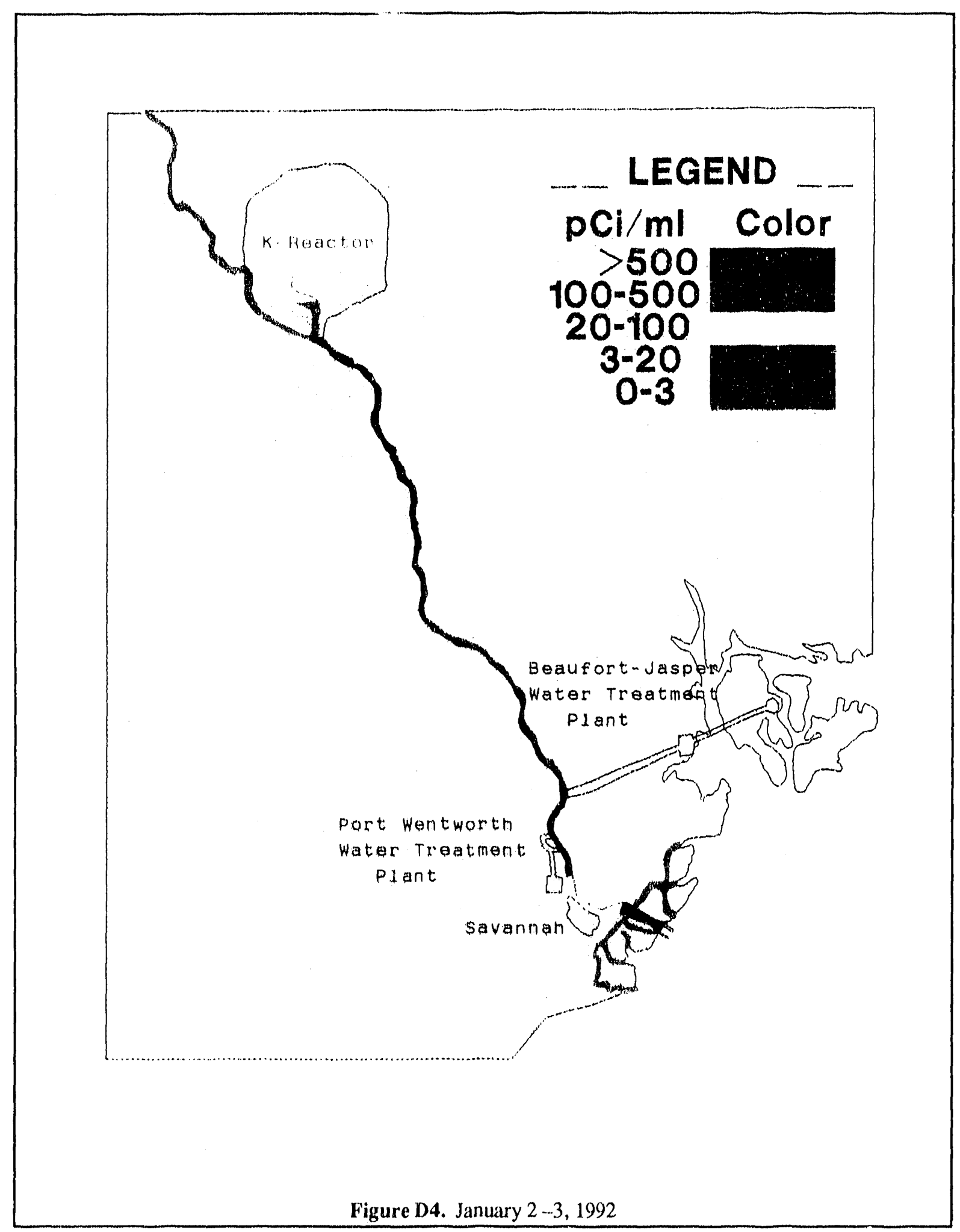




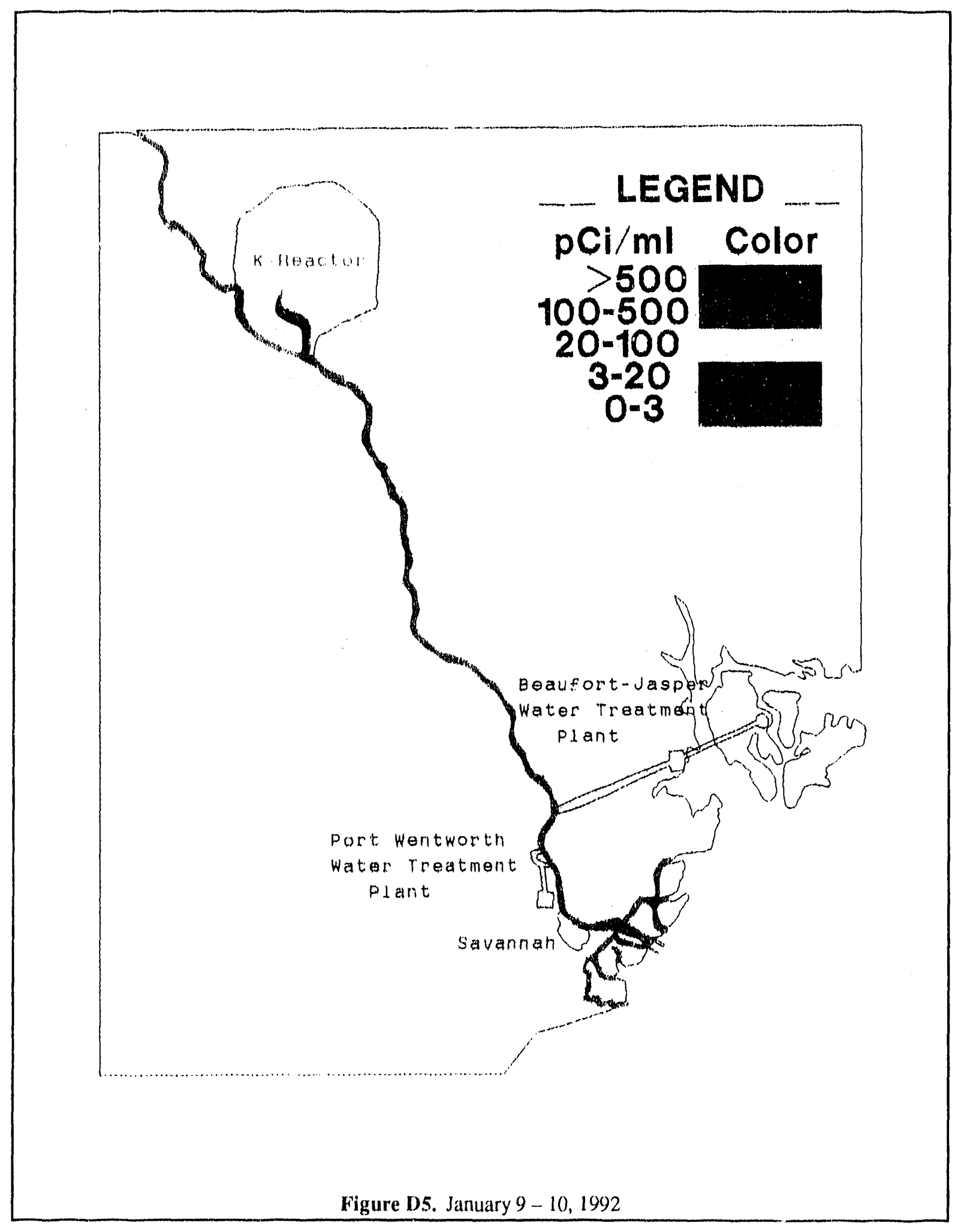



OF THE K-REACTOR AQUEOUS TRITIUM RELEASE OF DECEMBER 1991 (U)

\section{DISTRIBUTION}

R.P. Addis, 773A

D.M. Beals, 735A

R.T. Begley, 773A

A.L. Boni, 773A

W.J. Brumley, 703A

J.R. Cadieux, 735-7A

R.R. Campbell, 703A

W.H. Carlton, 773A

T.V. Crawford, 773A

L. Davis, 703-41A

T.S DeHart, 735A

P. Dickson, 773A

D.L. Dunn, 735A

A.J. Garrett, 773A

G. Hall, 735A

J.E. Halverson, 735A

D.M. Hamby, 773A

D.W. Hayes, 773A

T.F. Heenan, 703A

J.D. Heffner, 735A

J.N. Herrmann, 703A

C.H. Hunter, 773A

M.V. Kantelo, 735A

J.A. Lazzaro, 742-3A

R. Lorenz, 735-16A

F.R. McCoy, 703-41A

D.B. Moore-Shedrow, 773A

L.M. Papouchado, 773A

W.C. Reinig, 742A

P.D. Rice, 703A

J.S. Roberts, 742A

S.J. Smith, 704K

D.A. Stevenson, 735A

R.W. Taylor, 735A

A.L. Towns, 773-41A

R.A. Walker, 703A

D. Woodward, 735-15A

S.R. Wright, 703-41A

R.H. Young, 735-11A

D.N. Zweifel, 703-41A

EDG Files (10)

SRL Files (4) 

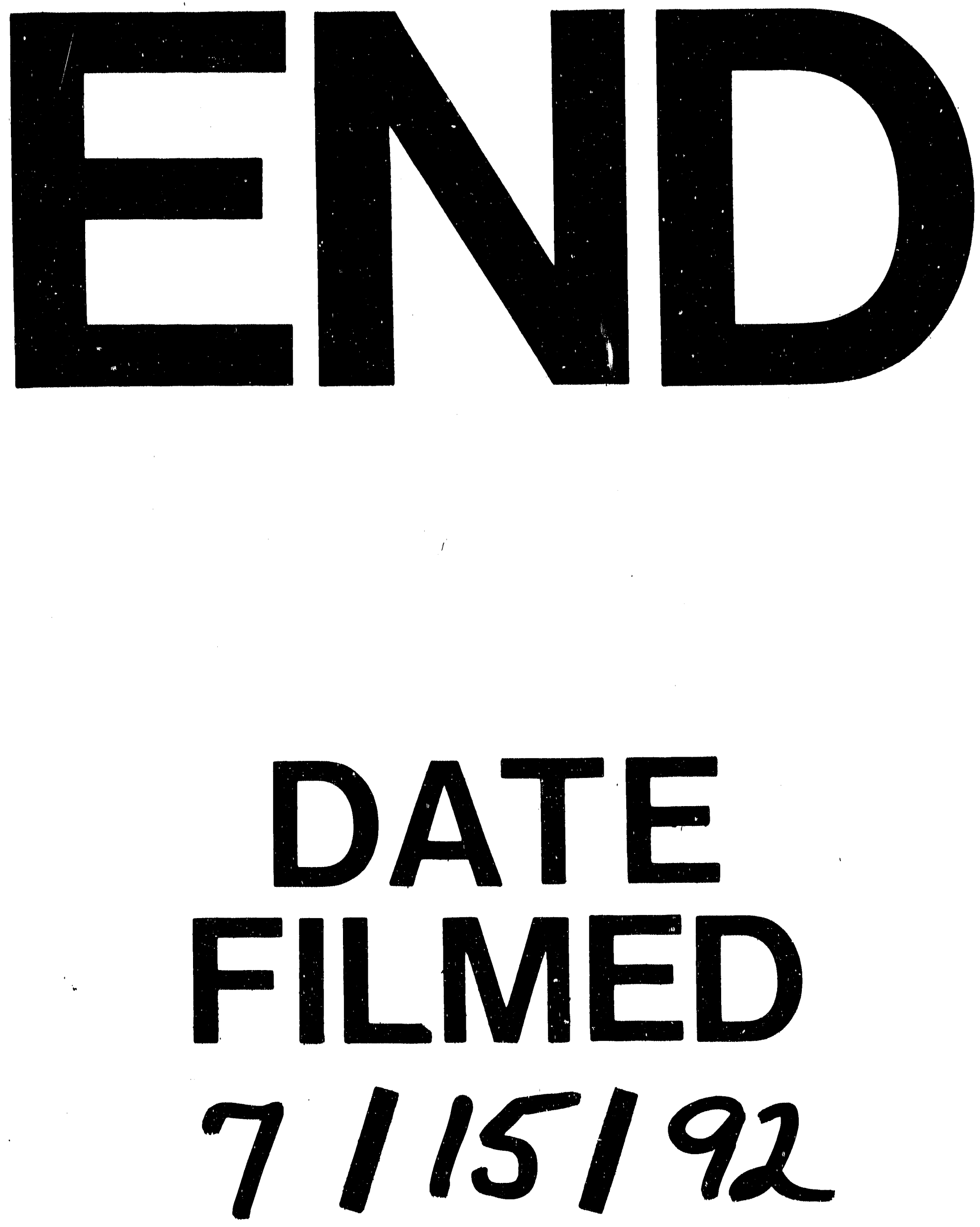
